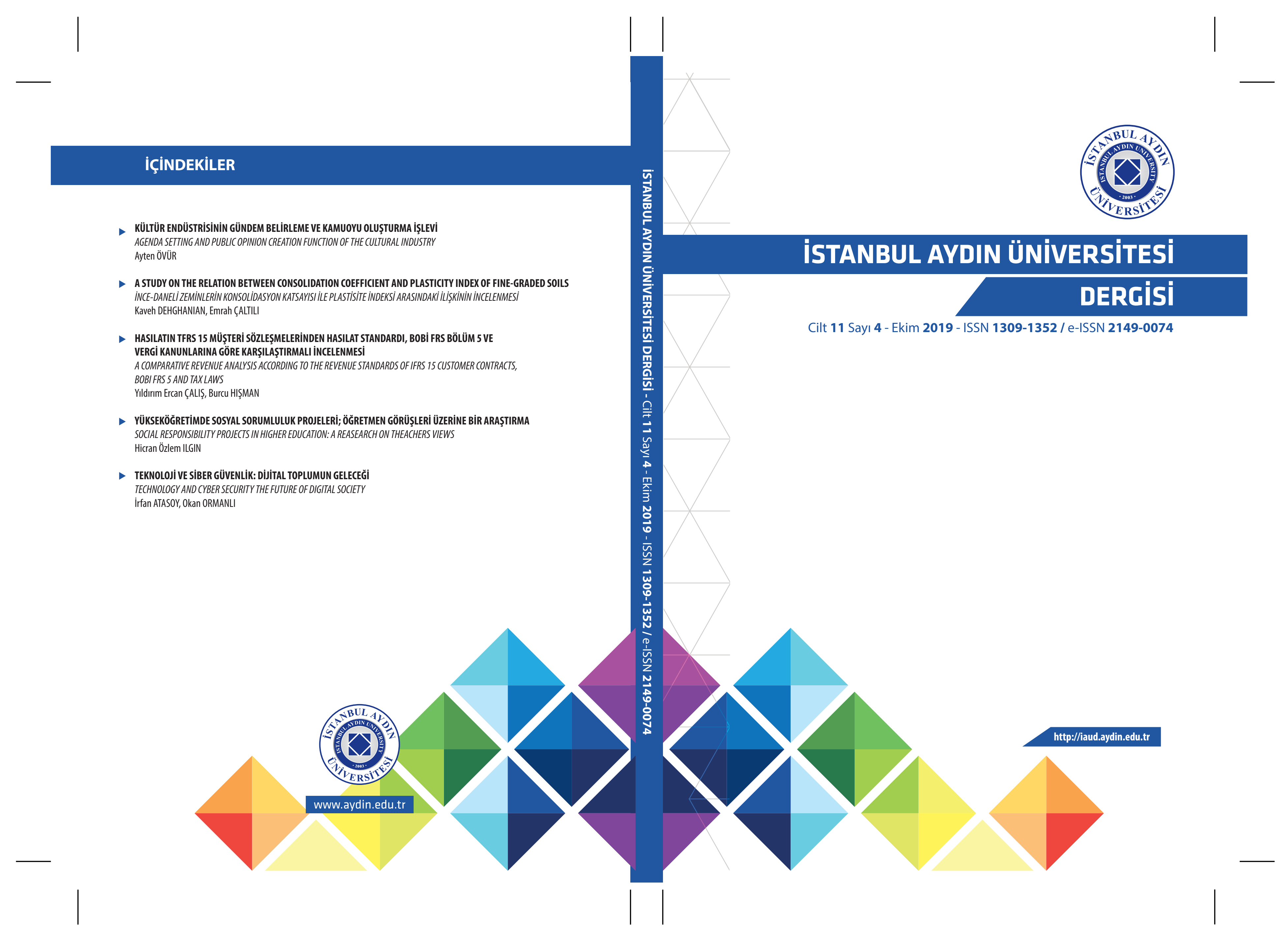




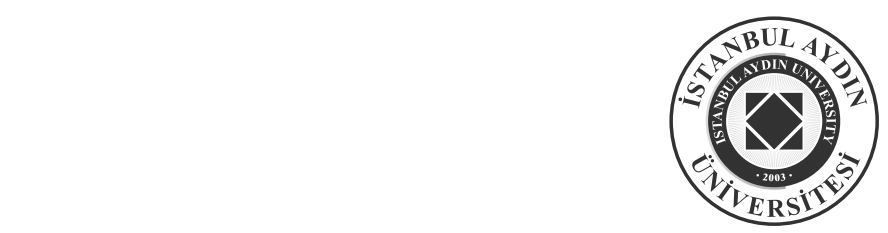

ISTANBUL AYDIN ÜNIVERSITESI

DERGISI

\title{
EKIM 2019
}

ISSN: 1309-1352

e-ISSN: 2149-0074

\section{CiLT 11 - SAYI 4}

DOI: 10.17932/IAU.IAUD.m.13091352.2019.4/44

\author{
İişim \\ http://iaud.aydin.edu.tr/2019-ekim-cilt-11-sayi-4/

\section{Editör} \\ Doç. Dr. Deniz YENGiN
}

\section{Editör Yardımcıları}

Arş. Gör. Tamer BAYRAK

Arş. Gör. İrem YENICELER

iaud.aydin.edu.tr 



\section{İSTANBUL AYDIN ÜNIVERSITESİ DERGISİ \\ (ISSN: 1309-1352) - (e-ISSN: 2149-0074)}

\section{Odak ve Kapsam}

İstanbul Aydın Üniversitesi Dergisi, bilimin rehberliğinde dünyaya açılmak, içinde bulunduğu topluma ulaşabilmek, onların değişen ve gelişen taleplerine öncülük etmek için araştırmacıların özün bilimsel makalelerini uluslararası yayıncılık ilkeleri doğrultusunda yayımlamak amacını güder. İstanbul Aydın Üniversitesi Dergisi, İstanbul Aydın Üniversitesi’nin yayın organıdır. Çeşitli konularda özgün Türkçe ve İngilizce bilimsel makalelerin yayımlandığı bir süreli yayındır. İstanbul Aydın Üniversitesi Dergisi hakemli bir dergidir ve 2009 yılından beri yayımlanmaktadır.

İstanbul Aydın Üniversitesi Dergisinde (İAÜD); uygulamalı iletişim, yeni medya, sosyal politika ve çalışma ilişkileri, grafik tasarımı, siyaset bilimi ve uluslararası ilişkiler, hukuk, davranış bilimleri, tarih, sanat tarihi, arkeoloji, Türk dili ve edebiyat1, eğitim bilimleri, uzaktan eğitim, iletişim bilimleri, güzel sanatlar, yabancı diller ve edebiyatları, dil bilim ve bunun gibi sosyal bilimlerdeki ilgili alanlarında bilimsel çalışmalar kapsamında eserler yayınlanmaktadır.

\section{İndeks ve Özet Bilgisi}

EBSCO Academic Search Complete

Academic Search Ultimate and One Belt

One Road Reference Source

DOAJ

Dergipark

\section{Yayıncı}

İstanbul Aydın Üniversitesi, Türkiye

\section{Değerlendirme Süreci}

İstanbul Aydın Üniversitesi Dergisine gönderilen makaleler, iki hakem tarafından değerlendirilir. Hakemlerden birinin olumsuz, diğerinin olumlu görüş bildirmesi durumunda Yayın Kurulu hakem raporlarını inceleyerek makalenin işlem sürecini üçüncü bir hakeme gönderme yönünde ya da yazarına iade etme şeklinde belirler. Makalenin yayımlanabilmesi için en az iki hakemin olumlu görüş bildirmesi gerekir. Makaleler Turnitin ve/veya iThenticate intihal yazılımları ile kontrol edilmektedir. Hakemlerin raporları tamamlandıktan sonra yazılar, Yayın Kurulu'nun onaylaması durumunda yayıma hazır hale gelir ve kabul sırası dikkate alınarak uygun görülen sayıda yayımlanır.

\section{Yayın Sıklığı}

İstanbul Aydın Üniversitesi Dergisi Ocak, Nisan, Temmuz, Ekim olmak üzere yılda 4 kez yayımlanır. Dergiye belli bir sayı için makale kabul edilmemektedir. Yazarlar istediği zaman makalesini gönderebilir. Değerlendirme süreci tamamlanan makaleler geliş tarihi dikkate alınarak yayımlanır.

\section{Açık Erişim Politikası}

Açık erişimin bilginin evrensel kullanımını artırarak, insanlık için yararlı sonuçlar doğuracağı düşüncesinden hareketle, İstanbul Aydın Üniversitesi Dergisi Açık Erişim politikasını benimsemiştir. Dergi, yazarlardan devraldığı ve yayımladığı içerikle ilgili telif haklarından, bilimsel içeriğe evrensel 
Açık Erişimin (Open Access) desteklenmesi ve geliştirilmesine katkıda bulunmak amacıyla, bilinen standartlarda kaynak olarak gösterilmesi koşuluyla, ticari kullanım amacı ve içerik değişikliği dışında kalan tüm kullanım (bağlantı verme, kopyalama, baskı alma, herhangi bir fiziksel ortamda çoğaltma ve dağıtma vb.) haklarını bedelsiz kullanıma sunmaktadır. İçeriğin ticari amaçlı kullanımı için yayınevinden yazılı izin alınması gereklidir.

\section{Yayın Ücreti}

Dergi için her hangi bir ücret talep edilmemektedir. Ayrıca kabul edilen bütün makaleler ücretsiz yayımlanmaktadır.

\section{Araştırma ve Yayın Etiği İlkeleri}

İAÜD'ye gönderilen bilimsel yazılarda, Yükseköğretim Kurumları Bilimsel Araştırma ve Yayın Etiği ile ilişkili yönergeler, ICMJE (International Committee of Medical Journal Editors) önerileri ve COPE (Committee on Publication Ethics)'un Editör ve Yazarlar için Uluslararası Standartları dikkate alınmalıdır. İntihal, verilerde sahtecilik ya da yanıltmacılık, yayın tekrarı, bölerek yayınlama ve araştırmaya katkısı olmayan kişilerin yazarlar arasında yer alması etik kurallar dahilinde kabul edilemez uygulamalardır. $\mathrm{Bu}$ ve benzeri uygulamalarla ilişkili herhangi etik bir usulsüzlük durumunda gerekli yasal işlemler yapılacaktır.

a) İntihal: Başkalarının özgün fikirlerini, metotlarını, verilerini veya eserlerini bilimsel kurallara uygun biçimde atıf yapmadan kısmen veya tamamen kendi eseri gibi göstermek, intihal kapsamında ele alınmaktadır. İntihalden kaçınmak için yazarlar bilimsel kurallara uygun bir şekilde atıf yapmalı ve araştırmaları içerisinde yer alan tüm bilimsel yazılara ait kaynak gösterimine dikkat etmelidirler.

b) Veride Sahtecilik: Bilimsel araştırmalarda gerçekte var olmayan ya da değişikliğe uğratılmış verileri kullanmak, veride sahtecilik kapsamında ele alınmaktadır. Yazarlar verilerini etik kurallar dahilinde toplayarak, süreç içerisinde geçerlik ve güvenirliği etkileyecek bir değişikliğe maruz birakmadan analiz etmelidirler.

c) Çarpıtma: Araştırmadan elde edilen kayıtları ya da verileri değiştirmek, araştırmada kullanılmayan cihaz veya materyalleri kullanılmış gibi göstermek, destek alınan kişi ve kuruluşların çıkarları doğrultusunda araştırma sonuçlarını değiştirmek ya da şekillendirmek, çarpıtma kapsamında ele alınmaktadır. Yazarlar araştırma süreci ile ilişkili verdikleri bilgilerde dürüst, objektif ve şeffaf olmalıdırlar. Etik kuralları ihlal etmekten kaçınmalıdırlar.

d) Yayın Tekrarı: Aynı yayını, yapılmış olan önceki yayınlara atıf yapmaksızın ayrı yayınlar olarak sunmak, yayın tekrarı kapsamında ele alınmaktadır. Değerlendirilmek üzere gönderilen yayınların daha önce başka bir yerde yayımlanması ya da değerlendirme sürecinde olması ile ilişkili sorumluluk tamamen yazarlara aittir. Yazarlar tekrardan kaçınmalı, özgün ve orijinal araştırmalarını göndermeye özen göstermelidirler.

e) Bölerek Yayınlama: Bir araştırmanın sonuçlarını, araştırmanın bütünlüğünü bozacak şekilde ve uygun olmayan biçimde parçalara ayırıp birden fazla sayıda yayımlayarak bu yayınları ayrı yayınlar olarak sunmak, bölerek yayınlama kapsamında ele alınmaktadır. Yazarlar araştırma bütünlüğünü göz önünde bulundurmalı ve sonuçları etkileyecek bölmelerden kaçınmalıdırlar. 
f) Yazarlık: Araştırmaya katkısı olmayan kişileri yazarlar arasına dâhil etmek ya da katkısı olan kişileri dâhil etmemek, haksız yazarlık kapsamında ele alınmaktadır. Araştırmanın planlanması, tasarımı, verilerin toplanması, analiz edilmesi, değerlendirilmesi, araştırmanın yayına hazırlanması ve son halinin ortaya koyulması aşamalarına tüm yazarlar yeterli düzeyde katkı sağlamış olmalıdırlar.

\section{İntihal Politikası}

Gönderilen tüm makaleler kontrol taramasından geçmek zorundadır ve iThenticate ve/veya Turnitin (Advanced Plagiarism Dectection Software) aracılığıyla kontrol edilmektedir.

\section{Telif Hakkı}

Telif hakkı; bilimsel olarak hazırlanmış makalelerin ayrıntılı bir şekilde korunmasını amaçlar. Yazarın haklarını korumak ve yeniden basma ya da yayınlanan araştırmanın diğer kullanım izinlerini düzenlemek için İAÜD, yazarların makalelerini yayınlanmaya hazır olduğunda tüm haklarını imzalamaları gereken bir telif hakkı formuna sahiptir.

İAÜD, yazarların telif hakkını kısıtlama olmaksızın kullanmalarına izin verir ve yayınlama haklarını kısıtlama olmadan saklar. Gönderilen kağıtların patent veya patent başvurusu ile korunmayan hiçbir özel materyal içermediği varsayılmıştır. Teknik içeriğe ve tescilli materyalin korunmasına ilişkin sorumluluk yalnızca yazara ve kurumlara aittir ve İAÜD veya Yayın Kurulunun sorumluluğunda değildir. Başlıca yazar, makalenin diğer tüm yazarlar tarafından görülmesini sağlamaktan sorumludur. Gönderilmeden önce makalede telif hakkıyla korunan materyallerin kullanımı için gerekli tüm telif hakkı izinlerini almak yazarın sorumluluğundadır.

\section{Yazar olarak haklarım nelerdir?}

Yetki olarak haklarınızı belirlemek için gönderdiğiniz veya yayınladığınız derginin politikasını kontrol etmeniz önemlidir. İAÜD’nin standart politikaları aşağıdaki yeniden kullanım haklarına izin verir:

İAÜD; makalelerin yazarlar tarafından telif hakkı kısıtlaması olmaksızın kullanmasına izin verir.

Yayınlanan makaleyi, kendi eğitim ihtiyaçlarınız için veya araştırma kaynağınıza, bu arzın ticari amaçlarla kullanılmaması koşuluyla bireysel olarak sağlamak için kullanabilirsiniz.

Yayınlanan makaleyi İAÜD’nin izni olmadan bir web sitesinde yayınlayamazsınız.

\section{Makale Çağrısı}

İAÜD, farklı alanlardan gelen akademisyen ve profesyonelleri "sosyal bilimler"le ilgili bu konulardaki farklı görüşlerini tartışmak üzere bir araya getirmeyi amaçlamaktadır.

\section{İAÜD'ün Ana Konuları}

- Medya çalışmaları

- İktisat ve işletme çalışmaları

- Ekonomi

- Mimari

- Dijital kültür

- İletişim çalışmaları 
- Reklamcilık

- Halkla ilişkiler

- Sosyal bilimler

- Sağllk iletişimi

- Sosyoloji

- Eğitim bilimleri

- İnsan kaynakları yönetimi

- Televizyon ve sinema

- Hukuk

- Türk dili ve edebiyatı

\section{Yayın Dili}

Türkçe ve İngilizce

\section{Makale Gönderimi}

Makaleler elektronik ortamda iaud@aydin.edu.tr adresine gönderilmelidir.

\section{İletişim}

İstanbul Aydın Üniversitesi

İstanbul - Turkey

e-mail: iaud@aydin.edu.tr

Tel: +902124441428 


\section{JOURNAL OF İSTANBUL AYDIN UNIVERSITY (İAÜD) \\ (ISSN: 1309-1352) - (e-ISSN: 2149-0074)}

\section{Focus and Scope}

The aim of İAÜD is to create a source for academics and scientists who are doing research in the media, technology and communication that feature formally well-written quality works. And also create a source that will contribute and help develop the fields of study. Accordingly, İAÜD's intentions are on publishing articles and scientific works which are guided by a scientific quality sensibility. In this context, İÄ̈ is qualified as an "international peer-reviewed journal". It is a peerreviewed international journal published four times a year.

\section{INDEX}

EBSCO Academic Search Complete

Academic Search Ultimate and One Belt

One Road Reference Source

DOAJ

Dergipark

\section{Publisher}

İstanbul Aydın University, TURKEY

\section{Peer Review Process}

The editorial board peruses the submitted material with regard to both form and content before sending it on to referees. They may also consider the views of the advisory board. After the deliberation of the editorial board, submitted material is sent to two referees. In order for any material to be published, at least two of the referees must approve it. The revision and improvement demanded by the referees must be implemented in order for an article to be published. Authors are informed within three months about the decision regarding the publication of their material. All the papers are controlled academically with the TURNITIN or/and iThenticate program.

\section{Open Access Policy}

İAÜD adopted a policy of providing open access.

This is an open access journal which means that all content is freely available without charge to the user or his/her institution. Users are allowed to read, download, copy, distribute, print, search, or link to the full texts of the articles in this journal without asking prior permission from the publisher or the author. This is in accordance with the BOAI definition of open access.

\section{Publication Charge}

No publication charge or article processing charge is required. All accepted manuscripts will be published free of cost. 


\section{Principles of Research and Publication Ethics}

In scientific papers sent to IAUD, the guidelines related to the Scientific Research and Publication Ethics of Higher Education Institutions, the recommendations of the International Committee of Medical Journal Editors and the International Standards for the Authors and Authors of the Committee should be taken into attention. Plagiarism, forgery in the data, misleading, repetition of publications, divisional publication and individuals who do not contribute to the research are among the authors are unacceptable practices within the ethical rules. Legal actions will be taken in case of any ethical irregularity related to this and similar practices.

a)Plagiarism: Placing the original ideas, methods, data, or works of others, partly or completely, without making reference to the scientific rules, is dealt with in the context of plagiarism. In order to avoid plagiarism, the authors should refer to the scientific rules in a manner that is appropriate and should pay attention to the references of all scientific papers in their research.

b)Forgery of Data: The use of data that does not exist or is modified in scientific research is data in the scope of forgery. Authors should analyze their data in accordance with ethical rules and without exposing them to a change in validity and reliability during the process.

c)Detortion: Changing the records or data obtained from the study, showing the devices or materials that are not used in the research as used, changing or shaping the research results according to the interests of the people and organizations that are supported are considered within the scope of distortion. The authors should be honest, objective and transparent in the information they provide in relation to the research process. They should avoid violating the rules of ethics.

d)Repetition: Presenting the same publication as separate publications without referring to the previous publications is considered within the scope of repetition of publications. The responsibility for the publication of the publications submitted for evaluation in another place or in the evaluation process belongs to the authors. The authors should refrain from repeating the original and original research and they should pay attention to submit their original and original research.

e)Divisional Publication: The results of a research are discussed in the scope of dissemination and disseminating the results of the research in a way that disrupts the integrity of the research and disseminating it in more than one way, and publishing these publications as separate publications. The authors should consider the integrity of the research and avoid the divisions that will affect the results.

f)Authorship: The inclusion of people who do not contribute to the research or not to include the people who have contributed is considered within the scope of unfair writing. All authors should have contributed sufficiently to the planning, design, data collection, analysis, evaluation, preparation of the research and finalization of the research.

\section{Publication Ethics}

İAÜD requires all authors to adhere to the ethical standards as prescribed by the Committee on Publication Ethics (COPE) which take privacy issues seriously and is committed to protecting your personal information. 


\section{Plagiarism Policy}

All the papers submitted have to pass through an initial screening and will be checked through the Advanced Plagiarism Dectection Software (CrossCheck by iThenticate)

\section{Copyright}

Copyright aims to protect the specific way the article has been written to describe a scientific research in detail. It is claimed that this is necessary in order to protect author's rights, and to regulate permissions for reprints or other use of the published research. İAÜD have a copyright form which is required authors to sign over all of the rights when their article is ready for publication.

\section{Waiver Policy}

İAÜD do not grants waivers to some authors who are unable to afford manuscript handling fee.

\section{Copyright without Restrictions}

The journal allows the author(s) to hold the copyright without restrictions and will retain publishing rights without restrictions. The submitted papers are assumed to contain no proprietary material unprotected by patent or patent application; responsibility for technical content and for protection of proprietary material rests solely with the author(s) and their organizations and is not the responsibility of the İAÜD or its Editorial Staff. The main (first/corresponding) author is responsible for ensuring that the article has been seen and approved by all the other authors. It is the responsibility of the author to obtain all necessary copyright release permissions for the use of any copyrighted materials in the manuscript prior to the submission.

\section{What are my rights as author?}

It is important to check the policy for the journal to which you are submitting or publishing to establish your rights as

Author. İAÜD's standard policies allow the following re-use rights:

The journal allow the author(s) to hold the copyright without restrictions.

The journal allow the author(s) to obtain publishing rights without restrictions.

You may do whatever you wish with the version of the article you submitted to the journal.

Once the article has been accepted for publication, you may post the accepted version of the article on your own personal website, your department's website or the repository of your institution without any restrictions.

You may not post the accepted version of the article in any repository other than those listed above (i.e. you may not deposit in the repository of another institution or a subject-matter repository) until 12 months after publication of the article in the journal.

You may use the published article for your own teaching needs or to supply on an individual basis to research colleagues, provided that such supply is not for commercial purposes. 
You may use the article in a book authored or edited by you *_at any time after publication in the journal. This does not apply to books where you are contributing a chapter to a book authored or edited by someone else.

You may not post the published article on a website or in a repository without permission from İAÜD.

\section{Call For Papers}

İAÜD will bring together academics and professionals coming from different fields to discuss their differing points of views on these questions related to "social sciences".

\section{Main Topics Of İAÜD}

- Media studies

- Social sciences

- Advertisement

- Applied Studies

- Public Relations

- Communication studies

- Economy and bussiness administration

- Architecture

- Health communication

- Sociology

- Education sciences

- Human recources management

- Television and cinema

- Law

- Turkish language and literature

\section{Language Of İAÜD}

Turkish and English

\section{Article Submission}

Manuscripts should be sent to iaud@aydin.edu.tr

\section{Contact}

İstanbul Aydın University

İstanbul - Turkey

e-mail: iaud@aydin.edu.tr

Tel: +902124441428 


\begin{abstract}
Başkan'dan
Üniversite olmak sadece eğitim ögretim faaliyetlerini sürdürmek anlamına gelmez. Üniversite, bu faaliyetlerin yanında sosyal ve akademik faaliyetleri de sağllklı ve kaliteli yürütülmesinden sorumludur. Üniversitemizde görev yapan her öğretim elemanının ürettiği en küçük çıktıyı değerlendirmesi ve paylaşması temel amaçlarımızdandır. Bu amaçtan hareketle yürütülen yayın faaliyetleri ise akademik anlamda en öncelikli çabamızdır. Deneyimlerin genç kuşaklara aktarılması için temel mecra olarak gördügümü̈ akademik dergi yayıncılı̆̆ında, İstanbul Aydın Üniversitesi'nin de katkısının olması amacıyla, bünyemizdeki tüm bilim, teknoloji ve sanat disiplinlerinde akademik dergi yayınlama kararı alınmıştır.
\end{abstract}

Üniversitemiz tarafindan yayınlanan İstanbul Aydın Üniversitesi Dergisi temelde teknoloji, iletişim ve sosyal bilimler arasında ilişkiler kurulması ve bu alanlar üzerine bilimsel çalışmaların yayınlanması görevini üstlenmektedir. İstanbul Aydın Üniversitesi Dergisi Sosyal Bilimler, İletişim Çalışmaları, Yeni Medya, Halkla İlişkiler, Reklamcılık alanında yapılmış olan gerek uygulamal gerekse bilimsel araştırma merkezli makaleleri yayımlamaktadır. İstanbul Aydın Üniversitesi dergisi umuyorum ki hem Türk hem de uluslararası araştırmacıların bilimsel eserler üretmesi ve bilimsel alanda ülkemizin yazın gelişimine katkıda bulunacaktır. Derginin editörü, hakemleri ve yazarlarına katkıları için teşekkürlerimi sunuyorum.

\title{
Doç. Dr. Mustafa AYDIN Mütevelli Heyet Başkanı
}

\section{Rektör'den}

İstanbul Aydın Üniversitesi içindeki tüm fakültelerimiz önemlidir ve gereklidir. Ama üniversitemizin teknoloji, iletişim ve sosyal bilimler alanında çalışmaların yapılması adına pek çok ögrenciyi yetiştiren İletişim Fakültemiz yeni medya, halkla ilişkiler, reklam gibi alanlarda araştırma yapılması adına önemli yazınla üretmektedir. Kurumların ulusal ve uluslararası ölçekte tanıtılması için yayınların yararı kuşkusuz tartışılmazdır. Akademik dergi yayıncılı̆̆ında varlı̆̆ını ortaya koyan "İstanbul Aydın Üniversitesi Dergisi", alanında önemli ve ciddi bir adımdır. Illetişim Fakültesi dekanı Prof. Hülya Yengin'e şahsında, derginin yayına hazırlanmasında emeği geçen herkesi kutluyor, başarılı bir yayın hayatı diliyorum.

\section{Prof. Dr. Yadigâr İZMiRLi $\dot{I} A \ddot{U}$ Rektörü}

\section{Editör'den}

İstanbul Aydın Üniversitesi İletişim Fakültesi tarafindan hazırlanan bilim ve sosyal bilimlere dair araştırmaları içeren 'İ́stanbul Aydın Üniversitesi Dergisi' bilimsel alana pek çok katkıda bulunan makaleleri yayınlamaktadır. Dergimize yapılan birçok araştırmacının başvurusundan, dikkatli incelemeler yapılarak yayınlanması seçilen eserler gerek ulusal gerekse uluslararası alanda önemli katkılar sağlayacaktır. İstanbul Aydın Dergisi; EBSCO, DOAJ ve Dergipark içerisinde yer alan yapısı ile gelecek sayılarında da önde gelen araştırmalara ev sahipliği yapacaktır. 



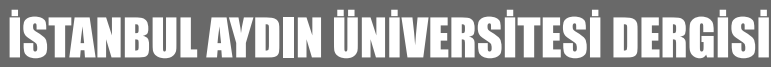

IAÜ Adına İmtiyaz Sahibi:

Doç. Dr. Mustafa AYDIN

(Mütevelli Heyet Başkanı)

Yazı İşleri Müdürü / Baş Editör:

Doç. Dr. Deniz YENGiN

Editörler Kurulu:

Arş. Gör. Tamer BAYRAK

Arş. Gör. İrem YENICELER

http://iaud.aydin.edu.tr
Teknik Hazırlık:

Akademik Çalışmalar Koordinasyon Ofisi

İdari Koordinatör

Gamze AYDIN

Türkçe Redaksiyon

Şahin BÜYÜKER

İngilizce Redaksiyon

Çiğdem TAŞ

Grafik Tasarım

Elif HAMAMCI

\section{Yazışma Adresi:}

Florya Yerleşkesi, Beşyol Mah. İnönü Cad. No:38 Küçükçekmece, İstanbul

Tel: 4441428 - Faks: 02124255759

\section{Baskı}

Armoninuans Matbaa

Adres: Tavukçuyolu Cd. Palas Sk. No:3

Y.Dudullu Ümraniye - İstanbul

Tel: 02165403611

Faks: 02165404272

E-Mail: grafik2@armoninuans.com

\section{Yayın Kurulu}

$\begin{array}{ll}\text { Prof. Dr. Hasan SAYGIN } & \text { (İstanbul Aydın Üniversitesi) } \\ \text { Prof. Dr. Cem Sefa SÜTçü } & \text { (Marmara Üniversitesi) } \\ \text { Prof. Dr. Atilla Girgin } & \text { (İstanbul Aydın Üniversitesi) } \\ \text { Prof. Dr. Güven Necati BüYüKBAYKAL } & \text { (İstanbul Üniversitesi) } \\ \text { Prof. Dr. Hamide ERTEPINAR } & \text { (İstanbul Aydın Üniversitesi) } \\ \text { Doç. Dr. And ALGÜL } & \text { (İstanbul Aydın Üniversitesi) } \\ \text { Doç. Dr. Deniz YENGiN } & \text { (İstanbul Aydın Üniversitesi) } \\ \text { Doç. Dr. Okan ORMANLI } & \text { (İstanbul Kültür Üniversitesi) }\end{array}$

\section{Bilimsel Hakem Kurulu}

Prof. Dr. Adem KaRAHOCA

Prof. Dr. Ahmet KALA

Prof. Dr. Akın MARŞAP

Prof. Dr. Ali GÜNGÖR

Prof. Dr. Aslı YAPAR GÖNENÇ

Prof. Dr. Atilla GiRGiN

Prof. Dr. Ayten KUNTMAN

Prof. Dr. Candan VARLIK

Prof. Dr. Celal Nazım İREM

Prof. Dr. Cem S. süTçï

Prof. Dr. Demir ÖNER

Prof. Dr. Emin ANARIM

Prof. Dr. Erdem BíLGiLi

Prof. Dr. Ertuğrul KARACUHA
Bahçeşehir Üniversitesi, Türkiye

İstanbul Üniversitesi, Türkiye

İstanbul Aydın Üniversitesi, Türkiye

Bahçeşehir Üniversitesi, Türkiye

İstanbul Üniversitesi, Türkiye

İstanbul Aydın Üniversitesi, Türkiye

İstanbul Üniversitesi, Türkiye

İstanbul Aydın Üniversitesi, Türkiye

İstanbul Aydın Üniversitesi, Türkiye

Marmara Üniversitesi, Türkiye

Maltepe Üniversitesi, Türkiye

Boğaziçi Üniversitesi, Türkiye

Piri Reis Üniversitesi, Türkiye

İstanbul Teknik Üniversitesi, Türkiye

İstanbul Aydın Üniversitesi Dergisi, özgün bilimsel araş̧ırmalar ile uygulama çalışmalarına yer veren ve bu niteliği ile hem araştırmacılara hem de uygulamadaki akademisyenlere seslenmeyi amaçlayan hakem sistemini kullanan bir dergidir. EBSCO ve DOAJ Tarafindan Uluslararası Taranmaktadır. 


\begin{tabular}{|c|c|}
\hline Prof. Dr. Funda DÖKMEN & Kocaeli Üniversitesi, Türkiye \\
\hline Prof. Dr. Gülümser ÜNKAYA & İstanbul Aydın Üniversitesi, Türkiye \\
\hline Prof. Dr. Güven Necati BÜYÜKBAYKAL & İstanbul Üniversitesi, Türkiye \\
\hline Prof. Dr. Halit PASTACI & Haliç Üniversitesi, Türkiye \\
\hline Prof. Dr. Hamide ERTEPINAR & İstanbul Aydın Üniversitesi,Türkiye \\
\hline Prof. Dr. Hasan Alpay HEPERKAN & İstanbul Aydın Üniversitesi, Türkiye \\
\hline Prof. Dr. Haydar ÖZPINAR & İstanbul Ayvansaray Üniversitesi, Türkiye \\
\hline Prof. Dr. Hülya YENǦiN & İstanbul Aydın Üniversitesi, Türkiye \\
\hline Prof. Dr. Hüseyin Erol AKATA & İstanbul Aydın Üniversitesi,Türkiye \\
\hline Prof. Dr. Korkmaz ALEMDAR & Atılım Üniversitesi, Türkiye \\
\hline Prof. Dr. M. Nafiz DURU & İstanbul Aydın Üniversitesi, Türkiye \\
\hline Prof. Dr. M. Nazmi ERCAN & İstanbul Aydın Üniversitesi, Türkiye \\
\hline Prof. Dr. Mehmet Fatih ALTAN & İstanbul Aydın Üniversitesi, Türkiye \\
\hline Prof. Dr. Mehmet Güneş GENÇYILMAZ & İstanbul Aydın Üniversitesi, Türkiye \\
\hline Prof. Dr. Melda Cinman ŞiMŞEK & Marmara Üniversitesi, Türkiye \\
\hline Prof. Dr. Mesut KARTAL & İstanbul Teknik Üniversitesi,Türkiye \\
\hline Prof. Dr. Murat CEYLAN & Selçuk Üniversitesi, Türkiye \\
\hline Prof. Dr. Nazife GÜNGÖR & Üsküdar Üniversitesi, Türkiye \\
\hline Prof. Dr. Nizamettin AYDIN & Yıldız Teknik Üniversitesi, Türkiye \\
\hline Prof. Dr. Nüket SivRi & İstanbul Üniversitesi, Türkiye \\
\hline Prof. Dr. Nurhan BABÜR TOSUN & Marmara Üniversitesi, Türkiye \\
\hline Prof. Dr. Özden CANKAYA & İstanbul Aydın Üniversitesi, Türkiye \\
\hline Prof. Dr. Özer KANBUROǦLU & İstanbul Aydın Üniversitesi, Türkiye \\
\hline Prof. Dr. Şeref SOYLU & Sakarya Üniversitesi, Türkiye \\
\hline Prof. Dr. Suat GEZGiN & İstanbul Üniversitesi, Türkiye \\
\hline Prof. Dr. Şuayip KARAKAŞ & İstanbul Aydın Üniversitesi, Türkiye \\
\hline Prof. Dr. Turhan Nejat ARAL & İstanbul Aydın Üniversitesi, Türkiye \\
\hline Prof. Dr. Vahit DOǦAN & Gazi Üniversitesi, Türkiye \\
\hline Prof. Dr. Veysel GÜNAY & İstanbul Aydın Üniversitesi, Türkiye \\
\hline Prof. Dr. Yalçın ÇEKiç & Bahçeşehir Üniversitesi, Türkiye \\
\hline Doç. Dr. And ALGÜL & İstanbul Aydın Üniversitesi, Türkiye \\
\hline Doç. Dr. Ceyda ILGAZ BÜYÜKBAYKAL & İstanbul Üniversitesi, Türkiye \\
\hline Doç. Dr. Deniz YENGiN & İstanbul Aydın Üniversitesi, Türkiye \\
\hline Doç. Dr. Okan ORMANLI & İstanbul Kültür Üniversitesi, Türkiye \\
\hline Doç. Dr. Tolga KARA & Marmara Üniversitesi, Türkiye \\
\hline Dr. Öğr. Üyesi Cihan BECAN & Üsküdar Üniversitesi, Türkiye \\
\hline Dr. Öğr. Üyesi Ercan ÖGE & İstanbul Aydın Üniversitesi, Türkiye \\
\hline \multicolumn{2}{|c|}{ Dr. Öğr. Üyesi Gökmen Hakan KARADAĞ İstanbul Aydın Üniversitesi, Türkiye } \\
\hline
\end{tabular}




\section{Editörden}

Sevgili İstanbul Aydın Üniversitesi Dergisi Okuyucuları,

İÄD’nin, Ekim 2019 Cilt 11 Sayı 4 (44. sayı) yayınımızı sizlerle paylaşmaktan mutluluk duyuyoruz. Dergimizin yayınlanan bu sayısında titiz hakem süreci sonrasinda kabul edilen 8 yazarın 5 makalesi bulunmaktadır.

Sevgili okurlar, daha detaylı bilgi almak, öneri ve görüşleriniz paylaşmak ya da eserlerinizi yayınlatmak için gönderimlerinizi lütfen aşağıdaki e-posta adresine iletin. Bizlere İÄ̈D Sekreterliği iaud@aydin.edu.tr adresinden ulaşabilirsiniz.

Illetişimde kalmak ve bir sonraki sayımızda buluşmak umudu ile.

Sayglarımla,

\section{Editör}

Doç. Dr. Deniz YENGIN

İstanbul Aydın Üniversitesi

Florya Kampüsü 34295

Istanbul TÜRKIYE

Tel: +902124441428

E-mail:denizyengin@aydin.edu.tr

URL: http://iaud.aydin.edu.tr 


\section{ISTANBUL AYDIN ÜNIVERSITESI}

Cilt: 11 Sayı: 4 Ekim 2019

\section{DERGISI}

\section{Içindekiler}

Content

Doç. Dr. Deniz YENGiN, Editörden

\section{ARAŞTIRMA MAKALELERI \\ (RESEARCH ARTICLES)}

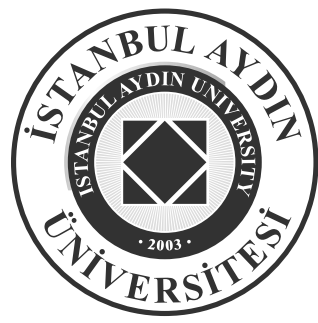

KÜLTÜR ENDÜSTRISININ GÜNDEM BELIRLEME VE KAMUOYU OLUŞTURMA IŞLEVi

AGENDA SETTING AND PUBLIC OPINION CREATION FUNCTION OF THE CULTURAL INDUSTRY

Ayten ÖVÜR .319

A STUDY ON THE RELATION BETWEEN CONSOLIDATION COEFFICIENT AND PLASTICITY INDEX OF FINE-GRADED SOILS

INCE-DANELI ZEMINLERIN KONSOLIDASYON KATSAYISI ILE PLASTISITE INDEKSI ARASINDAKI ILISSKININ INCELENMESI Kaveh DEHGHANIAN, Emrah ÇALTILI

HASILATIN TFRS 15 MÜșTERI SÖZLEŞMELERINDEN HASILAT STANDARDI, BOBi FRS BÖLÜM 5 VE VERGi KANUNLARINA GÖRE KARŞILAŞTIRMALI INCELENMESI

A COMPARATIVE REVENUE ANALYSIS ACCORDING TO THE REVENUE STANDARDS OF IFRS 15 CUSTOMER CONTRACTS, BOBI FRS 5 AND TAX LAWS

Yıldırrm Ercan ÇALLŞ, Burcu HIŞMAN .355

YÜKSEKÖĞRETIMDE SOSYAL SORUMLULUK PROJELERI; ÖĞRETMEN GÖRÜŞLERI ÜZERINE BIR ARAŞTIRMA SOCIAL RESPONSIBILITY PROJECTS IN HIGHER EDUCATION: A REASEARCH ON THEACHERS VIEWS Hicran Özlem ILGIN .379

TEKNOLOJi VE SIBER GÜVENLIK: DIJITAL TOPLUMUN GELECEĞi TECHNOLOGY AND CYBER SECURITY THE FUTURE OF DIGITAL SOCIETY Irfan ATASOY, Okan ORMANLI. . .399 


\title{
ISTANBUL AYDIN ÜNIVERSITESI
}

Cilt: 11 Sayl: 4 Ekim 2019

DERGisi

DOI LISTELERI

KÜLTÜR ENDÜSTRISININ GÜNDEM BELIRLEME VE KAMUOYU OLUŞTURMA IŞLEVi

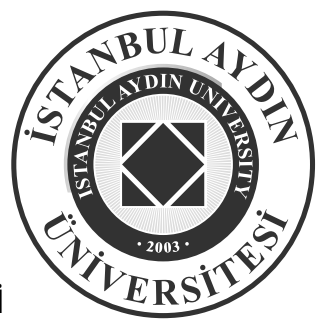

Ayten ÖVÜR

Link: http://iaud.aydin.edu.tr/wp-content/uploads/2019/09/iaud_v11i4001.pdf

DOI N0: 10.17932/IAU.IAUD.m.13091352.2019.4/44.319-343

\section{A STUDY ON THE RELATION BETWEEN CONSOLIDATION COEFFICIENT AND PLASTICITY INDEX OF FINE-GRADED SOILS \\ Kaveh DEHGHANIAN, Emrah ÇALTILI \\ Link: http://iaud.aydin.edu.tr/wp-content/uploads/2019/09/iaud_v11i4002.pdf \\ DOI N0: 10.17932/IAU.IAUD.m.13091352.2019.4/44.345-354}

\author{
HASILATIN TFRS 15 MÜŞTERI SÖZLEŞMELERINDEN HASILAT STANDARDI, BOBi FRS BÖLÜM 5 VE VERGI \\ KANUNLARINA GÖRE KARŞILAŞTIRMALI INCELENMESI \\ Yıldırım Ercan ÇALIŞ, Burcu HIŞMAN \\ Link: http://iaud.aydin.edu.tr/wp-content/uploads/2019/09/iaud_v11i4003.pdf \\ DOI N0: 10.17932/IAU.IAUD.m.13091352.2019.4/44.355-377
}

YÜKSEKÖĞRETIMDE SOSYAL SORUMLULUK PROJELERI; ÖĞRETMEN GÖRÜŞLERi ÜZERINE BIR ARAŞTIRMA

Hicran Özlem ILGIN

Link: http://iaud.aydin.edu.tr/wp-content/uploads/2019/09/iaud_v11i4004.pdf

DOI N0: 10.17932/IAU.IAUD.m.13091352.2019.4/44.379-398

\section{TEKNOLOJI VE SIBER GÜVENLIK: DIJITAL TOPLUMUN GELECEĞi}

İran ATASOY, Okan ORMANLI

Link: http://iaud.aydin.edu.tr/wp-content/uploads/2019/09/iaud_v11i4005.pdf

DOI N0: 10.17932/IAU.IAUD.m.13091352.2019.4/44.399-409 



\title{
KÜLTÜR ENDÜSTRIISININ GÜNDEM BELIRLEME VE KAMUOYU OLUŞTURMA İŞLEVI
}

\author{
Dr. Öğretim Üyesi Ayten ÖVÜR \\ İstanbul Aydın Üniversitesi, İstanbul \\ aytenovur@gmail.com \\ https://orcid.org/0000-0003-2497-9703
}

\section{ÖZ}

Gündem belirleme, medya aracılığıyla toplumun bazı güncel sorunların görece öneminialgılamasınıntemeliniaçıklamayaçalışanbiriletişimkuramıdır. Geleneksel gündem belirleme yaklaşımına göre, insanlar ne hakkında düşüneceklerini ve konuşacaklarını medya aracılığıyla gelen mesajlardan öğrenmekte ve böylece oluşan gündemler siyasal gündemi şu ya da bu şekilde etkilemektedir. Türkiye'ye baktığımızda medyanın, siyasetin gündemini belirleme gücünün eskiye göre biraz daha azalmış olduğu görülmektedir. Daha çok siyasal gündemin ve siyasilerin, medyanın ve kamunun gündemini belirlediği izlenmektedir. Siyasal gündemin, medya ve kamu gündemini yönlendirmesinde etkili olan faktörlerin başında ise kültür endüstrisini ve yaratımlarını iyi kavramış bilinçli ve güçlü yöneticilerin olduğunu söylemek mümkündür. Eleştirel bir yaklaşımla hazırlanan bu çalışmada amaç gündemi kimlerin, neye göre belirlediğiyle ilgili çıkarımlarda bulunmak; Türkiye'deki değişen uygulamalarına ilişkin genel bir bakış açısı sağlamaktır.

Anahtar Kelimeler: Gündem Belirleme, Medya, Катиоуи. 


\title{
AGENDA SETTING AND PUBLIC OPINION CREATION FUNCTION OF THE CULTURAL INDUSTRY
}

\begin{abstract}
Agenda setting is a communication theory that attempts to explain the basis of the society's perception of the relative importance of some current issues through the media. According to the agenda-setting approach, people learn what to think and talk about from the messages that they receive through the media, and the resulting agendas affect the political agenda in one way or another. When we look at Turkey, it is seen that Media's power to determine the agenda of politics has slightly decreased. It is observed that mostly political agenda and politics determine the agenda of the media and the public. It is possible to say that the main factors that political agenda influences media and public agenda is the powerful politicians who are well-versed about cultural industry and its gains. The purpose of this study, which is prepared with a critical approach, is to find out who are setting the agenda and according to what as well as providing an overview of the changing practices in Turkey.
\end{abstract}

Keywords: Agenda-Setting, Media, Public Opinion.

\section{GİRIŞ}

Türkiye'de medyayı az çok takip eden ya da medyanın içinde olanların sık sık dikkat çektiği bir konu vardır. $O$ da, Türkiye'de gündemin çok hızlı değiştiği ve takip etmenin çok zor olduğu gerçeğidir. 2-3 gün hasta olup da ya da yurt dışında olup da medyayı takip etmezseniz, geri döndüğünüzde görürsünüz ki gündemi tamamen kaçırmışsınızdır ve olup bitenlerin çok gerisinde kalmışsınızdır.

İyi, ama gündemin bu kadar hızlı değişmesini sağlayan sebepler ya da faktörler nelerdir? Neden dünyanın diğer ülkelerinde, özellikle bazı Avrupa ülkeleri ve Amerika'da, gündem bu kadar hızlı değişmez ve ya bu kadar olay olmaz? Ya da olsa bile bizdeki kadar medyanın gündemini kaplamaz ve dolayısıyla kamunun gündemini de meşgul etmez. Bu sorular uzun yıllardır benim gibi dış haberlerde çalışan editörler ve muhabirler arasında sıklıkla tartışılan konulardan olmuştur. $\mathrm{Bu}$ tartışmalar sonucunda üzerinde bir uzlaşma sağlanamasa da farklı etmenlerin ön plana çıktığı görülür. Bunların nedenini Ortadoğu gibi oldukça çalkantılı bir coğrafyaya yakın bulunmak, büyük devletlerin arka bahçesi olmak, zor ve güç durumlarda siyasilerin hedef değiştirme çalışmaları olarak görmek, onların amaçları doğrultusunda yayın yapmak ya da kamu olarak siyasetle fazla içli dışlı olmak gibi farklı etmenlere bağlamak olasıdır. 
Gündem belirlemenin ve amaç hasıl olana kadar konuyu gündemde tutmanın kamuoyunda yaratacağ etkiler göz önünde bulundurulduğunda, kitleleri harekete geçirmek ve siyasete şekil vermek isteyenler için gündem belirleme çalışmalarının ne kadar büyük önem arz ettiği aşikardır. Gündem belirleme çalışmaları ve rekabeti dünyanın her yerinde siyasi, ticari veya kültürel amaçlarına ulaşmak isteyenler için bir ilgi konusu olmaya devam etmektedir.

\section{KİTLE KÜLTÜRÜ VE KİTLE TOPLUMU}

Kitle kültürü, belirli bir endüstrileşme tekniğine dayanan, endüstrileşme ile beraber ortaya çıkmış ve geniş halk kitlelerine yayılan davranışlar ve gösteriler bütünüdür (Gönenç, 2002: 129). Kitle kültürü, "Her şeyi birbirine kaynaştırır, karıştırır ve homojenleşmiş bir kültür yaratır. Kitle kültürü, hiçbir şey arasında ya da hiçbir şeye karşı ayrımcılık yapmaz.” Sonuçta kültür karşı konulmaz bir şekilde törpülenir ve standartlar kaybolur: kapitalist kültür ve yapıtları metaya dönüşür. İşlevi, eğlendirmek, saptırmak ve bilinci topyekûn edilgenlik noktasına indirmek olur (Swingewood, 1996: 16).

Ünsal Oskay'a göre, kitle kültürü ürünleri, kişinin reel toplumsal yaşamını "haklılaştırıcı" ve kaçışçı fantazyayı yaşamın zorunlu öğesine dönüştürücü bir işlev üstlenir. Batı toplumlarındaki yönetim felsefesi geleneğindeki "aydınlanmış yurttaş"a erişme amacı da değişerek, kısa sürede tutum ve davranışları belirli bir yönde değiştirilmek istenen ve "müş̧eri" durumuna indirgenmiş kitle toplumu insanına seslenme biçimine dönüşür (Akt. Türkoğlu, 2004: 141). Kitle kültürü ve kitle toplumu birbiriyle ilintili kavramlardır. Adorno ve Horkheimer'ın deyişiyle kitle toplumu, "Öne çıkan her şeyi eşit kılan ve kalburüstülüğün bütünleyicisi olan toplumsal mekanizma yıldız kültürünün bir parçasıdır. Yıldızlar, dünyayı saran hazır giyime ve sarkan iplikleri kesip atan hukuki ve ekonomik adaletin makasına uygun kalıplardır, o kadar." (Adorno ve Horkheimer, 2010: 314).

C. Wright Mills'e göre ise kitle toplumunda, modern toplumdaki yapısal eğilim ve onun iletişimsel tekniğinin yönlendirici niteliği, birbirine denk düşme noktasına varmıştır. Erkek ve kadınları dar, rutin çevrelere hapsetmiştir. Metropoliten toplumdaki kitleler artık birbirlerini yalnızca ihtisaslaşmış ortamlar içindeki parçalar olarak tanımlamaktadırlar: arabayı tamir eden adam, yemeği önümüze getiren kız, satış elemanı, gün boyunca okulda çocuğumuza göz kulak olan kadın... Rutinlerine gömülmüş olan bu kişiler az ya da çok daraltılmış yaşamlarını aşamamakta, toplumların yapısı ve bunun içinde birer kamu olarak rolleri hakkında bir fikir edinememektedirler (Akt. Swingewood, 1996: 30). 
Frankfurt Okulu'nun kitle toplumu kuramında da iki tema hâkimdir:

- Yoğun ekonomik ve teknolojik gelişme karşısında geleneksel toplumsallaşma kurumlarının zayıflaması;

- İnsanın emek ve etkinliği sonucu ortaya çıkan nesnelerin insan kontrolünün dışında gözüken bağımsız, özerk güçlere dönüştüğü kültürün artan somutlaşması.

Böylece kitle toplumunun parçalanmış insanı 'anlaşılmaz bir zorunluluk' tarafindan yönetilmektedir. Horkheimer, modern toplumun "rasyonelleşmiş, otomatik, tümüyle yönlendirilen" bir dünyaya doğru giderken, bireylerin özerkliklerinin tüm izlerini yok ettiğini söylemektedir (Swingewood, 1996: 32). Bir yandan insanların aynı seviyeye getirilmesine, özerkliklerini yitirmesine ve standartlaştırılmasına, öte yandan da önder şahsiyet olarak adlandırılanlara, sahip oldukları erke karşılık gelecek biçimde yetkinleşmiş bir bireyselliğin eşlik ettiği kanısı bir yanılgı ve bizzat ideolojinin bir parçasıdır (Adorno ve Horkheimer, 2010: 314).

Oskay ise kitle toplumu yaşamının özelliklerini şöyle sıralar:

- İnsan ile insan arasındaki ilişkileri meta ile meta arası ilişkiler olarak göstermesi, böylece insana ilişkin birçok sorunun karşısında duygusuz ve sorumsuz kalabilmesi;

- Sistemin kendi işleyiş̧ mantığına göre işlemesindeki "etkinlik" sorununu, insanın daha özgür yaşama ulaşabilme sorununun üstünde tutması;

- Bilgiyi ve teknolojiyi, bu etkinlik anlayışının sınırlamaları içinde işlevlendirip edilginleştirmesi, evcilleştirmesi, hatta yaşama karşıt tutucu bir güç haline dönüştürmesi;

- Bu olup bitenlerin mistifiye edilmesi için kitlenin önüne özgürleşme yerine, ikame edilmiş sınırsız bir tüketim olanăg çıkarması, ama bunun akıldışı bir tüketimi, yani insanı insana tükettiren, insanın daha üst değerlere ulaşmasını engelleyip onu çocuklaştıran bir tüketim oluşu;

- Sanat ve kültür yaşamında, hayatın gerçekten özgür ve bilinçli özneler olarak yaşanabilme olanağının yitirilmesinden kaynaklanan şiddete, ileri yaş çocuklaşmasına, av/avcı ilişkisine indirgenmiş bir cinselliğe, gerçeklikten uzaklaşmaya yarayan bir kaçışa yönelmiş kitle kültürü eğlencelerine, eğlenimlerine ve bilinçsizleştirmelerine geçilmiş oluşudur (Oskay, 2013: 33).

John Fiske'ye göre, kapitalizmin kültür endüstrisi tarafindan üretilen kültürel ürünler anlamına gelen kitle kültürüyle, halkın bu ürünleri kullanarak kendi anlamlarını yaratmalarını ifade eden popüler kültür arasında önemli bir farklılık vardır (Fiske, 2012: 36). Kitle kültürü; işbölümü altında, bant üretim sistemi 
içinde, endüstriyel olarak üretilen ürünler için kullanılan bir terimdir. Popüler kültürse herkes tarafından sevilen ve kullanılan ürünleri anlatır (Türkoğlu, 2004: 92). Fiske, Popüler Kültürü Anlamak adlı kitabında kitle kültürünün tahakküm kurma ve türdeşleştirme girişimleri üzerine odaklanmak yerine, popüler kültürün bu girişimleri boşa çıkarma yolları üzerinde durmuştur. (Fiske, 2012: 36)'ye göre, "Popüler kültürü üreten halktır, kültür endüstrisi değil. Kültür endüstrilerinin elinden gelen tek şey, çeşitli halk oluşumlarının kendi popüler kültürlerini yaratma sürecinde kullanabilecekleri ya da reddedebilecekleri bir metinler ya da kültürel kaynaklar dağarcığı üretmektir.” Ancak konumu sağlamlaştıkça, kültür endüstrisi tüketici gereksinimleriyle istediğini yapar hale gelebilir; bu gereksinimleri üretebilir, yönlendirebilir, denetim altına alabilir, hatta eğlenceye son verebilir: burada kültürel ilerlemeye sınır koyulmamıştır (Adorno, 2012: 78).

Adorno'ya göre de kültür endüstrisi ve iktidar arasında kimi bağlar vardır. Gelişen teknoloji, yaşam koşulları ve iktidar ilişkileri birbirlerine paralel olarak değişir. Adorno, kültürden söz edenin bilerek ya da bilmeyerek yönetimden söz ettiğini söyler. Artık kültür bir meta olmuştur. Çünkü kültür planlanıp yönetildiğinde zarar görür. Kültür endüstrisinde iktidarın silahları artık kılıç, bomba ve makineli tüfek değil; kültür, moda, reklam, sinema, televizyon ve radyo olmuştur (Akt. Sönmeyen, 2012: 2).

Birçoklarına göre de, kültür endüstrisinin ürettiği en önemli ürün reklamc1lara satılan metalaştırılmış izlerkitledir. Yapım stüdyoları bir meta, bir program üretirler ve bunu kâr amacıyla dağıtımcılara, yayıncılara, kablolu yayın kurumlarına satarlar. Bu bütün metalar içinde geçerli basit bir mali mübadeledir. Ama iş bu kadarla bitmez, çünkü televizyon programı ya da kültürel meta, maddi bir meta olarak mini firınla ya da kot pantolonla aynı türden bir meta değildir. Bir televizyon programının ekonomik işlevi satıldığı anda sona ermez, çünkü program tüketim anında değişerek bir üretici haline gelir, ürettiği şeyse reklamcılara satılan izlerkitledir (Fiske, 2012: 39).

Kültür endüstrisi sayesinde yeni alanlara yayllan medya gösterisi ise, aslında baskın rol modeller, moda, görüntü ve kişilik sembolleri sunan bir şöhret kültürüdür. Medya gösterileri; ekonomiden kültüre, günlük yaşantıdan politika ve savaşa kadar hayatın her alanını istila etmektedir. Dahası gösteri kültürü, gelecekte multimedya gösterilerin ve bir network gibi birbirine bağlı eğitlence toplumlarının oluşmasına yardım edecek olan sanal gerçekliğin yeni alanlarına doğru taşınmaktadır (Kellner, 2010: 37). Medya gösterileri ile gündemi değiştirmek ise gün geçtikçe kolay hale gelmiştir. Teknolojinin de yardımıyla çok daha inandırıcı medya gösterileri hazırlanmış, bu sayede de kamuoyu ve kamu gündemi yönetilmiştir. 


\section{KAMUOYU KAVRAMI}

İletişim Sözlüğü'nde kamuoyu, "Halkın kamusal ilgi konularına ilişkin kanılarının toplamı; genel kamunun üyelerinin siyasi konular ya da güncel olaylar hakkındaki tutumlarının anlatımları" şeklinde tanımlanmaktadır. Türk Dil Kurumu Sözlügü̈'nde ise kamuoyu, "Bir konuyla ilgili halkın genel düşüncesi, halkoyu" şeklinde açıklanmaktadır. Kamuoyu kavramı genel olarak, "Belli bir toplum içinde yaşayan insanların belli bir olgu ya da inanç üzerindeki ortak yargısı" şeklinde ifade edilmektedir (Yüksel, 2007: 572).

Kamuoyu, gündelik kullanımda genellikle çok sayıda bireylerden oluşan toplulukların kolektif kanaatlerini açıklamak için kullanılır. Bu anlamıyla kavram kitle kanaati ile eşanlamlıdır. Sözlük anlamı açısından "kamu" kelimesi umumi, herkese ait, halk kelimelerinin her üçünü de kapsamaktadır. Bu nedenle kamuoyundaki "kamu" ifadesini her üç anlamı da ifade eden bir teknik terim olarak anlamak gerekir. Başka bir deyişle "kamu" kolektif bir deyimdir. Aynı zamanda kamu terimi bu anlamları ile birlikte belirli vasıfları haiz bir toplumsal gruba atıfta bulunmaktadır. Özellikle 1950'lerden itibaren yapılan araştırmalar, sosyal bilimcilerin üzerinde birleştikleri noktanın, "kamu" teriminin "grup" ile eşanlamlı kullanımı olduğunu göstermiştir. Kamuoyu kavramının ikinci unsuru "oy" kelimesi ise tartışmalı bir konuda ifade edilen kanaat, düşünce anlamındadır (Bektaş, 2013: 41-49). Hennessy'e göre, kamuoyu kavramına dair çok sayıda tanımlama vardır, ama terimi anlamak için onu modern bilimde ilk kullanan kişi olan Machiavelli'ye gitmek gerekir. Machiavelle, "Akıllı bir adamın, ofislerdeki terfi ve görev dağglımı gibi belirli durumlarda bile kamuoyunu göz ardı etmeyeceğini" vurgular ve bu şekilde çoğunluğun görüşlerine saygıya ve öneme dikkat çeker (Akt. Yeğen, 2014: 24).

Tanımı gereğince, çoğunluğun kanaatlerini yansıtan kamuoyu, yöneticilerin siyasal karar alma sürecini etkileme gücüne sahip olması ve seçenlerle yönetenler arasında iki yönlü ilişki kurulmasını temin etmesi gibi nedenlerle, siyaset biliminin temel ilgi alanlarından birisi olmuştur. Kamuoyu oluşumu ile ilgili çalışmalar özellikle ABD'de yaygınlık kazanmıştır. Araştırmacılar, kamuoyu oluşumu sürecinde sosyolojik ve psikolojik etkenleri birbirinden ayırmışlar ve kanaatlerin biçimlenmesinde bu etkenlerin farklı roller oynadıklarını belirtmişlerdir. Kamuoyu ile ilgili olarak uzun süre hâkim olan görüş şuydu: "Belli bir sorunla karşılaşan insanlar, bu sorunla ilgili verileri tartarak bilinçli, rasyonel (akılcı) sonuçlara varırlar; böylece ulaşılan kanaatlerde kamuoyunu meydana getirir." Ancak daha sonra yapılan çalışmalar, bu kuramın dayandığg varsayımın geçerli sayılamayacağını, çünkü. "Kamuoyunun kaynağında çoğu zaman bu nitelikte rasyonel, bilinçli bir değerlendirmenin bulunmadığını ve somut sorunlar karşısında beliren fikir ve tutumları genellikle önceden biçimlenmiş kanaatlerin 
tayin ettiği”" ortaya konmuştur. Bireyin kanaati bir kişisel davranış türüdür. Gösterilen her davranış kişinin istek ve gereksinimlerinin bir tepkisi sayılabilir. Bununla birlikte bireyin istek ve gereksinimleri ancak iç dünyası ile dış dünyası arasındaki ilişkiler çerçevesinde şekillenmektedir. Başka bir ifadeyle bireyin kanaatleri kişisel yapısı ile içinde bulunduğu çevrenin karşılıklı etkileşimleri sonucunda oluşmaktadır (Bektaş, 2013: 71-72).

Kamuoyunun oluşmasında etkili olan psikolojik faktörler, tutumlar ve kanaatlerdir. Kamuoyu oluşurken önce tutumlar, buna paralel olarak da kanaatler oluşmaktadır. Bireyin kanaatlerinin oluşmasındaysa, bireyin içinde bulunduğu çevre ve bu çevreyi meydana getiren kurumlar etkilidir. Kanaatlerin biçimlenmesinde rol oynayan ortamdan gelen unsurlar arasında öncelik tanınanı birincil ve ikincil gruplardır. Kamuoyunun oluşmasında etkili olan kurumlardan birincil gruplar, öğrenme sürecinin hızlı bir faaliyet gösterdiği birey yaşantısının ilk yıllarında bireyin tavırlarını, görüşlerini, inançlarını ve kanaatlerini etkileyen ve oluşturan aile ve okul gibi gruplardır. Üyeleri arasındaki ilişkinin kişisel ve yakın olmadığı gruplar ise ikincil gruplardır. Birincil gruplar yüz yüze ilişkiyi kurduğu, doğrudan doğruya karşıdaki insanla teması sağladığı için önemlidir; ikincil gruplar ise "referans grupları" görevini gördükleri, yani kişinin bir grupla özdeşleşmesini sağladıkları için önemlidir. Referans grupları ve bu gruplarla özdeşleşme insanların en derin inançlarını ve duygularını etkiler; yaşantısı boyunca bir yandan kendisini kabul etmesini istediği insanları, öte yandan sosyal özdeşleşmesini, yani toplum içindeki yerini belirler (Ertaş, 2000: 28-33).

Kitle psikolojisi açısından baktığımızda da, toplumsallık duygusu, kitle dışındaki bir kişiye karşı ortak bir sevgi bağlanımıyla gerçekleşmektedir. Kitlelerin varlığı da, tüm kitle bireylerinin bir kişi, yani önder tarafından aynı şekilde sevilme koşuluna dayanmaktadır. Dolayısıyla liderlerin tüm kitleyi ayrım yapmadan, tarafsız bir şekilde yönetmesi; herkese aynı mesafede olması ve onları koruması kitle içindeki huzur ve birlik duygusu için önemli bir unsurdur. Kitledeki bir özellik, kitle bireyleri arasında eşitliğin hiç şaşmaksızın istendiği gerçeğidir. Ancak şurasını da belirtmek gerekir ki, kitledeki eşitlik isteği yalnız bireyler bakımındandır, önderin kendisi bunun dışında bulunur. Bütün bireyler birbirine eşit olmayı, ama hepsi de bir önder tarafından yönetilmeyi isterler. Birbirleriyle özdeşleşebilen, birbirleriyle eşit haklara sahip pek çok birey ve bütün bireylerin üstünde bir kişi; Freud'a göre işte yaşam gücünü içeren bir kitlede görülen durum budur (Freud, 2015: 76). Bunun için toplumlarda ideolojiler/partiler üstü her kesimi kapsayan bir liderin olması huzur ve birlik duygusu için önemlidir. İngiltere'deki kraliyet ailesinin ya da parlamenter sistemdeki her partiye eşit mesafedeki cumhurbaşkanının bu etkiyi sağladığı söylenebilir. 
Yapılan çalışmalar, kitlenin genel psikolojisinin, istek ve arzularının dikkate alınarak kamuoyu oluşturması çalışmalarının daha etkili sonuç verdiğini göstermektedir. Araştırmacılar da uzun yıllardır kitleleri etkilemek, onların kanaat, tutum ve davranışlarını değiştirmek için neler yapılması gerektiğini tespit etmek için çeşitli gruplar üzerinde psikolojik ölçümler ve testleri de içeren çalışmalar yapmışlardır.

Kamuoyu kavramı üzerine yapılan çeşitli yorumlar, onun her zaman bilinçli ve rasyonel şekilde oluşmadığ 1 ve durumsal olarak meydana geldiği yönündedir (Eke, 2008: 74). Kamuoyunu, fikirlerin ve kanaatlerin kamu içerisinde ifade edilmesi olarak tanımlayan Wilhelm Bauer de kamuoyunu, durağan ve devinen yönleriyle ele almıştır. Örf ve adetler gibi kolay değişmeyen ve kalıplaşan kanaat ve tutumları kamuoyunun durağan yönünü, ikna ve propaganda ile değişebilen ve etki altına alınabilen kanaat ve tutumları, kamuoyunun devinen yönünü betimlemektedir. Kamuoyunun oluşumunda:

- Birinci aşama, kitle davranışı dönemidir. Kanaatler bu dönemde birincil gruplar içinde oluşmaktadır.

- İkinci aşama, kamusal tartışmalar ve çelişkiler dönemidir. Bu dönemde biçimlenen kanaatler ikincil gruplara aktarılmaktadır.

- Son aşama ise kurumsallaşmış karar verme aşamasıdır. Bu aşama sonucunda da olumlu ya da olumsuz bir eylem ortaya konulmaktadır.

Kamuoyu oluşumu sürecinde, kitle davranışı döneminden kamusal tartışmalar ve çelişkiler aşamasına geçişte, yani bireylerin ilgi duydukları, çıkar sağladıkları veya sorun olarak algıladıkları konulara ilişkin ortak bilinç ve görüş birliklerinin sağlanması aşamasında, enformasyon ve mesaj alışverişinin aynı anda gerçekleşmesi, yani sosyal etkileşim önemli bir rol oynamaktadır. Sonraki aşama olan karar verme aşamasının tamamlanarak kamuoyu oluşumunun gerçekleşmesi de sosyal etkileşimin sürdürülebilmesi ile mümkün olmaktadır. Bu sebepten dolayı denebilir ki aynı anda çok sayıda bireye ulaşarak kanaat ve tutumların gelişmesinde rol oynayan, sosyal etkileşimi mümkün kılan faktör iletişimdir (Kamanlığlu, 2007: 9). Adorno ve Horkheimer, Aydınlanmanın Diyalektiği'ne yazdıkları sunuşta, kamuoyunun artık bir meta haline geldiğini, dilin de o metanın tanıtımını yapan bir araç olduğunu yazarlar (Adorno, 2012: 17).

Kamuoyunun oluşmasında etkili olan bir diğer önemli faktör ise baskı gruplarıdır. Sosyoekonomik düzeyi ne olursa olsun, tüm ülkelerin yönetim yapısında yer alan baskı gruplarının, siyasi mekanizma içindeki önemi yadsınamaz. Baskı grupları çoğu zaman toplumun genel çıkarları anlamına da gelen kendi özel çıkarlarını, devlet yönetimini ellerinde tutanlara ileterek, kamuoyu oluşturmakta ve böylece sürekli olarak siyaset arenasında rol oynayabilmektedirler. Kanaat önderleri de 
kamuoyu oluşturmada çok etkili bir başka faktördür. Kanaat önderlerinin etkili olmalarının başlıca nedeni, kitle haberleşme araçlarını daha çok izlemeleri ve bunların gayrişahsi, soyut muhtevasını kişisel ilişkiler içerisinde çevrelerindeki kimselere iletmelerinden ileri gelmektedir. Kamuoyunun oluşmasında etkili olan bir diğer kurum da toplumun ve dolayısıyla da bireylerin sahip oldukları kültürel yapıdır. Kamuoyu, kısaca, bir konu ile ilgilenen grupların kanaat ifade etme, tartı̧̧ma ve karşl1ıklı etkileşme süreçlerinin ürünü olduğuna göre, bireylerin ve grupların kanaatlerini ifade etmelerini ve tartışmaya girişmelerini olanaklı kılan hukuki ve siyasal ortamın varlığı ise bu davranış için vazgeçilmez bir ön koşuldur. Hukuki ortamı anayasa ve diğer yasalar, siyasal ortamı da yönetimi elinde tutan siyasal organın kararları ve uygulamaları sağlar (Ertaş, 2000: 36-45).

Kamuoyunun oluşumu ve niteliğiyle onun içinde oluştuğu siyasal sistem ve ortam arasında ise yakın bir ilişki vardır. Genellikle demokratik rejimlerde serbestçe "oluşan" kamuoyu ile demokratik olmayan (otoriter ve totaliter) rejimlerde “oluşturulan” kamuoyu arasında bir ayrım yapmak gerekir (Bektaş, 2013: 9).

Kamuoyunun esas varlık sebebi, karar organlarının karar verme sürecine katılarak alınacak kararları kendi istedikleri yönde etkilemektir. Burada kanaatlerin şekillenmesinde, duyurulmasında, yayılmasında ve sonuçta kamuoyu olarak belirlenmesinde iki önemli unsur rol oynar. Bunlardan biri, bu kanaatlerin örgütlenme yeteneği diğeri ise kitle iletişim araçlarını kullanmada sahip oldukları üstünlüktür. Açılanamayan kanaatler kamuoyu olarak nitelendirilemeyeceğine göre, örgütlenme ve kitle iletişim araçlarının kullanılması, kanaatlerin kamuoyu olarak ifade edilmesinde son derece önemli unsurlardır. Sonuç olarak kamuoyu özellikle siyasi kararların alınması ve uygulanması üzerinde siyasi iktidara yaptığı baskı açısından oldukça önemli bir yere sahiptir. Günümüzde özellikle iletişim araçları sayesinde kamuoyu etkili hale gelmiş ve gündemi etkilemeye devam etmektedir. Kitle iletişim araçları haber ve bilgi değerine sahip olan içerikleriyle kamuoyunun oluşumu sürecinde önemli roller üstlenmektedir (Ertaş, 2000: 3644). Günümüzde kamuoyu oluşumunda en büyük etki sahibinin medya olduğu görülmektedir. Özellikle gençler arasında ise yeni medyanın gücünün arttığı gözlenmektedir.

\section{MEDYA VE KAMUOYU İLIŞKISİ}

Kitle iletişimin başlangıcı, kitlelerin toplumsal hayata ve siyasal etkinlilere katılma yolundaki mücadeleleriyle, beklentileriyle koşut gelişmiştir (Oskay, 2013: 31). İnsanlar, kitle iletişimine kendi yaşam ortamları hakkında bilgi sahibi olmak için girmektedirler. Beslenme gereksinimi gibi, yaşam-ortamı hakkında bilgi sahibi olmak; dünya hakkında "işlenmiş bir imaja" sahip olabilmek, insanların ortam hakkında güvensizlik duymadan yaşayabilmesi için vazgeçemedikleri bir 
gereksinimdir. Kişiler, bu işleri rastgele ve bölük-pörçük enformasyonlar alarak yapmamakta; bir inançlar ve faraziyeler karmaşası biçiminde; üstelik az çok keyfi nitelikte seçilmiş ve içsel bir görüş (vizyon) oluşturacak öğelerle yapmaktadır. Böylece kişi dış dünyasını bir oranda kendisince de betimlemek olanağı aramakta ve bulmaktadır (Oskay, 2000: 351).

Ball, Roeach ve De Fleur'e göre, toplumlar giderek daha karmaşık hale geldikçe, bireylerin içinde bulundukları daha geniş toplumsal dünya hakkında enformasyon edinebilmek için kitle iletişim araçlarına bağımlılıkları daha da artmaktadır. Bağımlılığın türü ve derecesi toplumun yapısal şartlarına ve toplumun bir değişme, çatışma ya da istikrarsızlık şartlarında bulunma durumuna göre değişiklik göstermektedir. İzleyicinin, okuyucunun kitle iletişim araçlarından edindiği enformasyona bağımlılı̆̆ ve böylece etkinin türü ve şiddeti (bilişsel, duygusal ve davranışsal), yapısal çatışma ve değişmelerin düzeyindeki artışa bağlı olarak daha da artmaktadır. Böylece kitle iletişim araçlarının rolleri nicelik, nitelik, güvenilirlik ve otorite bakımından toplumsal şartlara göre değişmektedir. Bağımlılık kuramı, insanların medyaya çeşitli bağımlılıkları olduğunu ve bu bağımlılıkların kişiden kişiye, gruptan gruba, kültürden kültüre değiştiğini belirtmektedir. Bu kuram medya, izleyici ve toplum üçlüsünün ilişkisi üzerinde durmaktadır (Gencer, 2012: 40-41).

Sistemin ve ideolojinin yeniden üretilmesinde büyük beceriyle donatılmış içerikler kitlelere sunulurken demokratik toplumların yönetimi de yavaş yavaş halkın ya da halkın temsilcilerinin elinden çıkar gruplarının ellerine kaymaktadır (Karadağ, 2000: 21). Kamuoyunun oluşumunda, bilgi verme işini yapan araçlar medya araçları olduğuna göre bu araçları kullananların, bilgilerin edinilmesi ve algılanmasında uyguladıkları yöntemler kamuoyunu yönlendirmek isteyenler için çok önemlidir. Belli çıkar grupları bireylerin düşünce ve tutumlarını etkilemek için medyayı kullanırlar. Kitle iletişim araçlarının önceliği, toplumun da önceliği edilir. Bu araçlar, bazı konuları öne çıkarıp onları önemli kılar ve bu şekilde kamunun oyu inşa edilir. Konu ile ilgili birçok araştırma da insanların kitle iletişim araçları tarafından etki altında bırakıldığını zaten göstermektedir (Yeğen, 2014: 24). Örneğin demokratik açık, kamusal alan açığı ve kimlik açığını gidermeye çalışan Avrupa Birliğinin inşa sürecinin mimarlarının gündeminde hep medyaya bu anlamda biçilen roller olmuştur. Medyadan kendileriyle ilgili konuları eş zamanlı ve türdeş bir şekilde işleyip yapının popülerleşmesine katkı sağlaması beklenmiştir (Karadağ, 2006: 200-201).

Kamuoyu oluşumundan söz edildiğinde genellikle medya etkilerinin üst aşamaları olan "tutum", "kanaat" değişimi ya da "davranış" değişikliğine vurguda bulunulmakta ve dolayısıyla medyanın "duygusal" ve "davranışsal" düzeydeki 
etkileri konu alınmaktadır (Yüksel, 2007: 571). Peki ama kanaatleri değiştirmek için medyayı kullananlar nasıl bir yol izlemelidir? Örneğin tartışmalı bir konuda kanaat değiştiriminde tek yanlı sunum mu yoksa iki yanlı sunum mu daha etkili olmaktadır? Yani sunduğumuz ve savunduğumuz ana tezimiz, eldeki delillerce açık bir şekilde destekleniyorsa, bu durumda, sadece savunduğumuz tezi destekleyen materyalleri savunmak m1, yoksa savunduğumuz teze karşı1 görüşte olanların savlarını da birlikte sunmak $\mathrm{m} ı$ daha iyi sonuç verecektir? Üzerinde çokça tartışılan bu konuyu aydınlığa kavuşturmak için bir araştırma yapılmış ve soruna yanıt aranmıştır. Sonuç olarak da şunlara ulaşılmıştır: 1) Karşıt görüşte olanlar üzerinde iki yanlı sunum, tek yanlı sunuma göre daha etkili olmuştur. 2) Savunulan görüşü zaten başlangıçta doğru bulanlar üzerinde ise iki yanlı sunum tek yanlı sunuma göre daha az etkin olmuştur. 3) İyi eğitim görmüş kişiler iki yanlı sunumdan, iyi eğitim görmemiş olanlar ise tek yanlı sunuma dayanan komünikasyondan daha fazla etkilenmiştir. 4) İki yanlı sunumun en az etkin olduğu gurubun, iyi eğitim görmemiş olup da başlangıçtan itibaren savunulan görüşe karşıt olmayan denekler olduğu saptanmıştır (Oskay, 1992: 234).

Bu tip araştırmalar medya aracılığıyla, insanları daha çok etkilemek, kanaatlerini ve tutumlarını değiştirmek isteyenler için yol gösterici olmuştur ve çeşitli yöntemler geliştirmelerini sağlamıştır. Gramsci'ye göre sadece siyasal alanda değil toplumun tüm alanlarında etkili olan egemen blok, özellikle 'popüler' bilgi ve kültürü kitlelerin katılımını güvenceye alacak şekilde geliştirmektedir (Akt. Özsoy, 2011: 63). Modern iletişim araçları maddi olarak yaşamlarını sağlayacak gelir düzeyine de ancak sınıfsal farklılıkların sınırlarını yok eden bir içerik üretimiyle ulaşabilmektedir. İletişim araçları böylece sokaktaki adama, ortalama yurttaşa seslenme gibi bir çözüm yolu bularak, en geniş hedef kitleyi oluşturduğunu varsaydığı halk kesimine ulaşmak için halkın dilini ve konuşma biçimini taklit etmektedir. Üstelik bu, farklı sınıflara seslenen tüm kitle iletişim araçlarının izlediği bir yol olarak görülmektedir. Hem üst kesimlere hem de alt kesimlere hitap eden kitle iletişim araçları arasındaki fark, içerik ve haber açısından farklılıklardan daha çok, sunum ve biçim farklılığı olarak karşımıza çıkmaktadır. Richard Hoggart'a göre kitle iletişim araçları okuryazarlığın kısmen azaldığ 1 dönemlerde yeni tip bir okuma-yazma bilmeme biçimi yaratmaktadır. Kitle iletişim araçlarının içerikleri alt kesimlerin kültür düzeyini yükseltmek şöyle dursun, okuryazarlık oranının arttığı bir dönemde varolan kültür düzeyini bile aşağılara çekmektedir (Tutal, 2006: 110-111). Bunda ortalama bir seviye tutturulmaya çalış1larak herkese hitap edilmesi ve daha çok kitleye ulaşmak isteği yatsa da; bu kez kültür düzeyi yüksek izleyiciler ya elden kaçmakta ya da bu tür programlara maruz kaldıkları için seviyeleri geriye çekilmektedir. Eğer ulaşılmak istenen amaç (Amerikan halkı için genellikle söylenen) kültür ve zekâ düzeyi aşağıda yönetilebilir bir halk kitlesi oluşturmak ise yöntem doğru bir yöntemdir. 
Televizyon programlarında seçilecek basit, gereksiz, saçma içeriklerle halk oyalanarak istenen amaca ulaşılabilinmektedir.

Kamuoyunun oluşumunda ilk aşama bilgi iletilmesi olduğuna göre, bu işlevi yerine getiren kitle için iletişim araçları büyük önem taşımaktadır. İkinci aşama ise iletilen bilgilerin alınması ve algılanması safhasıdır. Bu süreçte ise propaganda önemli bir rol oynamaktadır (Bektaş, 2013: 11). Tönnies'e göre propaganda, bir fikri doğruluk veya kesinliği ile bağlantısız olarak yaymak amaciyla kamuoyunun etkin bir biçimde uyarılmasıdır. Propaganda, özellikle siyasal alanda kamuoyunu etkilemek ve siyasal iktidarı ele geçirebilmek için kullanılmaktadır. Qualter'a göre de propaganda, bir bireyin veya grubun başka bireylerin veya grupların tutumlarını belirleyip biçimlendirmek, kontrol altına almak veya değiştirmek için haberleşme araçlarından yararlanarak ve bu bireylerin veya grupların belirli bir durum veya konumdaki tepkilerinin kendi amaçlarına uygun tepkiler şeklinde olacağını umarak giriştikleri bilinçli bir faaliyettir (Eke, 2008: 44).

Övgü miktarının kaliteyle ters orantılı olarak arttığını söyleyen Adorno ve Horkheimer'a göre ise propaganda insanları güdümler; özgürlük diye haykırdığg 1 yerde kendisiyle çelişir. Yalancılık propagandanın ayrılmaz bir unsurudur. Önder ile takipçilerin propaganda aracılığıyla bir araya geldikleri ortaklık, içeriği kendi içinde doğru olsa bile, yalan ortaklığıdır. "Hakikat bile taraftar kazanmak için salt bir araç haline getirilir; propaganda hakikati ağzına aldığında tahrif edilmiş olur" (Adorno ve Horkheimer, 2010: 340).

Chomsky ve Herman'a göre de medya kendisini denetleyen ve finanse eden güçlü toplumsal grupların çıkarlarına hizmet etmektedir ve onların lehine propaganda yapmaktadır. Bu çıkarların temsilcilerinin öne çıkarmak istedikleri önemli gündemleri ve ilkeleri vardır ve medya politikasının şekillendirilmesi ve dayatılması acısından oldukça elverişli bir konuma sahiptirler. Normal olarak bu, kaba müdahaleyle değil, uygun çizgide düşünen personelin seçilmesi, editörlerin ve çalışan gazetecilerin kurum politikasıyla uyumlu öncelikleri ve haber değeri kriterlerini içselleştirmeleri sayesinde başarılmaktadır (Herman ve Chomsky, 2012: 15).

\section{GÜNDEM BELİRLEME YAKLAŞIMI}

Zamanın belirli bir noktasında önemlilik sırasına göre dizilmiş sorunlar/konular ve olaylar listesine gündem denir (Atabek, 1997: 228). Gündem, gazetede ana sayfada geniş şekilde yer alan haberken, radyo ve televizyonda ise ilk okunan ve daha uzun süre ayrılan haberlerdir (Türkmen, 2014: 7). Gündem belirleme çalışmalarında, gündem kelimesinin ne anlamda kullanıldığına baktığımızdaysa; gündem belirlemenin, en genel seviyede konuların öneminin, medyadan 
izleyicilere geçiş olarak değerlendirildiği ve bu çalışmalarda da gündem kelimesinin, medya içeriğinde ve insanların bilincinde nesnelere gösterilen ilgi olarak tanımlandığı görülmektedir (Terkan, 2005: 42).

Bir konuyu gündeme neyin ya da nelerin getirdiği düşüncesi (bu ister medya, ister kamu ve ister siyasal gündem olsun), gündem belirleme alanındaki çalışmaların en temel sorusudur. Gündem belirleme yaklaşımına göre, insanlar ne hakkında düşüneceklerini ve konuşacaklarını medya aracılığıyla gelen mesajlardan öğrenmekte ve böylece oluşan gündemler siyasal gündemi şu ya da bu şekilde etkilemektedir. Bu da medyanın siyaset üzerindeki gücü şeklinde yorumlanmaktadır. $\mathrm{Bu}$ bakış açısıyla gündem belirleme araştırmaları aynı zamanda birer güç araştırmasıdır (Yüksel, 2001: 24-28).

Gündem belirleme yaklaşımının düşünsel temelini atan Walter Lippmann'a göre, insanlar kendi yakın çevreleri dışında olup bitenleri anlayabilmek ve doğrudan gözlem yapabilme olanağı bulamadıkları dış dünyayı kendileri için anlamlı hale getirebilmek için belli anlam haritalarına gereksinim duyarlar. $\mathrm{Bu}$ anlam haritaları da medyanın aktardığı bilgiler doğrultusunda oluşturulur. Gündem belirleme yaklaşımı, medyanın herhangi bir soruna verdiği önemin derecesinin, halkın aynı sorunlara verecekleri önemin derecesini belirlediğini öne sürer (İrvan, 2001: 70).

Maxwell McCombs ve Donald Shaw 1972'de kitle iletişim araçlarını elinde bulunduran medyanın bireyler üzerindeki etkisini ortaya koyan bir çalışma yapmışlardır. "Agenda settings" (gündem belirleme) adıyla ortaya koydukları bu teori, medyanın haberleri belli bir stratejide seçerek sunması ile kitlenin konuştuğu ve düşündüğü konuları belirlediği fikrine dayanmaktadır. McCombs ve Shaw kitle iletişim araştırmalarının daha çok tutum ve davranış değişikliği üzerinde durmuş olduğunu, ancak etkilerinin dört aşamada gerçekleştiğini belirtmişlerdir. Bunlar sırasıyla; farkında olma, bilgi edinme, tutum değişikliği ve davranış değişikliğidir. İlk aşama olan farkında olma aşamasında insanlar çevrelerinde olup bitenlerden haberdar olurlar. İkinci aşamada ise medya aracilığıyla çevresinde olup bitenlerin farkına varan bireyler bilgi edinmeye başlarlar. Üç ve dördüncü aşamalar tutum değişikliği ve davranış değişikliğidir (Akt. Türkmen, 2014: 2-7).

"Gündem belirleme" yaklaşımı kamuoyunun "farkına varma" ve "haberdar olma" boyutunda, medya etkilerinin ilk basamağını oluşturan, "bilişsel düzeydeki" etkileri konu almaktadır (Yüksel, 2007: 571). Gündem belirleme ya da gündem oluşturma belki de en anlaşılır tanımıyla; medyanın toplumun önceliğine, neyi bilmesi ve merak etmesi gerektiğine karar vermesi ile oluşturulan suni bilinç ve bu bilincin gerçek gündem halini almasıdır. Gündem belirleme, Atabek'in de işaret ettiği gibi, "Medyanın bir konuya ayırdığı yer ve zaman miktarının 
ölçülmesi gerektiğini ve bu ölçümün ya izleyicilerin konuya gösterdiği ilginin miktarıyla ya da onların konuların önemliliğine ilişkin yargılarıyla ilişkili olması gerektiğini söylemektedir." $\mathrm{Bu}$ anlamda gündem belirlemeye, "Medyanın ideolojik çabalarıyla oluşan meseleler" de denebilir. Gündem oluşturma, medya aracılığıyla toplumun bazı güncel sorunların görece önemini algılamasının temelini açıklamaya çalışan bir iletişim kuramıdır (Yeğen, 2014: 25).

Gündem belirleme tezine göre kitle iletişim araçları konular hakkında tutum değişiklikleri yerine "farkındalık" yaratır. Böylece önemli olan görüşlerin biçimlenmesinden çok, halkın ilgilendiği konular hakkında belli bir idrakin oluşmasıdır (Becker'den akt. Türkmen, 2014: 7). Gündem belirleme yaklaşımının iddiasına göre izleyiciler, medyada yer alan haberlerden sadece bazı gerçekleri öğrenmekle kalmazlar. Üstelik kitle iletişim aracının soruna veya konuya ayırdı̆̆ 1 yerin konumu veya zamanın miktarı ile o sorunun veya konunun ne kadar önemli olduğu yolunda çikarımlarda da bulunurlar. Gazete editörlerinin veya televizyon yayıncılarının gündelik işlerini yaparken yayınlanacak haberleri seçmesi ve haberlerin gazete veya televizyondaki konumlarını belirlemesi, izleyicilerin dünyayı algılayış biçimleri üzerinde önemli etkiler yapar (Atabek, 1998: 156). Kamuoyunu ilgilendiren hiçbir konu (politika, haber, eğitim, din, bilim, spor) televizyonun ilgi alanının dışında kalamaz. Yani halkın bu konuları kavrayış biçimi tamamen televizyonun yönelimleriyle şekillenmektedir (Postman, 2012: 91).

"Medya insanların ne düşünmeleri gerektiğini söylemede çoğu kez başarılı olmayabilir" diyen

Bernard Cohen, kitle iletişim araçlarının insanların ne hakkında düşüneceklerine karar verdiklerini söyleyerek asıl üzerinde düşünülmesi gereken konunun da bu olduğuna dikkat çekmektedir (Türkoğlu, 2004: 110). Cohen'e göre buradan yola çıkarak söyleyebiliriz ki, dünya farklı insanlara farklı şekillerde görünür. $\mathrm{Bu}$ farklılıkları sadece kişisel ilgiler değil, okunan gazeteler tarafından çizilen haritalar da yaratır (İrvan, 2001: 70).

Gündem belirleme yaklaşımında, kitle iletişim araçlarının siyasal bilgiler vermek için kullanılışı ile araçların üzerinde durduğu konuların önemli hale gelmesi arasında pozitif bir ilişki olduğu öne sürülmektedir. Yani bireyin siyasal konulara yönelme düzeyi, kitle iletişim araçlarının siyasal bilgi için kullanılmasıyla pozitif bir ilişki içindedir. Daha açık bir ifadeyle kitle iletişim araçlarının konulara verdikleri öncelikler, izleyiciler tarafından öğrenilir. Bu farkında olmadan daha öte bir şeydir. Kitle iletişim araçlarının öncelikleri halkın öncelikleri olur (Akt. Türkmen, 2014: 7). Bu bağlamda bakıldığında Türkiye'deki televizyonlardaki 
siyasal içerikli haber programların ağırlıklı olması nedeniyle halkın da siyasal konulara ilgisinin yüksek olduğu söylenebilir. Ancak bu durumun da geçmişe oranla azalmaya başladığı, ABD televizyonlarındakine benzer şekilde siyasal içeriklerin azaltılmaya çalışıldığı iddia edilmektedir.

Konuların ya da sorunların kamuoyunun gündemine nasıl girdiği ve gündemden nasıl çıktığı araştırmacıların uzun yıllardır üzerinde çalıştığı bir konudur. Gündem belirlemeye göre kamu gündeminde (izleyicilerin gündeminde) yer alan konular ve bu konuların önemlilik sıraları medya gündemi tarafından belirlenmektedir (Atabek, 1997: 231). Gündem belirleme hipotezinin en genel varsayımı, gelişen olay ve mevcut durumlara bağlı olarak kitle iletişim araçlarının bunlardan bazılarına ilgi duyarak önem vermesi, bazılarını da göz ardı ederek bunlara düşük önem göstermesi veya önem göstermemesi durumunda bilgi ihtiyacını karşılamak üzere medyayı takip eden bireyi, konuların önem düzeyine ilişkin etkileyebileceği düşüncesidir. Olası fikir etkileriyle birlikte medyadan gelen tüm etkileri içinde barındıran da, büyük oranda medyadan bireye akan enformasyondur. Enformasyon, bireye konunun önemine ilişkin çeşitli ipuçları vermektir. $\mathrm{Bu}$ değerlendirme ile hipotez, medyanın en çok ilgi gösterdiği ve yer ayırdığı konunun birey tarafından en önemli konu olarak algılandığını ve bu konunun bireyin kişisel gündemine yerleştiğini öngörmektedir (Kamanlığlu, 2007: 29). Bazen bir cinayet günlerce, hatta haftalarca gündemde tutulabilmekte. Ya da uluslararası bir konu özellikle, ulusal konuların gündemde az yer alması adına medyada daha çok yer sahibi olabilmektedir. Bunları iyi anlayabilmek için, yani bu konuların neden gündemde tutulduğunu anlayabilmek için de tüm gündemi farklı kaynaklardan ve çok sıkı bir şekilde takip etmek gerekmektedir.

Gündem belirlemenin kamu politikası üzerindeki etkisini inceleyen Peter Mortensen, yasal düzenlemeler, akıllı politika girişimcileri, teknik gelişmeler, yenilenen politika imajları, toplumsal ruh hali, olaylara odaklanma şekli ve medya gibi unsurların gündem üzerinde etkili olduklarını belirtmiştir. Gündem belirleme sürecini, medya, kamu ve siyasal gündem üçlüsüne "gerçek dünya faktörleri"ni de katarak bunlar arasındaki ilişkiyi sorgulayan Stuart Soroka, 1985 ile 1995 arası Kanada basınında yer alan gazeteler üzerinde içerik araştırması yapmıştır. Kavramlar arasındaki çok yönlü ilişkiyi inceleyerek gündem belirlemenin gelecekte bulunacağı olası etkileri öngörebilmek adına modellemeler yapmıştır. $\mathrm{Bu}$ modellemeler gündem belirlemenin boyutlarının fazlalığının göstergesidir (Akt. Göçoğlu ve Aydın, 2015: 890). Soroka, gündem belirleme için yeni bir konu sinıflanması önermektedir. Bunlar; göze çarpan konular, sansasyonel konular ve hükümetsel konulardır. Buna göre: 
- Göze çarpan konular, çok sayıda bireyin ilgisini çeken, somut ve dünya gerçeklikleri dolayısıyla oluşan konular olup, öğrenilmesi sürecinde medya veya politika etkisine çok fazla yer bırakmayan konulardır.

- Sansasyonel konular, göze çarpan konular gibi somut ve doğrudan öğrenilebilen konular olmasına rağmen, bireylerin büyük bir çoğunluğu üzerinde çok az gözlemlenebilir bir etkiye sahiptir. Sansasyonel konular, medya tarafindan kamu gündemi oluşturma bakımından en büyük potansiyele sahiptirler (Terkan, 2005: 47).

- Hükümetsel konular ise siyasal alandaki seçilmiş, bürokrat ya da kurumlardan kaynaklanan ve medya gündemiyle kamu gündemi üzerinde ikincil etkilere sahip konulardır. Bireyler tarafından doğrudan öğrenilmeyen bu tür konular için Soroka, politik gündemin medya ve kamu gündemini etkilemesi durumundan söz etmektedir (Akt. Kamanlıŏglu, 2007: 39).

Gündem belirleme kuramının temelini daha çok siyasal olaylar, özellikle seçimler ve seçim kampanyaları oluşturur. Bu sayede siyasal seçkinler medya aracıllğıyla toplumun gündemini belirlemiş olurlar. Siyasal kampanyalarda hangi konunun önemli olduğu medya tarafından gündeme getirilirse, o konuda en girişken olan adayın (veya siyasal partinin) seçmenlerin oyunu alacağına inanılır. Bu noktada gündemin belirlenişs şekli ya da neyin gündem olup neyin olmayacağı medya patronları ve siyasal seçkinlerin ikili ilişkilerine göre değişebilmektedir. Özellikle farklı alanlarda da ticari faaliyetler içerisinde bulunan medya patronları gündemin oluşmasında önemli rol oynamaktadır. Kısaca gündem belirleme yaklaşımına göre medyanın önem ve yer verdiği konular, izleyicilerin gündemini oluşturacak ve onların gündemini meşgul edecekken, medyanın yer vermediği konular halkın ve izleyicilerin gündemine gelmeyecektir (Akt. Ergen, 2014: 3).

\section{MEDYANIN GÜNDEM BELIIRLEME GÜCÜ}

Medyanın esas gücü, dünya görüşümüzü şekillendirebilmesi, düşünce ve fikirlerimizin temel kaynağı olabilmesi ve davranış biçimimizi değiştirebilmesidir. Onu televizyon gibi kişisel bir araç olarak değil de, bir bütün olarak ele aldığımızda, bu gücü daha açı bir şekilde görebiliriz (Burton, 2008: 14). Kitle iletişim araçlarına bağlanan bireyler, toplumun gündeminde nelerin olduğunu belirlemek için televizyon, gazete, internet gibi kitle iletişim araçlarına yönelmektedir. Bunun neticesinde bireyler kitle iletişim araçlarının etkilerine maruz kalarak, bilerek ya da bilmeyerek zihinsel, duygusal ve davranışsal etkiler oluşturmaktalar. Oluşan bu duygusal efekt ve etkiler de insanların ve doğal olarak da toplumların gündemlerini yönlendirmektedir (Gencer, 2012: 40-41). 
Her gün dünyada savaşlar, isyanlar, tüketiciyi dolandırmalar, yarışmalar, aile içi şiddet, bilimsel gelişmeler, politik demeçler ve insan sevinçleri ve kederleri yaşanmaktadır. Haber medyası elbette bütün bu olayları yayına koyamaz (ve koymaz). Yapılan hesaplamalara göre günlük bir gazete potansiyel haberlerin \%75'ini reddeder ve asla yayınlamaz. Ülke genelinde yayın yapan medyada, mesela büyük televizyon kanallarında geri çevrilen haber yüzdesi çok daha fazladır. Söz gelimi her gün dünyada bir sürü silahlı çatışma yaşanmaktadır. Haberleri seyredenler veya günlük gazeteyi okuyanlar bu haberlerden yaklaş1k iki üç tanesini öğrenir ve yıllardır seyredip okuduktan sonra muhtemelen bir düzineden daha az savaşın ismini hatırlayabilir (Pratkanis ve Aronson, 2008: 312).

Uluslararas1 habercilikte, hangi ulusal haberlerin uluslararası gündemi oluşturacağında genellikle ulusal basın gündemleri belirleyici olmaktadır. Uluslararası haber olarak adlandırılan şeyse, bir ulusal medya uzamından diğerine farklılık göstermektedir. Bu tip haberler coğrafi-politik ve kültürel çıkarlar uyarınca bir ülkeden diğerine farklılık gösteren haber tanımlarına göre değişiklik göstermektedir. Uluslararası politik ve ekonomik güç ilişkilerindeki dönüşümler uluslararası haber gündemini de belirlemektedir. Uluslararası haberlerin üretiminde politik çekişmeler ve ekonomik çıkarlar belirleyici bir rol oynamaktadır (Tutal, 2006: 158-159). Dost gördügünüz ülkeden olumlu haberleri kendi ulusal medyanıza taşırken olumsuz haberleri görmezden gelmek, ya da düşman ülke ile ilgili olarak sürekli olumsuz haberleri gündeme taşımak gibi.

Günümüzde ulusların ve halkların algısını yönlendirme çabaları eskisine göre daha kolay hale gelmiştir. Bugün dünyada 4 milyar radyo, 1,4 milyar televizyon alıcısı bulunmaktadır. Büyük ülkelerin başlıca radyo ve televizyon yayınlarının dünyada ulaşmadığı insan sayısı çok azdır. CNN mümkün olduğu kadar geniş kitlelere ulaşmak için Türkçe, İspanyolca, Arapça, Hintçe Japonca gibi çok sayıda dilde yayın yapmaktadır. El Cezire kanalı önemli bölgelerde yerel dillerle yaptı̆̆ 1 yayınlarla etkilidir. İngiliz BBC radyosu da 69 dilde yayın yapıyordur. Bu olanaklardan yararlanarak, devletler kendi hedefleri doğrultusundaki görüşlerini dünyanın çeşitli bölgelerindeki halklara ulaştırabilmektedir. $\mathrm{Bu}$ gelişmeler önemlidir, ancak büyük devletler için yeterli değildir. Soğuk savaş bittikten sonra yabancı gazetecileri ikna etmek daha zorlaşmıştır. Büyük devletler için, dünyanın çeşitli meselelerine yabancı gazetecilerin onların gözlükleriyle bakabilmeleri sağlanmalıdır. Bu sürekli işleyen bir mekanizma olmalıdır ve dünyanın her yerinde etkisini göstermelidir. Etkilenmek istenen gazetecilerden en çok beklenen de, yazacakları yazıları, radyo ve televizyonlarda yapacakları programlarla halkın düşüncelerini büyük devletlerin hükümetlerinin beklentileri doğrultusunda yönlendirmektir (Öymen, 2014: 375). Büyük devletlerin, kendi ülkelerinin 
çıkarları doğrultusunda gündem oluşturabilmesi ve propaganda yapabilmesi için öncelikle yabancı ülkelerdeki gazetecilerin etkilenmesi gerekmektedir. $\mathrm{Bu}$ devletler, gazetecileri yönlendirmek ve haber seçimlerinde etkili olabilmek içinse çeşitli yöntemler geliştirmişlerdir.

Büyük devletlerin siyasetçileri ve diplomatları, dış politika alanında yabancı gazetecileri kendi ülkelerinin politikaları doğrultusunda etkilemeye çalışırken, öncelikle telkin ettikleri görüşlerin aslında o yabancı gazetecinin ülkesinin menfaatlerine uygun olduğunu söyleyerek onları etkilemeye çalışırlar. Önemli yabancı gazetecilerin ikna edilmesinin en etkili yollarından biri, gazetecilerin çeşitli toplantılara katılma vesilesiyle yabancı ülkelere davet edilmeleridir. Bilderberg toplantıları da bunların içinde en önemlisidir. Önemli ve gündem oluşturabilecek maharetteki gazetecileri etkilemenin diğer bir yolu ise dünyanın önemli liderlerinin, dışişleri bakanlarının ve diğer ünlü kişilerinin seçilmiş bazı yabancı gazetecilere özel mülakatlar vermelerinin sağlanmasıdır. Bu da o gazeteciler açısından mesleki olarak bir başarı sayılacaktır. O gazeteciler de, ileride böyle önemli firsatları kaçırmamak için yazılarında veya televizyon programlarında o ülkeleri veya o liderleri karşılarına alacak kuvvetli eleştiriler yapmaktan kaçınacaklardır. Seçilmiş gazetecilerin sık sık büyükelçiliklere ve başkonsolosluklara davet edilmeleri ve onlara özel bilgiler verilmesi de uygulanan yöntemler arasındadır. Şu veya bu şekilde etkilenen gazetecilerden beklenenlerin başında ise haberlerin seçimi gelmektedir (Öymen, 2014: 375-380). İç politikada da benzer uygulamaların yerel siyasetçiler tarafından kullanıldığı görülmektedir. Etkili olabilecek gazetecilere açıklamalar yapılması, davetlere çağrılması, gezilere götürülmesi vb.

Sanayi toplumunda bilginin üretilmesi ve paylaşılması hemen hemen her ülkede medya kartellerinin kontrolünde gerçekleşmiştir. Ancak bilgi toplumuna geçişle, teknolojik gelişmelerle, kitle iletişim araçlarının kullanımının tabana yayılmasıyla (blog, kişisel siteler) bilgi kaynağ 1 çeşitliliği ve bireysel tecrübelerin çok kolay ve hızlı bir şekilde aktarımı sağlanmıştır (Eren ve Aydın, 2014: 197). Kamu politikasının bir gündem oluşturması ve oluşan bu gündem itibariyle halk kanaat ve tutumunun oluşmasında artık sosyal medyanın büyük bir rolü vardır. Sosyal medya terimi, internet kullanıcılarının birbirileriyle bilgi, görüş, ilgi alanlarını, yazılı görsel ya da işitsel bir şekilde paylaşarak iletişim kurmaları için olanak sağlayan araçlar ve web sitelerini içermektedir. Sosyal ağ siteleri ve programlarının gelişim süreci, sosyal medyanın gelişiminde doğrudan etkiye sahiptir. Fotoğraflar, ses dosyaları, videolar gibi görsel ve işitsel öğeleri son derece kaliteli bir şekilde kaydedecek duruma gelen mobil cihazlar (akıllı telefonlar, cep bilgisayarları, tabletler vb.) sosyal medya platformlarındaki içerik paylaşımını kolaylaştırmakta ve hızlandırmaktadır. Bu gelişmeler, sosyal medya platformlarının "birbirine 
bağl1l1k" özelliği ile birleşerek sosyal medya oluşumunu daha güçlü bir hale getirmektedir (Göçoğlu ve Aydın, 2015: 886-889).

2018 itibariyle dünya nüfusunun \%53'ünün, yani 4.02 milyar kişinin internet bağlantısı bulunmaktadır (url1). Sadece Amerika'nın etkili yayın kuruluşu CNN'in Twitter hesabına abone olanların sayısı 40.9 milyon kişidir. Geleneksel medya ve iletişimde, politika üreticilerine ulaşma şansı daha çok elit bir kesimin elinde iken, sosyal medya ile bu şansı her sosyal medya kullanıcısı yakalamıştır. Sosyal medyanın geleneksel medyaya göre daha pratik ve iletişim için az zaman gerektiren bir oluşum olması da bunda etkilidir. Sosyal medyayı geleneksel medyanın (tv, gazete, radyo) alternatifi olarak gören internet kullanıcıları, sosyal medyanın, ana akım medyada yer verilmeyen haberlere ulaşmalarını sağladığını belirterek, sosyal medyanın kitleleri harekete geçirme gücüne dikkat çekmektedirler (Göçoğlu ve Aydın, 2015: 889). Amerikalı yazar Henry David Thoreau, 1849 yılında yazdığı Sivil İtaatsizlik isimli makalesiyle ilk kez ortaya koyduğu kavramla, kitlelerin yönetimin koyduğu yasalara uymadan yaptığı eylemleri sivil itaatsizlik olarak tanımlamıştır. Sivil itaatsizlik olarak görülen toplumsal eylemlerinse son yıllarda özellikle sosyal ağlar üzerinden örgütlendiği göze çarpmaktadır. Sosyal ağların politik katılıma etkisini ilk kez gösteren bu eylem girişimlerinin ilk örnekleri; 2011'de Amerika'nın finans merkezi olan New York'taki Wall Street olayları, 2011 yılında İspanya'daki Indignados (öfkeliler), İngiltere'deki Londra ayaklanması ve 2010 yılında başlayan “Arap baharı” olarak adlandırılan toplumsal hareketlerdir. Türkiye'den de Taksim Gezi Parkı olayları sosyal medya aracılığıyla örgütlenerek gerçekleştirilen eylemlere örnek olarak gösterilmektedir (Akt. Türkmen, 2014: 9).

Herman ve Chomsky'e göre ise muhaliflerin ve protestocuların iletişim donanımına değerli bir katkı sağlamış olmasına rağmen, kritik bir araç olarak internetin yine de sınırlılıkları vardır. Bir kere, internet bilgiye ihtiyaçları en yoğun olanlara yeterince hizmet etmez -pek çok kişinin erişim sorunu vardır ve genelde internetin etkili bir şekilde kullanılması önceden belli bir bilgiyi ve organizasyonu gerekli kılar (Herman ve Chomsky, 2012: 20). Ayrica yeni medyada eşik bekçisi görevi görecek kişilerin olmaması nedeniyle kamuyu yalan ya da yanlış haberlerle yönlendirmek de mümkün olmaktadır.

Kitle iletişim araçlarının hızla gelişip yaygınlaştı̆̆ demokratik ülkelerde insanların çoğunun basını, radyo ve televizyonları güvenilir haber kaynağı olarak gördükleri bir çağda, bazı haberlerin hükümetler, ticari kuruluşlar veya menfaat grupları tarafından etkilenen gazeteciler aracılı̆̆ıyla üretildiği, haber değeri olmayan bazı hususların aynı yollarla yayınlandığı, gerçekten haber yapılması gereken bazı konuların ise üstünün örtülerek halka ulaştırılmadığının örnekleriyse maalesef ki çok fazladır (Öymen, 2014: 383). 
İletişim araçlarına erişim, iktidarı kullanma ve toplumsal kontrolü sağlamanın da bir aracıdır. Buna özellikle kitle iletişim araçları bağlamında inanılmaktadır: örnekler bulmak için otoriter hükümetlerin ve diktatörlerin iletişim araçlarıyla ilişkilerine bakmak ya da başarılı devrimci güçlerin ilk hedeflerinin ulusal radyo istasyonları olduğunu göz önüne getirmek yeterli olacaktır (Fiske, 2015: 105). Kitle iletişim araçlarına sahip olma ya da onlardan yararlanabilme durumu hem halkın kanaatlerini biçimlendirmede hem de araç sahiplerinin kanaatlerine etkide bulunmada büyük öneme sahiptir. Yeni olaylar hakkında kanaat oluşturma ya da eski kanaatleri değiştirme gücüne sahip olan iletişim araçları, oluşturdukları gündemlerle kamuoyunun biçimlenmesine önemli etkide bulunmaktadır (Ertaş, 2000: 45).

\section{TÜRKIYY'DE GÜNDEM BELİRLEME ÇALIŞMALARI}

Türkiye'de günümüzde medya ve kamu gündemini belirleyen unsurların başında siyasal gündemin geldiği görülmektedir. Önceleri medya gündemi, siyasal gündemi belirlemede daha etkiliyken, şimdilerde siyasal gündem, medya gündemini ve dolayısıyla kamu gündemini belirlemede daha etkili konumdadır.

Rızanın örgütlenmesi olarak özetlenebilen hegemonya, şiddet ya da zora başvurulmadan inşa edilen bilinç biçimlerinin inşa sürecini ifade ettiğine göre (Özsoy: 2001: 63), yönetenlerin de bu inşa sürecini gerçekleştirmedeki en etkili araçlardan olan medyayı kullanma çabaları anlaşılır bulunmaktadır. Medyanın gündem belirleme ve kamuoyu oluşturma gücünün farkında olan politikacılar ve çıkar sahipleri, gazetecileri etkileme yollarını ve medyayı yönetme yollarını aramakta ve bulmaktadır. Dördüncü güç olarak gösterilen medya da, güçler ayrımı ilkesinden uzaklaşılmasıyla birlikte diğer güçler gibi siyasaya yaklaşmıştır. Siyasal gündemin, medya ve kamu gündemini yönlendirmesinde etkili olan faktörlerin başında ise kültür endüstrisini ve yaratımlarını iyi kavramış, bilinçli ve güçlü yöneticilerin olduğunu söylemek mümkündür.

Medyanın son dönemlerde bazı konularda gündem oluşturmadaki yetersizliği veya isteksizliği dikkat çekicidir. Örneğin Türkiye'de 2016 yılında kalıcı yaz saati uygulamasına geçilmiş, ancak halk tarafından tepki çekmesine rağmen çok fazla gündeme getirilmemiştir. Kamu gündeminde önemli bir yer tutan kış saati uygulamasına geçilmemesi ve dolayısıyla insanların sabah hava karanlıkken işlerine ve okullarına gitmeleri, medyanın gündeminde çok az ve alt sıralarda yer bulmuştur. Ulusal muhalif medyada yapılan 3-5 haber sonrası siyasilerden ufak bir açıklama gelmiş, ancak siyasal gündemde kendine yer bulamamıştır. $\mathrm{Bu}$ haberlerin, özellikle televizyonda ana haber ve gazetede manşet gibi, daha geniş bir şekilde ve uzun bir süre medya gündeminde ilk sırada yer alması durumunda, siyasilerin ve siyasal gündemin konuya ilgisiz kalamayacağı bir gerçektir. Ancak 
medya kuruluşlarındaki haber seçimlerinde etkili olan sistem, siyasal gündemin de tercih etmediği bu konulara ilgi göstermemeyi tercih etmiştir.

Türkiye'deki gazetelere baktığımızdaysa, büyük çoğunluğunun çeşitli toplumsal grupların görüşlerini tek yanlı olarak yansıtan medya organları olması nedeniyle eskiye oranla gündemde önemli bir etkiye sahip olduklarını söylemek zordur. Ancak kendi dar çevrelerindeki gündemi belirlemede etkili olmakta, siyaset ve kamu gündemini belirlemekte yetersiz kalmaktadır. Birçok gazetede haberlerin tek yanlı olarak sunulması, sürekli olarak aynı görüşe yer verilmesi, diğerlerinin ise yok sayılması, gazetecilik etiği açısından doğru olmasa da o gazeteyi okuyanlar zaten o görüşü baştan destekleyen kişiler olduğu için yayıncılar açısından okuyucuların kafasını hiç karıştırmamak doğru bir yöntem olarak görülmektedir.

Ana akım medyaya alternatif olarak gösterilen sosyal ağlar ise özellikle çeşitli ülkelerin ve grupların provokatif kullanımları nedeniyle başlardaki etkiyi yaratmaktan çok uzaktır. Sosyal medyada örgütlenen kimi grupların çıkardığı olaylar bir dönem o kadar büyük boyutlara ulaşmıştır ki medyanın gündeminde de ilk sıralara çıkmış ve kamu gündemini çokça meşgul etmiştir. Ancak siyasi gündemin uzak durma çabaları sonucu medya gündeminden de düşmüştür. Yine de gündem belirlemede sosyal ağların belli bir etkiye sahip olduğu görülmektedir. Örneğin Twitter aynı zamanda diğer medya organları için de bir kaynak durumundadır. Özellikle önemli kişilerin paylaşımları anında televizyon, gazete gibi diğer medya ortamlarında haber yapılmaktadır. Örneğin Bahçeli'nin Twitter paylaşımları ana haber bültenlerinde birkaç kez ilk haber olmuş ve gündemi oluşturmuştur.

Türkiye'deki yabancı ortaklı kimi televizyon kanallarına göz attığımız da ise bunların ulusal sermayeli kanallara göre biraz daha farklı yayıncılık yaptıkları görülebilmektedir. Büyük devletlerin çıkarları doğrultusunda, onların yerel siyasetçilerle olan ilişkileri ve çekişmelerine göre haber seçimlerinin yapıldığ 1 ve gündemin belirlendiği izlenebilmektedir. Dolayısıyla Türkiye'de bazen iç bazen de dış güç odakları sayesinde medyanın gündemi belirlenmektedir. Medyada gündem belirlemede en önemli etkiyi yaratan faktörün de güç ve ilişkiler olduğunu söylemek mümkündür.

\section{SONUC}

Medyanın gündem belirleme ve kamuoyu oluşturma gücü her zaman oldukça fazla olmuştur. Medyanın gündemini belirlemek ise her zaman siyasiler, çıkar grupları, sermaye çevreleri ve küresel güç dengeleri için bir hedef olarak görülmüştür. Büyük devletler bazen açıtan bazen gizliden destek verdikleri medya gruplarını; yönetmek ve gündemini kontrol altında tutmak istedikleri ülkelerde faaliyete geçirmiş ve kendi çıkarları doğrultusunda yayın yapılmasını sağlamışlardır. 
Medya, kamu ve siyaset gündemi ise kendi aralarında birbirlerinin gündemlerini etkileme mücadelesinde üstünlük kazanma çabası içinde olmuştur.

Bir toplum içinde yaşayan insanların belli bir olgu ya da inanç üzerinde ortak yargı oluşturması olarak tanımlanan kamuoyunu etkileme çalışmaları, medyayı yönetmek ve gündem belirlemekle başlamaktadır. Medyaya haber oluşturanlar gazeteciler olduğuna göre de öncelikle gazetecilerin ve medya yöneticilerinin etkilenmeleri, böylelikle haber seçimlerinde daha dikkatli olmaları sağlanmaya çalışılmaktadır.

Türkiye'de medyanın, siyasetin gündemini belirleme gücü eskiye göre biraz daha azalmış görünmektedir. Daha çok siyasal gündemin ve siyasilerin medyanın ve kamunun gündemini belirlediği izlenmektedir. Bunda ekonomik-siyasal ilişkiler, medyadaki güç dengeleri ve ideoloji önemli rol oynaktadır.

Medyanın ürettiği kitle kültürü içinde homojenleşen, edilginleşen kamunun da kendi gündemini oluşturması güçleşmektedir. Kamuyu oluşturanlar medya gösterileri ile o kadar çok zaman harcamaktadır ki medyanın gösterdiklerini kendi gündemi sanmakta ve benimsemektedir. Ya medyanın sunduğu kitlesel eğlence ile uyuşturulmakta ya da genelde siyasal gündeme hizmet edecek (egemen veya muhalif) haber akışlarına maruz kalmaktadırlar.

Kamunun çıkarlarını korumakla görevli olan gazetecilerin ya kendi ya da yöneticilerinin çıkarlarını koruması, kamunun gerçek gündeminin ve sorunlarının medya içeriklerinde görmezden gelinmesi ise kamuda yalnızlık, çözümsüzlük ve umutsuzluk hissini artırmaktadır. Kamu, bazen diğer gündem maddelerine o kadar yoğun olarak maruz kalmaktadır ki, kendi gündeminin ne olduğunu unutmaktadır. Kültür endüstrisinin halkı eğlence ve başka boş zaman etkinlikleriyle oyalayarak uyutmasında olduğu gibi gazeteciler de, gündem belirlerken, halkı içi boş gündem maddeleri veya eğlenceli görüntüler ile edilginleştirmektedir.

İkinci aşama gündem belirleme araştırmalarında medyanın, kamunun "ne hakkında düşüneceğini" belirleme yönündeki geleneksel gündem belirleme hipotezi, "ne düşüneceğini" ve "nasıl düşüneceğini" de belirleme yönünde yeni bir açılım sağlamaktadır (Yüksel, 2007, s.581). Günümüzde ise bu aşama da geçilmiş, son aşama olan davranış değişikliğinin nasıl olacağı net bir şekilde anlatılmakta ve belirlenmeye çalışılmaktadır.

Gündemi belirlemenin yaşamsal bir boyut halini aldığg çağımızda belirtilmeyen, dile gelmeyen konu ve görüşlerin kültürden düşmesinde olduğu gibi, konuşulmayan, dile getirilmeyen, üstü örtülen, gündeme getirilmeyen her konu zamanla kamunun da gündeminden düşmekte, etkisi azalmakta ve yok olmaktadır. 


\section{KAYNAKÇA}

Adorno W.T. ve Horkheimer, M. Aydınlanmanın Diyalektiği. 1. bask1, N. Ülner ve E. Öztarhan Karadoğan (çev.), Kabalcı Yayınevi, İstanbul, 2010.

Adorno, W.T. Kültür Endüstrisi Kültür Yönetimi. 7. bask1, N. Ülner, M. Tüzel ve E. Gen (çev.), İletişim Yayınları, İstanbul, 2012.

Atabek, N. Gündem Belirleme Araştırmalart. İstanbul Üniversitesi İletişim Fakültesi Dergisi, Sayl: 5. 223-247, 1997.

Atabek, N. Gündem Belirleme Yaklaşımı. İstanbul Üniversitesi İletişim Fakültesi Dergisi. Sayl: 7. 155-174, 1998.

Bektaş, A. Kamuoyu, İletişim ve Demokrasi. 4. baskı, Bağlam Yayıncılı, İstanbul, 2013.

Burton, G. Görünenden Fazlası. 1. basım. N. Dinç (çev.), Alan Yayıncılık, Istanbul, 2008.

Eke, E. Siyasal Propaganda Araçlarının Seçmen Davranışı Üzerindeki Etkisi: Isparta Örnek Olayl. Süleyman Demirel Üniversitesi Sosyal Bilimler Enstitüsü Kamu Yönetimi Anabilim Dalı Yüksek Lisans Tezi. Danışman: Yrd. Doç. Dr. Cemal Baltacl, 2008.

Eren, V. ve Aydın, A. Sosyal Medyanın Kamuoyu Oluşturmadaki Rolü ve Muhtemel Riskler. Karamanoğlu Mehmetbey Üniversitesi (KMÜ) Sosyal ve Ekonomik Araştırmalar Dergisi 16 (Özel Sayı I): 197-205, 2014. ISSN: 2147-7833.

Ergen, Y. Gündem Belirleme Kuramı Bağlamında Yeni Medya: Twitter Gündemi Hakkında Karş̧laş̧ırmalı Bir Analiz. Marmara Üniversitesi Sosyal Bilimler Enstitüsü. 2014. https://www.academia.edu/8578057/

Fiske, J. Popüler Kültürü Anlamak. 1. baskı, S. İrvan (çev.), Parşömen Yayıncılık, Istanbul, 2012.

Fiske, J. İletişim Çalışmalarına Giriş. 4. bask, S. İrvan (çev.), Pharmakon Yayınevi, Ankara, 2015.

Freud, S. Kitle Psikolojisi. 7. basım, K. Şipal (çev.), Cem Yayınevi, İstanbul, 2015. Gencer, Z.T. Medyanin Gündem Oluşturma Sürecinde Sosyal Entropinin Rolü Üzerine Uygulamalı Bir Çalışma. Selçuk Üniversitesi Sosyal Bilimler Enstitüsü Halkla İlişkiler ve Tanıtım Anabilim Dalı Araştırma Yöntemleri Bilim Dalı, Doktora Tezi, Danışman: Doç. Dr. Mustafa Özodaşık. Konya, 2012.

Gö̧̧ŏ̆lu, V. ve Aydın, M.D. Kamu politikast ve sosyal medya ilişkisinin toplumsal hareketler bağlamında incelenmesi. Uluslararası Sosyal Araştırmalar Dergisi, 8(37): 880-901, 2015. ISSN: 1307-9581. 
Gönenç, E. Ö. (2002). Kitle Kültürü ve Kitle İletişimi. İstanbul Üniversitesi Iletişim Fakültesi Dergis. 13: 129-138, 2002.

Herman, E. S. ve Chomsky, N. Rızanın İmalatı Kitle Medyasının Ekonomi Politiği. 2. baskl, E. Adaboğlu (çev.), bgst Yayınları, İstanbul, 2012.

İrvan, S. Gündem Belirleme Yaklaşımının Genel Bir Değerlendirmesi. Gazi Üniversitesi İletişim Fakültesi Dergisi. İletişim Kuram ve Araştırma. 9: 69-106, 2001.

Kamanlıoğlu, E. B. Politik Gündem Oluşumunda Halkla İlişkilerin Isşlevi. Ege Üniversitesi Sosyal Bilimler Enstitüsü Halkla İlişkiler ve Tanıtım Anabilim Dalı Yüksek Lisans Tezi. Danışman: Prof. Dr. Aylin Pira. İzmir, 2007.

Karadağ, G.H. (2000). TV Haber Programcllı̆̆l ve Bir Örnek: 32.Gün. İstanbul: Etika Yayıncilık.

Karadağ, G.H. (2006). AB'nin Medyası Medyanın AB’si. İstanbul: Güncel Yayıncillk.

Kellner, D. Medya Gösterisi. 1. baskı, Z. Paşalı (çev.), Açıllımkitap Yayınları, Istanbul, 2010.

Oskay, Ü. Kitle Haberleşmesi Teorilerine Giriş. 4. bask1, Der Yayınları, İstanbul, 1992.

Oskay, Ü. Kitle İletişimin Kültürel İşlevleri. 4. baskı. Der Yayınları, İstanbul, 2000.

Oskay, Ü. Yıkanmak İstemeyen Çocuklar olalım. 8. baskı, Yapı Kredi Yayınları. Istanbul, 2013.

Öymen, O. Bir Propaganda Silahı Olarak Basın. 2. bask1. Remzi Kitabevi, Istanbul, 2014.

Özsoy, A. Televizyon ve İzleyici. 1. baskı. Ütopya Yayınevi, Ankara, 2011.

Postman, N. Televizyon: Öldüren Ĕ̆lence. 4. baskı. O. Akınhay (çev.), Ayrıntı Yayınları, İstanbul, 2012.

Pratkanis A. ve Aranson, E. (2008). Propaganda Çağı. 1. baskı, N. Haliloğlu (çev.), Paradigma Yayıncılık, İstanbul, 2008.

Swingewood, A. (1996). Kitle Kültürü Efsanesi. 1. bask1. A. Kansu (çev), Bilim ve Sanat Yayınlarl, Ankara, 1996.

Terkan, B. Gündem Belirleme Medya ve Siyasal Gündem Üzerine Bir Çalışma. 1. bask1, Tablet Kitabevi, Konya, 2005. 
Tutal, N. Küreselleşme Illetişim Kültürlerarasıllı. 1. baskı, Kırmızı Yayınları, Istanbul, 2006.

Türkmen, E. Kitlelerin Sosyal Ağlar Ile Aracılanmış Gündem Belirleme Gücü: Gezi Park1 Örneği. 1. Marmara Lisansüstü İletişim Öğrencileri Sempozyumu. “Medya Analizleri” Oturumu Bildiri Sunumu. 8-9 Mayıs 2014.

Türkoğlu, N. Toplumsal İletişim İletişim Bilimlerinden Kültürel Çalışmalara. 1. baskı. Babil Yayınları, İstanbul, 2004.

Yeğen, C. (2014). Medyanin Kamuoyu Oluşturma ve Gündem Belirleme Rolü Üzerine: Sarai Sierra Haberleriyle Oluşturulan Yapay Gündem. Dicle Üniversitesi Sosyal Bilimler Enstitüsü Dergisi (DÜSBED), 6(12): 21-46, 2014.

Yüksel, E. Medyanın Gündem Belirleme Gücü. 1. bask1, Çizgi Kitabevi Yayınları, Konya, 2001.

Yüksel, E. "Kamиoyu Oluşturma" ve "Gündem Belirleme" Kavramları Nerede Kesişmekte, Nerede Ayrılmaktadır? Anadolu Üniversitesi Sosyal Bilimler Dergisi, 7(1): 571-586, 2007. url1: https://digitalreport.wearesocial.com/ 



\title{
A STUDY ON THE RELATION BETWEEN CONSOLIDATION COEFFICIENT AND PLASTICITY INDEX OF FINE-GRADED SOILS
}

\author{
Assist. Prof. Dr. Kaveh DEHGHANIAN \\ İstanbul Aydın University \\ Engineering Faculty, Civil Engineering Department \\ kavehdehghanian@aydin.com \\ https:/orcid.org/0000-0002-6372-4984 \\ Emrah ÇALTILI \\ İstanbul Aydın University \\ Engineering Faculty, Civil Engineering Department \\ emrahcaltili@aydin.edu.tr \\ https://orcid.org/0000-0002-8411-3250
}

\begin{abstract}
Consolidation coefficient $\left(\mathrm{C}_{\mathrm{v}}\right)$ is one of the key parameters in calculation of soil settlement rate. This parameter can be determined using one-Dimensional consolidation test. Prediction of $\mathrm{C}_{\mathrm{v}}$ in fine-graded soils with different Liquid Limit (LL) and Plasticity Index (PI) is also substantial to have a better understanding of soil behavior. In the present study, two fine-graded soils encompassing a broad range of liquid (LL) and plastic limits (PL) are selected and conventional consolidation tests are conducted on these samples. The samples are tested using their natural water content. It was observed that increasing liquid limit and plasticity index decreases $\mathrm{C}_{\mathrm{v}}$.
\end{abstract}

Keywords: Consolidation Coefficient, Liquid Limit, Plastic Index, Consolidation test, Fine-Graded soils 


\section{INCE-DANELİ ZEMINLERIN KONSOLIDASYON KATSAYISI İLE PLASTISITE INNDEKSİ ARASINDAKI ILIŞKININI İNCELENMESI}

\section{ÖZ}

Oturma hesaplanmasında konsolidasyon katsayısı $\left(\mathrm{C}_{\mathrm{v}}\right)$ en önemli parametrelerden biridir. Bu parametre tek boyutlu konsolidasyon testi kullanılarak belirlenebilir. Farklı Likit Limitli (LL) ve Plastisite İndeksli (PI) ince-daneli zeminlerde $\mathrm{C}_{\mathrm{v}}$ 'nin tahmin edilmesi, toprak davranışının daha iyi anlaşılması için önemlidir. $\mathrm{Bu}$ çalışmada, geniş bir aralıkta Likit ve Plastik limitleri (PL) içeren iki iyiderecelenmiş zemin seçilmiş ve bu numuneler üzerinde geleneksel konsolidasyon testleri yapılmıştır. Numuneler doğal su içeriği kullanılarak test edilir. Artan Likit Limit ve Plastisite indeksi, $\mathrm{C}_{\mathrm{v}}$ değerini düşürür.

Anahtar Kelimeler: Konsolidasyon Katsaylsl, Likit Limit, Plastik İndeksi, Konsolidasyon Testi, Ince-Daneli Zeminler

\section{INTRODUCTION}

Settlement in clay soils, specially in soft soils, is a challenging issue. Construction of any structure on this type of soil can be expensive and time consuming. In order to overcome this problem, behavior study of such soils is vital and helps to implement a suitable soil improvement technique. The consolidation process is a mixture of two parameters: the permeability, which controls the rate of the expelling water out of the soil and consequently the rate of settlement at the desired time, and the compressibility, which controls the process of excess pore pressures and thus the duration of the consolidation. During the consolidation process of a saturated clay layer, compressibility and permeability are closely linked together. In the base form of Terzaghi theory in which a linear stress-strain relation and a constant permeability are assumed, the consolidation is controlled by the coefficient of consolidation $\left(\mathrm{C}_{\mathrm{v}}\right)$ (Leroueil, 1987). The coefficient of consolidation demonstrates 1-D consolidation of a clay subjected to a surcharge which is a function of hydraulic conductivity $(\mathrm{k})$, coefficient of compressibility $\left(\mathrm{m}_{\mathrm{v}}\right)$ and unit weight of water $\left(\gamma_{\mathrm{w}}\right)$. This factor can be expressed in the form of

$C_{v}=\frac{k}{\gamma_{w} m_{v}}$

The one-dimensional consolidation test was first suggested by Terzaghi. This test is performed in an oedometer (Das, 2009). Two main standard methods are proposed for evaluating coefficients of consolidation of clayey soils in soil mechanics and foundation engineering applications, namely the logarithm of time fitting (Casagrande method) and the square root of time fitting method 
(Taylor method). Both of these methods need the reading of compression dial gauges at specified intervals of time during the process of consolidation of a clayey specimen in the oedometer under an applied pressure (Taylor, 1948; Lambe and Whitman, 1969; Das, 2009). In the logarithm of time fitting method, $\mathrm{C}_{\mathrm{v}}$ is determined using readings from minimum 24 hours. In this method, $\mathrm{C}_{\mathrm{v}}$ is determined using formula (2) such as:

$C_{v}=\frac{0.197 H^{2}}{t_{50}}$

In which $t_{50}$ is the time required for $50 \%$ consolidation and $\mathrm{H}$ is the thickness of the soil layer. In the square root of time fitting method, readings of the dial gage are taken till the minimum $90 \%$ of the primary compression of the test specimen. In this method, $\mathrm{C}_{\mathrm{v}}$ is calculated using formula (3) as:

$C_{v}=\frac{0.848 H^{2}}{t_{90}}$

In this formula, which $\mathrm{t}_{90}$ is the time required for $90 \%$ consolidation and $\mathrm{H}$ is the thickness of the soil layer. The graphical description of both mentioned methods are shown in figure (1).

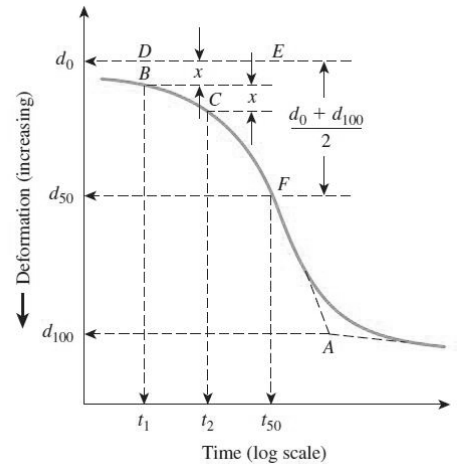

(a)

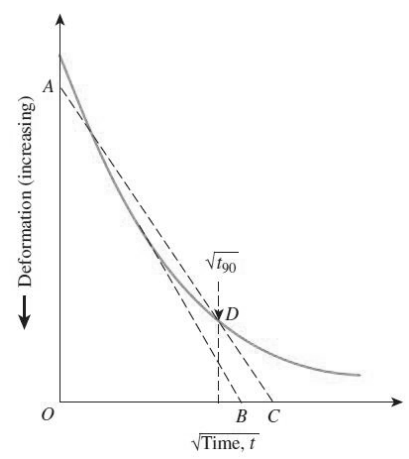

(b) 
Figure 1. (a) Logarithm-of-time method for determining coefficient of consolidation, (b) Square-root-of-time fitting method (Das, 2009).

Due to complexity of these methods, during past decades, researchers have investigated simpler and more reliable methods for the determination of coefficient of consolidation (Naylor and Doran, 1948; Sivaram and Swamee, 1977; Parkin, 1978,1981; Sridharan and Rao, 1981; Mikasa and Takada, 1986; Pandian et al., 1994; Singh, 2005). Although these alternative methods are not used in routine applications as observed from the recommendations of standards on consolidation tests (ASTM D 2435-04), because of the crucial importance of consolidation specially in foundation, prediction and interpretation of the settlement results under different surcharges is necessary. In literature, researchers have focused on the parameters affecting $\mathrm{C}_{\mathrm{v}}$ such as permeability, compressibility, Liquid Limit (LL) and Plastic Limit (PL) of soils. Atterberg limit tests are widely used to measure plasticity of soils (Bekker 1981). In these tests, liquid limit is a limit in which soil initiates to flow and plastic limit depicts the minimum water content to make the soil plastic (Whyte 1982, Haigh et al. 2013). These two parameters are used to calculate plastic index (PI). Due to complexity and long duration of consolidation test, several empirical relations are proposed between Atterberg limits and $\mathrm{C}_{\mathrm{v}}$ (Carrier 1985, Raju et al. 1995, Sridharan and Nagaraj 2004, Asma et al. 2011, Solanki 2011, Devi et al., 2015). Most of these relationships are not applicable for all soil types. Several correlations between these parameters and $\mathrm{C}_{\mathrm{v}}$ have been proposed (Carrier 1985, Raju et al. 1995, Sridharan \&Nagaraj 2004). Carrier (1985) related $\mathrm{C}_{\mathrm{v}}$ with activity (ACT), LL and PL. According to his findings, $\mathrm{C}_{\mathrm{v}}$ is inversely proportioned to Plastic Index (PI). Raju et al. (1995) related $\mathrm{C}_{\mathrm{v}}$ to the void ratio at the liquid limit and the in situ effective overburden pressure for normally consolidated clays. The proposed relationship has some deficiencies due to the limited range of LL and PL. Moreover, the considered consolidation parameter is only related to the LL. Lambe and Whitman (1979) proposed a range for $\mathrm{C}_{\mathrm{v}}$ as shown in Table 1.

Table 1: Typical values for Coefficient of Consolidation.

\begin{tabular}{|l|l|l|l|}
\hline Liquid Limit & $\begin{array}{l}\text { Lower Limit for } \\
\text { Recompression }\left(\mathrm{m}^{2} / \mathrm{s}\right)\end{array}$ & $\begin{array}{l}\text { Undisturbed Virgin } \\
\text { Compression }\left(\mathrm{m}^{2} / \mathrm{s}\right)\end{array}$ & $\begin{array}{l}\text { Upper Limit } \\
\text { Remolded }\left(\mathrm{m}^{2} / \mathrm{s}\right)\end{array}$ \\
\hline 30 & $3.5 \times 10^{-6}$ & $5 \times 10^{-7}$ & $1.2 \times 10^{-7}$ \\
\hline 60 & $3.5 \times 10^{-7}$ & $1 \times 10^{-7}$ & $3 \times 10^{-8}$ \\
\hline 100 & $4 \times 10^{-8}$ & $2 \times 10^{-8}$ & $1 \times 10^{-8}$ \\
\hline
\end{tabular}


Later Sridharan and Nagaraj (2004) proposed a relationship between $\mathrm{C}_{\mathrm{v}}$ and Shrinkage Index (SI). Terzaghi and Peck (1967) mentioned that consolidation coefficient does not change over a wide range of effective vertical consolidation pressure $\left(\sigma_{v}{ }_{v}\right)$. Robinson and Allam (1998) showed the relationship between $\mathrm{C}_{\mathrm{v}}$ $-\sigma^{*}$ and clay mineralogy. Sridharan and Nagaraj (2004) considered the relation of $\mathrm{C}_{\mathrm{v}}$ and $\sigma_{\mathrm{v}}{ }_{\mathrm{v}}$ for different plasticity and same LL which are only valid for remolded soils. Asmar et.al. (2011) correlated coefficient of consolidation with liquid limit for undisturbed silty clay of certain parts of Iraq.

In the absence of reliable correlations, inspection of variation of PI and $\mathrm{C}_{\mathrm{v}}$ seems inevitable to have a better understanding of the estimated results. In this paper, clay and silt samples from various locations with a broad range of PL and LL are selected and their correlation with $\mathrm{C}_{\mathrm{v}}$ is investigated.

\section{MATERIALS AND METHODOLOGY}

In this study, two types of fine- graded soil samples from different districts were used. For the first sample which is named as A1, fine-graded soil percentage was determined as 95.10 after sieve analysis. The second sample, named A2, had 95.52 percent fine-graded materials. The tests were performed according to Turkish Standards (TS-1900). The color of the A1 sample was greenish gray and A2 was red. Specific gravity tests of A1 was achieved as 2.77 and for A2 as 2.74. In the next step, standard Proctor test was performed according to TS 19001. A1 showed maximum dry density $\left(\gamma_{\text {dmax }}\right)$ of $1.570 \mathrm{gr} / \mathrm{cm}^{3}$ at optimum water content $\left(\omega_{\text {opt }}\right)$ of $18.8 \%$. A2 gained its maximum dry density of $1.620 \mathrm{gr} / \mathrm{cm}^{3}$ at $19.6 \%$ optimum water content. In order to classify the soil samples, Atterberg limit tests were done on these samples. In A1, LL was equal to 62.32 and PL is 29.33 , therefore plasticity index was calculated as 32.99 . For A2 sample, LL was obtained as 39.80 and PL as 27, hence PI was obtained as 12.80. Considering USCS classification system (Das B.M, 2009), A1 soil type was determined as high plastic clay $(\mathrm{CH})$ and $\mathrm{A} 2$ soil type as low plastic silt (ML). Figure 2 depicts the tests performed on soil samples. Afterwards, standard Proctor test was performed to find the optimum water content and maximum dry density. 


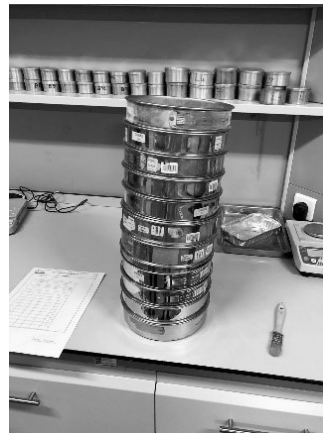

(a)

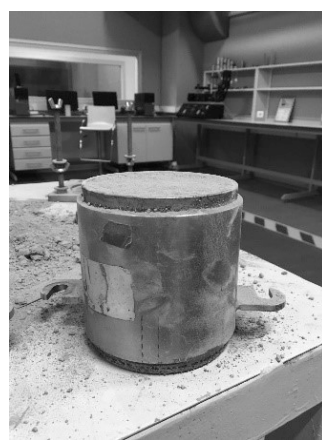

(c)

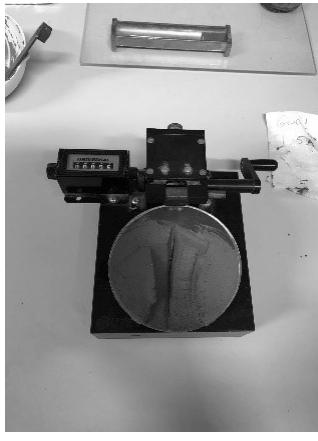

(b)

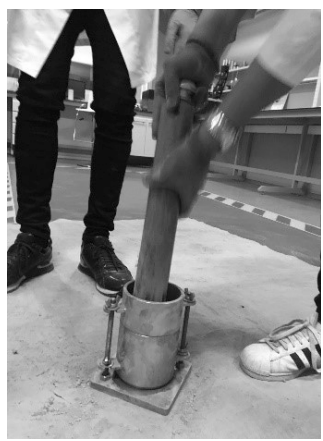

(d)

Figure 2. (a) Sieve analysis, (b) Atterberg test, (c) and (d) Proctor tests performed on soil samples.

Finally, one-dimensional consolidation tests were performed according to TS $1900-2$ standard. The test was conducted with 12,$5 ; 25 ; 50 ; 100 ; 200 ; 400 ; 800 ; 1600$ and $3200 \mathrm{kPa}$ applied stress. Readings were taken using a time interval of 0 , $6,18,30$ seconds and $1,2.25,4,6.25,9,16,25,36,49,64,81,100,121$ minutes and 4,9 and 24 hours. Then, each specimen was unloaded with the ratio of onefourth. Using Taylor's method (Shukla et al. 2009), coefficient of consolidation was calculated. The 1-D consolidation test is shown in Figure 3. 


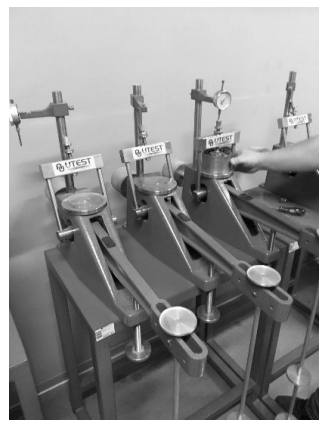

(a)

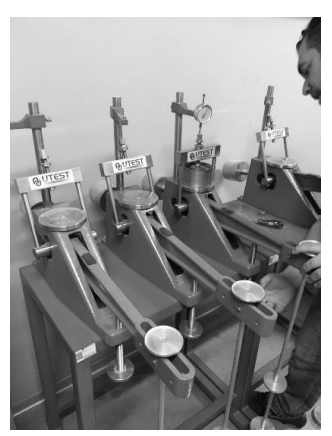

(b)

Figure 3. (a) and (b) Performed consolidation tests.

\section{RESULTS AND DISCUSSION}

Following the steps and tests described in materials and methods, $\mathrm{C}_{\mathrm{v}}$ was determined as $0.87 \times 10^{-3} \mathrm{~cm}^{2} / \mathrm{s}$ for sample A1 and $1.58 \times 10^{-3} \mathrm{~cm}^{2} / \mathrm{s}$ for sample A2. Both samples are classified as fine-graded soils. The specific gravity of both samples are close to each other. According to USCS classification system, LL with higher than 50 are classified as high plastic fine-graded soil and less than 50 is classified as low-plastic soil sample (Das, 2009). According to Ts-1500, both samples are in consistent with USCS and A1 and A2 are classified as high and low plastic soils respectively. Considering these classifications, A1 is classified as high-plastic clay (CH) and A2 is classified as low-plastic silt (ML). Different types of soils are selected deliberately to show the accuracy of the findings which are to correlate the plasticity and liquidity specifications of fine-graded soils with $\mathrm{C}_{\mathrm{v}}$. The summary of the achieved results is presented in Tables 2 and 3 . Considering the findings, it can be concluded that $\mathrm{C}_{\mathrm{v}}$ is not related to plastic limit. Since PL is approximately in the same range for both samples, it was observed that $\mathrm{C}_{\mathrm{v}}$ changes are almost close to PL. Moreover, as the optimum water content and maximum dry weight of two samples were close to each other, the relation between these parameters and consolidation coefficient was not observed.

Table 2: Soil properties of samples.

\begin{tabular}{|l|l|l|l|l|l|l|}
\hline Sample No & Fine-Graded Percentage & $\mathrm{G}_{\mathrm{s}}$ & LL & PL & PI & Soil Type \\
\hline A1 & 95.10 & 2.77 & 62.32 & 29.33 & 32,99 & $\mathrm{CH}$ \\
\hline A2 & 95.52 & 2.74 & 39.80 & 27 & 12.80 & ML \\
\hline
\end{tabular}


Table3: Consolidation parameters.

\begin{tabular}{|l|l|l|l|}
\hline Sample No & $\gamma_{\text {dmax }}\left(\mathrm{gr} / \mathrm{cm}^{3}\right)$ & $\boldsymbol{\omega}_{\text {opt }}$ & $\mathrm{C}_{\mathrm{V}}\left(\mathrm{cm}^{2} / \mathrm{s}\right)$ \\
\hline A1 & 1.570 & $18.8 \%$ & $0.87 \times 10^{-3}$ \\
\hline A2 & 1.620 & $19.6 \%$ & $1.58 \times 10^{-3}$ \\
\hline
\end{tabular}

\section{CONCLUSION}

In order to have a better understanding of $\mathrm{C}_{\mathrm{v}}$ variance, the properties of samples with different water content, specific gravity, liquid limit, plastic limit, sieve analysis and soil classification, fine graded percentage and consolidation coefficient were tested in this study. The tests were performed according to Turkish standards, TS1900-1 and TS1900-2. The classifications of soil materials were done according to Unified Soil Classification System (USCS), which is a prevalent method for soil classification. This classification enables us to have a better comparison between our finding and the literature. Moreover, it is consistent with TS-1900. Samples were determined as high plastic clay and low plastic silt, which is consistent with the aim of this study. In order to have a rigorous and comprehensive research, both types of fine-graded soil materials; silt and clay comprising vast particle diameters were utilized. A broad range of liquid limits represents the soil from low plasticity to high plasticity. Soil classification according to TS- 1900 varies insignificantly from USCS for fine graded soils. TS-1900 considers fine particles with the liquid limit between 35 and 50 as intermediate plastic particles and lower than 35 as low-plastic particles, while USCS categorizes fine particles with LL lower than 50 as low-plastic fine soils. In both standards, the liquid limit higher than 50 is considered as high-plastic soils. Our A1 sample is classified the same in both systems, while A2 sample is considered as intermediate plastic silt using Ts-1900. This difference does not affect our findings significantly, thus the unified system use was preferred. The samples with high fine-graded percentage was preferred in this study so that the impact of coarse-graded materials on behavior of consolidation coefficient was minimized. Obtained $\mathrm{C}_{\mathrm{v}}$ results in Tables 2 and 3 reveal that as plasticity increases, the consolidation coefficient decreases. This finding is applicable for both silt and clay soil types, which can be justified as the long required period of drainage in high plastic soils. Due to plasticity, these soils have a very slow drainage rate and consolidation settlement occurs very slowly. Moreover, it can be observed that $\mathrm{C}_{\mathrm{v}}$ has an inverse proportion with LL too, which can be justified in the same way. The water absorption capacity of soils with high LL is also high and these kind of soils are not willing to lose water rapidly. Due to low variance of optimum water content, the impact on this parameter on consolidation coefficient was not significant in this study. These findings are prominent and can lead to have a better understanding of fine-graded soil material behavior, especially for the calculation of consolidation settlements. 


\section{REFERENCES}

Asma Y. Al-Tae'e \& Abbas F. Al-Ameri. "Estimation of relation between coefficient of consolidation and liquid limit of Middle and South Iraqi soils", 17 (2): 433-440, 2011.

ASTM D2435 / D2435M - 11. Standard Test Methods for One-Dimensional Consolidation Properties of Soils Using Incremental Loading, ASTM International, United States.

Bekker, P.C.F. "Simple Clay Testing Methods". Ziegelindustrie International, 9 , Bau-Verlag, Wiesbaden, Germany, 494-503, 1981.

Carrier, W. D., III, "Consolidation parameters derived from index tests", Geotechnique, 35(2): 211-213, 1985.

Das, B.M. Principles of Geotechnical Engineering-SI Version, Cengage Learning, 2009.

Devi S.P, Devi K.R., Prasad DSV, Raju P.GVR. "Study on consolidation and correlation with index properties of different soils in Manipur valley", International Journal of Engineering Research and Development, 11(5): 57-63, 2015.

Haigh, S. K., Vandanege, P.J., and Bolton M.D. "The Plastic Limit of Clays", Geotechnique, 63(6): 435-440, 2013.

Lambe, T. W. and Whitman, R. V. Soil Mechanics, John Wiley and Sons, New York, 1979.

Leroueil, S. "Tenth Canadian geotechnical colloquium: recent developments in consolidation of natural clays." Canadian Geotechnical Journal, 25: 85-107, 1987.

Mikasa, M. and Takada, N. "Determination of coefficient of consolidation $\left(C_{v}\right)$ for large strain and variable $C_{v}$ values." Consolidation of Soils: Testing and Evaluation, ASTM STP 892, R.N. Yong and F.C. Townsend, Eds., American Society for Testing and Materials, Philadelphia, 526-547, 1986.

Naylor, A.H. and Doran, I.G. "Precise determination of primary consolidation." Proc. of the 2nd International Conference on Soil Mechanics and Foundation Engineering, Rotterdam, 1: 34-40, 1948.

Pandian, N.S., Sridharan, A. and Kumar, K.S. "Improved velocity method for the determination of coefficient of consolidation." Geotechnical Testing Journal, ASTM, 17(1): 113-118, 1994.

Parkin, A.K. "Coefficient of consolidation by the velocity method." Geotechnique, 28(4): 472-474, 1978. 
Parkin, A.K. "Consolidation analysis by velocity method." Proc., 10th International Conference on Soil Mechanics and Foundation Engineering, Stockholm, 1: 723-726, 1981.

Raju Narasimha, P. S. R., Pandian, N. S., and Nagaraj, T. S. "Analysis and Estimation of Coefficient of Consolidation", Geotechnical Testing Journal, 18(2): 252-258, 1995.

Robinson, R. G. and Allam, M. M., "Effect of Clay Mineralogy on Coefficient of Consolidation," Clays and Clay Minerals, 46(5): 596-600, 1998.

Shukla S.K, Sivakugan N, Das B.M. "Methods for determination of the coefficient of consolidation and field observations of time rate of settlement-an overview", International Journal of Geotechnical Engineering, 3(1): 89-108, 2009.

Singh, S.K. "Estimating consolidation coefficient and final settlement: triangular excess pore-water pressure." Journal of Geotechnical and Geoenvironmental Engineering, ASCE, 131(8): 1050-1055, 2005.

Sivaram, B. and Swamee, P.K. "A computational method for consolidation coefficient." Soils and Foundations, 17(2): 48-52, 1977.

Solanki C. H. "Quick settlement computation of shallow foundation using soil index and plasticity characteristics", Geotechnical conference, 1-5, 2011.

Sridharan, A., Nagaraj, H.B. "Coefficient of consolidation and its correlation with index properties of remolded soils", Geotechnical Testing Journal, 27 (5): 1-6, 2004.

Sridharan, A. and Rao, A. "Rectangular hyperbola fitting method for one dimensional consolidation." Geotechnical Testing Journal, ASTM, 4(4): 161168,1981 .

Taylor, D.W. Fundamentals of Soil Mechanics, John Wiley and Sons, New York, 1948 .

Terzaghi, K. and Peck, R. B. Soil Mechanics in Engineering Practice, John Wiley and Sons, New York, 1967.

Turkish Standard, TS 1900-1, Methods of testing soils for civil engineering purposes in the laboratory - Part 1: Determination of physical properties, Turkish Standard Institute, Ankara, March 2006.

Turkish Standard, TS 1900-2, Methods of testing soils for civil engineering purposes in the laboratory - Part 2: Determination of mechanical properties, Turkish Standard Institute, Ankara, March 2006.

Whyte, I. L, "Soil Plasticity and Strength- A new approach using extrusion", Ground Engineering, 15 (1): 16-24, 1982. 


\title{
HASILATIN TFRS 15 MÜŞTERI SÖZLEŞMELERINDEN HASILAT STANDARDI, BOBİ FRS BÖLÜM 5 VE VERGİ KANUNLARINA GÖRE KARŞILAŞTIRMALI INCELENMESİ
}

\author{
Doç. Dr. Yıldırım Ercan ÇALIŞ \\ Marmara Üniversitesi \\ ecalis@marmara.edu.tr \\ https://orcid.org/0000-0002-6783- 9164 \\ Burcu HIŞMAN \\ Marmara Üniversitesi İşletme Fakültesi \\ burcuhisman@hotmail.com \\ https://orcid.org/0000-0002-1461-6477
}

\begin{abstract}
ÖZ
Hasılat; mal ve hizmet satışı, faiz, temettü, komisyon gibi işletmenin olağan faaliyetleri sonucunda ortaya çıkan gelirlerinden oluşmaktadır. Hasılat kavramının uluslararası ve ulusal düzenlemelerde farklı şekillerde tanımlanması, hasılata ilişkin yapılacak işlemlerde bazı farklılıkların ortaya çıkmasına neden olmaktadır. Bu çalışmada, TFRS 15 Müşteri Sözleşmelerinden Hasılat Standardı ve BOBİ FRS Bölüm 5'de yer alan hasılata ilişkin düzenlemeler ile Vergi Usul Kanunu hükümleri karşılaştırarak, benzerlikler ve farklılıklar ortaya konulmaya çalışılmış olup, konu bir uygulama ile karşılaştırmalı şekilde incelenmiştir.
\end{abstract}

Anahtar Kelimeler: TFRS 15 Müşteri Sözleşmelerinden Hasılat, BOBI FRS Bölüm 5, Hasılat, Hasılatın Muhasebeleştirilmesi 


\title{
A COMPARATIVE REVENUE ANALYSIS ACCORDING TO THE REVENUE STANDARDS OF IFRS 15 CUSTOMER CONTRACTS, BOBI FRS 5 AND TAX LAWS
}

\begin{abstract}
Revenues consist of the earnings that emerge as a result of the ordinary operations of a company such as the sales of goods and services, interests, dividends, commissions, etc. The different definitions of revenue in international and national regulations causes some differences in transactions regarding revenues. In this study, the similarities and differences between the TFRS 15 Standard of Revenue from Contacts with Customers and Revenue Regulations in the BOBI FRS Chapter 5 were compared with the Turkish Tax Procedural Law; the similarities and differences were presented and the subject was examined comparatively with an application.
\end{abstract}

Keywords: TFRS 15 Revenue from Contracts with Costumer, BOBI FRS Chapter 5, Revenue, Revenue Recognition

\section{GİRIŞ}

Kâr, işletme performansının en önemli göstergelerinden biridir. Hasılat ise kârın önemli bir unsurunu oluşturmaktadır. Hasılatın doğru şekilde tespit edilmesi ve raporlanması işletme ile ilgilenen kişi ve kuruluşların işletmeyle ilgili doğru kararlar almalarına önemli derecede katkı sağlamaktadır. Hasılatın ölçümü, muhasebeleştirilmesi ve sunumuna ilişkin olarak ülkemizde TFRS 15, BOBİ FRS ve Vergi Usul Kanunu'nda farklı düzenlemeler yer almaktadır.

TFRS 15 Müş̧eri Sözleşmelerinden Hasılat Standard1 9 Eylül 2016 Tarihli ve 29826 sayll Resmi Gazetede yayımlanarak 01 Ocak 2018 tarihinden itibaren uygulanmak üzere yürürlüğe girmiştir. TFRS 15 Standardının amacı, müşteriyle yapılan bir sözleşmeden doğan hasılatın ve nakit akışlarının niteliği, tutarı, zamanlaması ve belirsizliğine yönelik faydalı bilgilerin finansal tablo kullanıcılarına raporlanmasında işletmenin uygulayacağı ilkeleri düzenlemek şeklinde belirtilmiştir (TFRS 15.1). TFRS 15 Müşteri Sözleşmelerinden Hasılat Standardının yürürlüğe girmesiyle TMS 11 İnşaat Sözleşmeleri, TMS 18 Hasılat, TFRS Yorum 13 Müșteri Sadakat Programları, TFRS Yorum 15 Gayrimenkul İnşaat Anlaşmaları, TFRS Yorum 18 Müşterilerden Varlık Transferleri ve TMS Yorum 31 Hasılat-Reklam Hizmetleri İçeren Takas İşlemleri standartlarının yerini almıştır (TFRS 15. Ek C10).

Büyük ve Orta Boy İşletmeler İçin Finansal Raporlama Standardı (BOBİ FRS) ise bağımsız denetime tabi olup Türkiye Finansal Raporlama Standartları'nı 
(TFRS) uygulamayan işletmelerin uygulayacakları finansal raporlama çerçevesi olup, Kamu Gözetim Kurumu tarafindan 29 Temmuz 2017 tarihinde 30138 sayılı Mükerrer Resmi Gazetede yayınlanmıştır. BOBİ FRS'nin amacı gerçeğe uygun, finansal bilgi ihtiyacına uygun ve karşılaştırılabilir finansal tablolar düzenlenmesini sağlamaktır.

Hasılat tutarının belirlenmesine ve raporlanmasına yönelik TFRS 15, BOBİ FRS ve vergi mevzuatımızda farklılıklar bulunmaktadır. Çalışmada, TFRS 15 Müşteri Sözleşmelerinden Hasılat Standardı ve BOBİ FRS Bölüm 5'de yer alan hasılata ilişkin düzenlemeler ile Vergi Usul Kanunu hükümleri karşılaştırarak, benzerlikler ve farkl11klar ortaya konulmaya çalışılmış olup, konu bir uygulama ile karşılaştırmalı şekilde incelenmiştir.

\section{LITERATÜR TARAMASI}

TMS 18 ve TMS 11 Standartlarının yürürlükten kalkması nedeniyle TFRS 15 ile ilgili yapılan çalışmalar incelenmiş olup, literatür taramasında TFRS 15 ve BOBİ FRS ile ilgili olarak yapılmış olan çalışmalar dahil edilmiştir.

Ciesielski ve Weirich (2015) çalışmalarında, TFRS 15 standardındaki beş aşamalı model açıklanarak, standardın özellikle telekomünikasyon gibi çok unsurlu sözleşmelerin olduğu sektörleri etkileyeceği üzerinde durulmuştur. Keskin ve Dinçer (2015) çalışmalarında, TFRS 15 Müşteri Sözleşmelerinden Hasılat Standardındaki beş aşamalı modelin temel özellikleri ve gelirin nasıl tahakkuk ettirileceği açıklanmıştır. Ayrıca TFRS 15 ile TMS 18 Standartları'nın temel farkları telekomünikasyon sektörüne ait bir örnekle ortaya konulmuştur. Yeaton (2015) çalışmasında, TFRS 15'in beş aşamalı modelini açıklayarak yeni standardın, hasılatın tanımlanması ve hasılat ile ilgili sorunların ele alınması için kapsamlı, sağlam bir muhasebe modeli sunduğunu belirtmiştir. Ayrıca standardın amacının endüstriden veya coğrafi bölgeden bağımsız olarak, hasılat tanıma konusunda tutarlı ilkeler sağlamak olduğunu ifade etmiştir. Calayoğlu ve Yılmaz (2016) yapılan çalışmada, TFRS 15'in beş aşamalı modeline göre yazılım sektörünün önemli gelir unsurları açıklanarak, standart kapsamında her bir gelir kaleminin hasılatı örnekler üzerinden tespit edilmiştir. Rutledge, Karim ve Kim (2016) çalışmalarında, TFRS 15 Standardının yürürlüğe girmesinin kazanç kalitesi, ertelenmiş vergiler, yönetim tazminatı ve sektörel özellikler üzerindeki etkileri incelenmiştir. Aktaş ve Varol (2017) çalışmalarında, TFRS 15 Müşteri Sözleşmelerinden Hasılat Standardının TMS 18 Hasılat Standardı ile karşılaştırılması yapılmıştır. Ayrıca çok unsurlu sözleşmeler ve sözleşme değişiklikleri TFRS 15 ve TMS 18 standart hükümleri çerçevesinde örnek olay üzerinden incelenmiştir. Ataman ve Cavlak (2017) tarafından yapılan çalışmada, TFRS 15 Müşteri Sözleşmelerinden Hasılat standardı çerçevesinde hasılatın 
tanımlanması, ölçülmesi ve muhasebeleştirilmesine yönelik düzenlemeler incelenmiştir. Ayrıca bu düzenlemeler kapsamında bir uygulamaya yer verilmiştir. Ataman ve Cavlak (2017) tarafindan yapılan çalışmada, BOBİ FRS ile Tam Set TMS/TFRS karşıllaştırması yapılmıştır. Yapılan değerlendirme de her iki düzenlemenin büyük ölçüde uyumlu olmasının yanı sıra aralarında bazı temel farklılıkların olduğu sonucuna varılmıştır. Gençoğlu Ümit Gücenme (2017) yapılan çalışmada, BOBİ FRS ile TMS/TFRS temel konularda karşılaştırma yapılarak benzerlikler ve farklılıklar ortaya konulmuştur. Mert ve Baş (2017) yapılan çalışmada, TMS 18 Hasılat standardına göre factoring işlemlerinin hasılat tutarının gerçeğe uygun değer ile muhasebeleştirilerek, vadeli işlemlerde ortaya çıkan faiz gelirinin tek düzen muhasebe sisteminde nasıl muhasebeleşeceği ve yeni uygulanacak olan UFRS 15 Müşteri Sözleşmelerinden Hasılat standardının olası etkisi incelenmiştir. Demirkol (2018) tarafından yapılan çalışmada, TFRS 15 Standardının beş aşamalı modeli üzerinde durularak konu örneklerle açıklanmaya çalışılmıştır. Doğan (2018) yapılan çalışmada, BOBİ FRS ile VUK/MSUGT düzenlemeleri arasindaki farklılıklar ve benzerlikler üzerinde durulmuştur. Gökçen, Öztürk ve Güleç (2018) yapılan çalışmada, BOBİ FRS ile TFRS setleri arasındaki farklılıklar açıklanarak, bu farklılıkların finansal raporları nasıl etkileyeceği üzerinde durulmuştur. Çalışmada örneklendirilen farklılıklar sonucunda BOBİ FRS kapsamında sunulan finansal raporların gerçeğe uygun nitelikte finansal bilgi sunamadığı vurgulanmaktadır. Kıllı ve Işık (2018) yapılan çalışmada, yıllara yaygın inşaat ve onarım işleri kapsamındaki müşterilerle yapılan inşa sözleşmeleri TFRS 15 Müşteri Sözleşmelerinden Hasılat, BOBİ FRS ve TMS 23 Borçlanma Maliyetleri Standardı hükümleri çerçevesinde örnek bir uygulama ile incelenmiştir. Saban, Gürkan ve Vargün (2019) yapılan çalışmada, TFRS 15 Müşteri Sözleşmelerinden Hasılat Standardının hasılatın zamanlaması konusunda ortaya koyduğu yaklaşımlar örnek olay üzerinden ve gayrimenkul sektörü açısından incelenmiştir. Sabuncu (2018) yapılan çalışmada, hasılatın ölçüm ve muhasebeleştirilme esasları Tekdüzen Muhasebe Sistemi ve BOBİ FRS açısından karşılaştırılarak incelenmiştir.

Bu çalışmada, TFRS 15 Müşteri Sözleşmelerinden Hasılat Standardı ve BOBİ FRS Bölüm 5'de yer alan hasılata ilişkin düzenlemeler ile Vergi Usul Kanunu hükümleri karşılaştırarak, benzerlikler ve farklılıklar ortaya konulmaya çalışılmıştır.

\section{TFRS 15 MÜŞTERİ SÖZLEŞMELERINDEN HASILATIN MUHASEBELEŞTIRILMESI, ÖLÇÜMÜ VE SUNUMU}

TFRS 15 kapsamında mal satışları, hizmet sunumları, inşaat sözleşmeleri, fikri mülkiyet haklarının tescili, parasal olmayan varlıkların takası gibi işlemler finansal tablolara yansıtılması gereken işlemler olarak sınıflandırılabilir (Şavlı, 2016: 25). 
Hasılat; satı̧s, faiz, temettü, komisyon gibi işletmenin olağan faaliyetleri sonucunda ortaya çıan gelirleridir. TFRS 15 Standardına göre hasılat, işletmenin olağan faaliyetleri esnasında ortaya çıkan geliri olarak tanımlanmaktadır (TFRS 15 EKA). Yeni bir hasılat tanıma modeli oluşturan TFRS 15 standardı, hasılatın belli bir zamanda $\mathrm{m} 1$ yoksa zaman içerisinde mi tanınacağına karar vermeye yardımcı olur. Ayrıca oluşturulan model belli konularda daha ayrıntılı rehberlik sağlamaktadır (Thornton, 2014 1). TFRS 15'de hasılatın muhasebeleştirme sürecini anlatan beş aşamalı model yer almaktadır. Bu model de:

- Müşteri ile yapılan sözleşmenin tanımlanması,

- Sözleşmedeki edim yükümlülüklerinin tanımlanması,

- İşlem bedelinin belirlenmesi,

- İşlem bedelinin sözleşmede belirlenen her bir edim yükümlülüklerine dağıtılması,

- Her bir edim yükümlülüğü yerine getirildiğinde veya getirildikçe hasılatın finansal tablolara alınması aşamaları yer almaktadır (Yeaton, 2015: 50-52). TFRS 15 'de hasılatın muhasebeleştirilme sürecini anlatan model aşağıda yer almaktadır.

\section{Müşteri ile Yapılan Sözleşmenin Tanımlanması}

Sözleşmenin Standart kapsamına alınabilmesi için:

(i) Sözleşmenin tarafları sözleşmeyi yazılı veya sözlü onaylamalıdır,

(ii) Sözleşmede, devredilecek mal veya hizmetlerle ilgili tarafların hakları tanımlanmalidır.

(iii) Devredilecek mal veya hizmetler için ödeme koşulları belirlenmelidir.

(iv) Sözleşme özü itibariyle ticari nitelikte olmalıdır.

(v) Devredilecek mal veya hizmetler karşılığında hak kazanılan bedelin tahsilatı muhtemel olmalidir (TFRS 15.9).

\section{Sözleşmedeki Edim Yükümlülüklerinin Tanımlanması}

Özellikle çoklu gelir unsuru taşıyan sözleşmelerde, başka bir ifadeyle tek bir satış sözleşmesinde birden fazla mal ve hizmetin satılması durumunda, işlem bedelinin sözleşme kapsamındaki farklı mal ve hizmetlere dağıtılması gerekmektedir (Şavlı, 2016: 55). Bu dağıtımın yapılabilmesi için her bir edim yükümlülüğünün belirlenmesi gerekir. Örneğin teknolojik ürünlerin satışını yapan bir işletmenin, bilgisayar yanında işletim sistemi yazılım programının da satışını yapması durumunda birden fazla edim yükümlülüğü söz konusudur.

\section{İşlem Bedelinin Belirlenmesi}

Bir edim yükümlülüğü yerine getirildiğinde (veya getirildikçe), işletme bu edim yükümlülüğüne tekabül eden işlem bedelini hasılat olarak finansal tablolara alır 
(TFRS 15.46). TFRS 15 İşlem bedelini, işletmenin üçüncü şahıslar adına tahsil edilen tutarlar hariç, taahhüt ettiği mal veya hizmetleri müşteriye devretmesi karşılığında hak etmeyi beklediği bedel olarak tanımlamaktadır (TFRS 15.47). Standarda göre işlem bedeline işletmenin üçüncü kişiler adına almak zorunda olduğu katma değer vergisi, özel tüketim vergisi vb. tutarlar dahil edilmez (Saban, Gürkan \& Vargün, 2019: 48).

\section{İşlem Bedelinin Edim Yükümlülüklerine Dağıtılması}

İşlem bedelinin dağıtımındaki amaç, işlem bedelinin her bir edim yükümlülügüne tahsis edilmesidir (TFRS 15.73). Sözleşmede, başlangıcında her bir edim yükümlülüğünün tek başına satış fiyatı belirlenir ve işlem bedeli bu tek başına satış fiyatlarına orantılı bir şekilde dağıttılır (TFRS 15.76). Örneğin bilgisayar ve işletim sistemi yazılım programının birlikte satı̧s yapılması halinde, birden fazla edim yükümlülüğünün olması nedeniyle işlem bedelinin edim yükümlülüklerine dağıtılması gerekmektedir. Bilgisayar ve işletim sistemi yazılım programının bağımsız satış fiyatlarının toplam bağımsız satış fiyatındaki ağırlık oranları bulunarak işlem bedeli edim yükümlülüklerine dağıtılır. İşlem bedelinin edim yükümlülüklerine dağıtımı Tablo 1'de gösterilmiştir.

Tablo 1: İşlem bedelinin edim yükümlülüklerine dağıtımı

\begin{tabular}{|l|c|c|c|c|}
\hline $\begin{array}{l}\text { Edim } \\
\text { Yükümlülükleri }\end{array}$ & $\begin{array}{l}\text { Bağımsız } \\
\text { Satış } \\
\text { Fiyatı TL }\end{array}$ & $\begin{array}{l}\text { Bağımsız Satış } \\
\text { Fiyatına Göre } \\
\text { Ağırıı Oranı \% }\end{array}$ & $\begin{array}{l}\text { Bilgisayar } \\
\text { (İsletim Sistemi } \\
\text { Hediyeli) TL }\end{array}$ & $\begin{array}{l}\text { Hasılat } \\
\text { TL }\end{array}$ \\
\hline Bilgisayar & 4.620 & 70 & 5.600 & 3.920 \\
\hline $\begin{array}{l}\text { İşletim Sis. } \\
\text { Yazılım Programı }\end{array}$ & 1.980 & 30 & 0 & 1.680 \\
\hline TOPLAM & 6.600 & 100 & 5.600 & 5.600 \\
\hline
\end{tabular}

\section{Edim Yükümlülüğü Yerine Getirildiğinde Hasılatın Finansal Tablolara} Alınması

İşletme, müşteri ile yapmış olduğu sözleşmede taahhüt ettiği mal ya da hizmeti müşterisine devrederek edim yükümlülüğünü yerine getirdiğinde veya getirdikçe hasılatı muhasebeleştirir (TFRS 15.31). Edim yükümlülüğü ya zamana yayılı olarak ya da belli bir anda yerine getirilir. İşletme, edim yükümlülügünü zamana yayılı olarak yerine getirmesi halinde, edimini yerine getirdiği tutarda hasılat olarak finansal tablolara yansitır(TFRS 15.32-35). 
Kolaylaştırıcı bir uygulama olarak standartta bir yıl veya bir yıldan daha kısa vadeli satışlarda önemli bir finansman bileşeninin etkisi için düzeltme yapmanın zorunlu olmadığı belirtilmiştir (TFRS 15.63). Uygulama kolaylığı hariç olmak üzere tüm vade farkları süreye bakılmaksızın hasılattan ayrıştırılarak faiz geliri olarak kayda alınır (TFRS 15.65).

\section{BOBİ FRS BÖLÜM 5 HASILATIN MUHASEBELEŞTİRILMESİ, ÖLÇÜMÜ VE SUNUMU BOBİ FRS (5.2.)}

Hasılatı, işletmenin olağan faaliyetleri esnasında ortaya çıkan geliri olarak tanımlamaktadır. Bölüm kapsamında mal satışları, hizmet sunumu, işletmenin yüklenici olduğu inşa sözleşmeleri, işletme varlıklarının başkaları tarafından kullanılmasından sağlanan faiz, isim hakkı ve kâr payı işlemleri yer almaktadır (BOBİ FRS 5.3).

BOBİ FRS'de hasılatın, ekonomik faydaların işletmeye girmesinin muhtemel olması ve söz konusu faydaların güvenilir biçimde ölçülebilmesi ile muhasebeleştirileceği belirtilmiştir. BOBİ FRS Bölüm 5'de mal satışına ilişkin hasılatın, kayda alınması için:

(i) Malların sahipliğinden kaynaklanan önemli risk ve getirilerin alıcıya devredilmesi,

(ii) Satılan mallar üzerinde bir kontrolün sürdürülmemesi,

(iii) Hasılat tutarının güvenilir biçimde ölçülebilmesi,

(iv) İşleme ilişkin ekonomik faydaların işletmece elde edilmesinin muhtemel olmas1,

(v) İşleme ilişkin maliyetlerin güvenilir biçimde ölçülebilmesi ölçütlerinin tümünün gerçekleşmesi gerekmektedir (BOBİ FRS 5.14).

Hizmet sunumuna ilişkin hasılatın kayda alınması için:

(i) Hasılat tutarının güvenilir biçimde ölçülebilmesi,

(ii) İşleme ilişkin ekonomik faydaların işletme tarafından elde edilmesinin muhtemel olmas1,

(iii) Raporlama dönemi sonu itibarıyla işlemin tamamlanma düzeyinin güvenilir biçimde ölçülebilmesi,

(iv) İşlem ilişkin maliyetlerin güvenilir biçimde ölçülebiliyor olması

unsurlarının tümünün gerçekleşmesi gerekmektedir (BOBİ FRS 5.19).

BOBİ FRS Bölüm 5'de inşa sözleşmesi; bir varlığın veya tasarım, teknoloji, fonksiyon, nihai amaç veya kullanım açısından birbiriyle yakından ilişkili ya da birbirine bağımlı bir grup varlığın yapımı için özel olarak düzenlenmiş bir sözleşme olarak tanımlanmaktadır (BOBİ FRS 5.22). 
Hasılat, taraflar arasında yapılan anlaşma kapsamında, satış iskontoları (kasa ve miktar iskontoları) da düşüldükten sonra, alınan veya alınması beklenen bedel esas alınarak ölçülür (BOBİ FRS 5.8).

Hasılat bedelinin, bir yıl veya daha kısa sürede tahsil edilmesinin öngörülmesi durumunda hasılat, vade farkı ayrıştırması yapılmaksızın tahsil edilen veya edilmesi beklenen bedel üzerinden ölçülür. Hasılat bedelinin bir yıldan daha uzun bir vadede tahsil edilmesi durumunda ise hasılat, vade fark1 etkin faiz yöntemine göre ayrıştırılarak ilgili mal veya hizmetin peşin bedeli üzerinden ölçülür. Vade farkı tutarı, etkin faiz yöntemine göre hesaplanarak faiz geliri olarak muhasebeleştirilir (BOBİ FRS 5.9).

\section{HASILATIN MSUGT'NE VE VUK'A GÖRE MUHASEBELEŞTÍRILMESI, ÖLÇÜMÜ VE SUNUMU}

MSUGT'ne göre hasılatın kaynakları mal satışı, hizmet sunumu ve inşaat sözleşmeleridir (Doğan, 2018: 120). VUK'a göre ise mal ve hizmet satışından elde edilen hasılat, faturanın kesilmesiyle tahakkuk etmekte ve muhasebeleştirilmektedir (Şen \& Özbirecikli, 2018: 467). Başka bir ifadeyle bir mal ve hizmet satış işlemine ilişkin hasılatın gerçekleşmesi için hasılat tutarının içerik ve tutar olarak kesinleşmesi yeterli koşuldur (Yıkılmaz, Deran \& Erduru, 2016: 145).

VUK'a göre hizmet ifa edildiğinde ve gelir içerik ve tutar olarak kesinleştiğinde muhasebeleştirilebilmektedir (Şen \& Özbirecikli, 2018: 467). Hizmet sunumuna ilişkin hasılat tutarı, tamamlanmış sözleşme yöntemine göre işin tamamlandığ 1 dönemde muhasebeleştirilmekte ve finansal tablolara yansitılmaktadır. İnşaat sözleşmelerinden doğan hasılat tutarı, işin bittiği yıl belirlenmekte ve hasılatın tamamı o yılın gelir ve gideri arasında gösterilmektedir (Yıkılmaz, Deran \& Erduru, 2016: 148). Vergi mevzuatına göre yıllara yaygın inşaat ve onarım işlerinde kesin kâr ya da zararın işin bittiği yılda belirlenmekte ve tamamı o yılın geliri sayılmaktadır (Akdoğan, 2015: 111).

Hasılatın ölçümü, MSUGT'da satış fiyatından satış iskontoları düşülerek yapılmaktadır (Doğan, 2018: 120). Vadeli satışlarda ise Tekdüzen Muhasebe Sisteminde vade ister bir yıla kadar, ister bir yıldan uzun olsun, vadeli bedel hasılata konu edilmektedir (Şen \& Özbirecikli, 2018: 467). MSUGT'ne göre vade farkı hasılattan ayrıştırılmadan muhasebeleştirilmektedir (Doğan, 2018: 120). 
VUK' da, alacakların mukayyet değerleriyle değerleneceği belirtilmiştir(VUK md. 281). Alacak senetleri üzerinde yazılı olan değerle kaydedilir. Ancak değerleme sırasında vadeye kadar geçecek günlerin faizi göz önünde bulundurularak peşin değerlerinin bulunması ve bu değer üzerinden değerlenmesi gerekmektedir (Sevilengül, 2016: 399).

VUK'a göre vadeli satışların muhasebeleştirilmesinde, vade farkının ayrıca gösterilmesi gerekmemektedir. Vade farkının dahil edilmesiyle düzenlenen satış faturaları, toplam bedel üzerinden satış hasılatı olarak değerlendirilmektedir. Dönem sonlarında işletmenin senetli alacakları bulunması durumunda, bu alacaklar için reeskont işlemi isteğe bağlı olarak yapılabilmektedir. Bu işlemin sonucunda işletme tahakkuk etmemiş faiz tutarı kadar bir gider raporlayarak kârı azaltmaktadır. Ancak VUK hükümlerine göre senetsiz alacaklara herhangi bir reeskont işlemi uygulanması mümkün değildir (Selvi, Yılmaz \& Sarığlu, 2007: 35). VUK'a göre vadesi gelmemiş olan senede bağlı alacaklar değerleme gününün kıymetine indirilebilir. Bu takdirde, senette faiz oranı açıklanmış ise bu oran, açıklanmamışsa Cumhuriyet Merkez Bankasının resmi iskonto haddi uygulanır (VUK md. 281). Senedin tasarruf değeriyle değerlenmesi VUK'un reeskont işlemi ile ilgili hükümlerine göre yapılır (Selvi, Yılmaz \& Sarığlu, 2007: 37).

\section{HASILATIN TFRS 15 MÜŞTERİ SÖZLEŞMELERINNDEN HASILAT, BOBİ FRS BÖLÜM 5 VE MSUGT/VUK KARŞILAŞTIRILMASI}

Çalışmanın bu bölümünde ulusal ve uluslararası düzenlemeler ile ilgili karşılaştırmalı bir tablo sunulmuştur. TFRS 15, BOBİ FRS ve MSUGT/VUK kapsamında yapılan karşılaştırma Tablo 2'de gösterilmiştir. 
Tablo 2: Hasılatın TFRS 15 müşteri sözleşmelerinden hasılat, BOBİ FRS Bölüm 5 ve MSUGT/VUK karşılaştırılması

\begin{tabular}{|c|c|c|c|c|}
\hline & $\begin{array}{l}\text { TFRS } 15 \text { Müşteri } \\
\text { Sözleşmelerinden } \\
\text { Hasılat }\end{array}$ & $\begin{array}{c}\text { BOBİ FRS Bölüm } 5 \\
\text { Hasılat }\end{array}$ & MSUGT/VUK & Farklılıklar \\
\hline \multirow{3}{*}{ 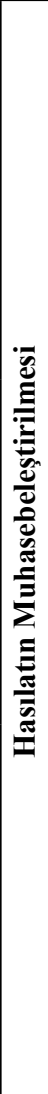 } & $\begin{array}{l}\text { İşletme, müşteri } \\
\text { ile yapmış olduğu } \\
\text { sözleşmede taahhüt ettiği } \\
\text { bir mal ya da hizmeti } \\
\text { müşterisine devrederek } \\
\text { edim yükümlülüğünü } \\
\text { yerine getirdiğinde } \\
\text { veya getirdikçe hasılatı } \\
\text { muhasebeleştirir (TFRS } \\
\text { 15.31). }\end{array}$ & $\begin{array}{l}\text { Hasılatın, ekonomik } \\
\text { faydaların işletmeye } \\
\text { girmesinin muhtemel } \\
\text { olması ve söz } \\
\text { konusu faydaların } \\
\text { güvenilir biçimde } \\
\text { ölçülebilmesi ile } \\
\text { muhasebeleştirileceği } \\
\text { belirtilmiştir (BOBİ } \\
\text { FRS 5.5). }\end{array}$ & $\begin{array}{l}\text { Mal ve hizmet } \\
\text { satışından elde edilen } \\
\text { hasılat, faturanın } \\
\text { kesilmesiyle } \\
\text { tahakkuk etmekte ve } \\
\text { muhasebeleştirilmektedir } \\
\text { (Şen, Özbirecikli, 2018: } \\
\text { 467). }\end{array}$ & $\begin{array}{l}\text { TFRS 15'de } \\
\text { hasılatın } \\
\text { tanımlanması, } \\
\text { finansal tablolara } \\
\text { alınmasına ilişkin } \\
\text { oluşturulan } 5 \\
\text { Aşamalı Model } \\
\text { BOBİ FRS, } \\
\text { MSUGT/VUK da } \\
\text { yer almamaktadır. }\end{array}$ \\
\hline & $\begin{array}{l}\text { Standarda göre işlem } \\
\text { bedeline işletmenin } \\
\text { üçüncü kişiler adına } \\
\text { almak zorunda olduğu } \\
\text { katma değer vergisi, } \\
\text { özel tüketim vergisi vb. } \\
\text { tutarlar dahil edilmez } \\
\text { (Saban vd., 2019: 48). }\end{array}$ & $\begin{array}{l}\text { BOBİ FRS'de hasılat } \\
\text { tutarına üçüncü } \\
\text { taraflar adına tahsil } \\
\text { edilen tutarlar dahil } \\
\text { edilmez. Örneğin } \\
\text { katma değer vergisi } \\
\text { hasılat olarak } \\
\text { muhasebeleştirilmez } \\
\text { (BOBİ FRS 5.10). }\end{array}$ & $\begin{array}{l}\text { Hasılat tutarına üçüncü } \\
\text { taraflar adına tahsil } \\
\text { edilen katma değer } \\
\text { vergisi vb. tutarlar dahil } \\
\text { edilmez. }\end{array}$ & $\begin{array}{l}\text { Fark } \\
\text { bulunmamaktadır. }\end{array}$ \\
\hline & $\begin{array}{l}\text { İşletmelerin gelecekteki } \\
\text { nakit akışlarında bir } \\
\text { değişikliğin olmaması, } \\
\text { üstlendikleri riskte bir } \\
\text { değişikliğin olmaması, } \\
\text { aynı özelliklere sahip } \\
\text { malların takası standardın } \\
\text { kapsamı dışında } \\
\text { bırakılmıştır (Şavlı, 2016: } \\
\text { 28-29). }\end{array}$ & $\begin{array}{l}\text { Mal veya hizmetlerin } \\
\text { benzer özelliklere } \\
\text { ve değere sahip mal } \\
\text { veya hizmetlerle } \\
\text { takas edilmesinde } \\
\text { hasılat ortaya çıkmaz } \\
\text { (BOBİ FRS 5.12). }\end{array}$ & & $\begin{array}{l}\text { TFRS } 15 \text { Standardı } \\
\text { BOBİ FRS ile } \\
\text { uyumluyken } \\
\text { MSUGT/VUK } \\
\text { da bir düzenleme } \\
\text { bulunmamaktadır. }\end{array}$ \\
\hline : & $\begin{array}{l}\text { İşlem bedeli esas } \\
\text { alınarak ölçülür. İşlem } \\
\text { bedeli, işletmenin } \\
\text { üçüncü şahıslar adına } \\
\text { tahsil ettiği tutarlar hariç, } \\
\text { taahhüt ettiği mal veya } \\
\text { hizmetleri müşsteriye } \\
\text { devretmesi karşıllığında } \\
\text { hak etmeyi beklediği } \\
\text { bedeldir. (TFRS 15.47). }\end{array}$ & $\begin{array}{l}\text { Hasılat, taraflar } \\
\text { arasında yapılan } \\
\text { anlaşma kapsamında, } \\
\text { satış iskontoları (kasa } \\
\text { ve miktar iskontoları) } \\
\text { da düşüldükten sonra, } \\
\text { alınan veya alınması } \\
\text { beklenen bedel esas } \\
\text { alınarak ölçülür } \\
\text { (BOBİ FRS 5.8). }\end{array}$ & $\begin{array}{l}\text { Hasılatın ölçümü, } \\
\text { MSUGT'da satış } \\
\text { fiyatından satış } \\
\text { iskontoları düşülerek } \\
\text { yapılmaktadır (Doğan, } \\
\text { 2018: 120). }\end{array}$ & $\begin{array}{l}\text { BOBİ FRS } \\
\text { ile MSUGT/ } \\
\text { VUK hükümleri } \\
\text { uyumludur. }\end{array}$ \\
\hline
\end{tabular}




\begin{tabular}{|c|c|c|c|c|}
\hline 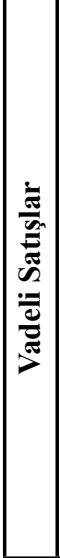 & $\begin{array}{l}\text { Kolaylaştırıcı bir } \\
\text { uygulama olarak bir yıl } \\
\text { veya bir yıldan daha kısa } \\
\text { vadeli satışlarda önemli } \\
\text { bir finansman bileşeninin } \\
\text { etkisi için düzeltme } \\
\text { yapılması zorunlu } \\
\text { değildir (TFRS 15.63). } \\
\text { Uygulama kolaylığ1 } \\
\text { hariç olmak üzere tüm } \\
\text { vade farkları süreye } \\
\text { bakılmaksızın hasılattan } \\
\text { ayrıştırılarak faiz geliri } \\
\text { olarak kayda alınır } \\
\text { (TFRS 15.65). }\end{array}$ & $\begin{array}{l}\text { Bir yıl veya bir yıldan } \\
\text { daha kısa vadeli } \\
\text { satışlarda vade farkı } \\
\text { ayrıştırılmamaktadır. } \\
\text { Vade süresi bir yıldan } \\
\text { uzun olan satışlarda } \\
\text { ise vade fark1, } \\
\text { hasılattan ayrıştırılıp } \\
\text { ve faiz geliri olarak } \\
\text { kaydedilir. Vade fark1 } \\
\text { etkin faiz yöntemine } \\
\text { göre hesaplanır } \\
\text { (BOBİ FRS 5.9). }\end{array}$ & $\begin{array}{l}\text { MSUGT'ne ve VUK'na } \\
\text { göre, vade farkları } \\
\text { ayrıştırılmamaktadır. } \\
\text { VUK'a göre dönem } \\
\text { sonlarında işletmenin } \\
\text { senetli alacakları } \\
\text { bulunması durumunda, } \\
\text { bu alacaklar için } \\
\text { reeskont işlemi } \\
\text { isteğe bağlı olarak } \\
\text { yapılabilmektedir } \\
\text { (Selvi, 2007: 35). }\end{array}$ & $\begin{array}{l}\text { Bir yıl ve bir yıldan } \\
\text { daha kısa vadeli } \\
\text { satılarda TFRS } \\
\text { 15, BOBİ FRS ile } \\
\text { MSUGT/VUK } \\
\text { düzenlemelerinde } \\
\text { vade farkı } \\
\text { ayrıştırılmazken, } \\
\text { bir yıldan uzun } \\
\text { vadeli satışlarda } \\
\text { sadece MSUGT/ } \\
\text { VUK hükümlerinde } \\
\text { vade farkı } \\
\text { ayrıştırılmamaktadır. }\end{array}$ \\
\hline 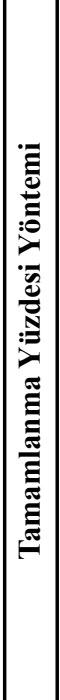 & $\begin{array}{l}\text { İşletme, edim } \\
\text { yükümlülüğünü zamana } \\
\text { yayıll olarak yerine } \\
\text { getirmesi halinde, } \\
\text { edimini yerine getirdiği } \\
\text { tutarda hasılat olarak } \\
\text { finansal tablolara yansıtır } \\
\text { (TFRS 15.32-35). }\end{array}$ & $\begin{array}{l}\text { Hizmet sunumuna } \\
\text { ilişkin bir } \\
\text { işlemin veya inşa } \\
\text { sözleşmesinin } \\
\text { sonucunun güvenilir } \\
\text { bir şekilde tahmin } \\
\text { edilebildiği } \\
\text { durumlarda, ilgili } \\
\text { hasılat tutarı } \\
\text { raporlama dönemi } \\
\text { sonu itibariyle söz } \\
\text { konusu işlemin } \\
\text { veya faaliyetin } \\
\text { tamamlanma düzeyi } \\
\text { dikkate alınarak, } \\
\text { hizmetin sunulduğu } \\
\text { dönemlerde finansal } \\
\text { tablolara yansit1lir } \\
\text { (BOBİ FRS 15.29). }\end{array}$ & $\begin{array}{l}\text { VUK'a göre hizmet } \\
\text { sunumuna ilişkin } \\
\text { hasılat tutarı, } \\
\text { tamamlanmış sözleşme } \\
\text { yöntemine göre işin } \\
\text { tamamlandığ1 dönemde } \\
\text { muhasebeleştirilmekte } \\
\text { ve finansal tablolara } \\
\text { yansıtılmaktadır. İnşaat } \\
\text { sözleşmelerinden doğan } \\
\text { hasılat tutarı, işin bittiği } \\
\text { yıl belirlenmekte ve } \\
\text { hasılatın tamamı o yılın } \\
\text { gelir ve gideri arasında } \\
\text { gösterilmektedir } \\
\text { (Y1kılmaz vd., 2016: } \\
\text { 148). }\end{array}$ & $\begin{array}{l}\text { Hasılat tutarı, } \\
\text { TFRS } 15 \text { ve } \\
\text { BOBİ FRS de işin } \\
\text { tamamlanma düzeyi } \\
\text { dikkate alınarak } \\
\text { muhasebeleştirilirken, } \\
\text { MSUGT/VUK da } \\
\text { hasılatın tamamı } \\
\text { işin bittiği dönemde } \\
\text { muhasebeleştirilir. }\end{array}$ \\
\hline
\end{tabular}




\begin{tabular}{|c|c|c|c|c|}
\hline $\mid \begin{array}{l}E \\
\text { 音 } \\
\text { 足 }\end{array}$ & $\begin{array}{l}\text { Standartta hasılatın } \\
\text { finansal tablolarda } \\
\text { sunumuyla ilgili aşağıdaki } \\
\text { unsurlar açıklanmıştır: } \\
\text { • Taraflardan biri } \\
\text { sözleşmeyi yerine } \\
\text { getirdiğinde, sözleşme } \\
\text { bir sözleşme varlığı ya da } \\
\text { sözleşme yükümlülüğ̈̈ } \\
\text { olarak finansal durum } \\
\text { tablosunda gösterilir } \\
\text { (TFRS 15.105). } \\
\text { • Müşteriyle yapılan } \\
\text { sözleşmeden doğan bir } \\
\text { alacağın ilk kez finansal } \\
\text { tablolara alınması } \\
\text { sırasında, alacağın } \\
\text { TFRS 9 Finansal Araçlar } \\
\text { standardı uyarınca, tespit } \\
\text { edilen değeri ile hasılat } \\
\text { olarak finansal tablolara } \\
\text { yansıtıllan tutar arasındaki } \\
\text { fark, finansal tablolarda } \\
\text { değer düşüklüğü zararı } \\
\text { olarak gösterilir (TFRS } \\
\text { 15.108). } \\
\bullet \text { İşletme, finansal } \\
\text { tablolarda "sözleşme } \\
\text { varlığı” ve "sözleşme } \\
\text { yükümlülügü" terimlerini } \\
\text { kullanmak yerine } \\
\text { alternatif bir ifade } \\
\text { kullanırsa, finansal tablo } \\
\text { kullanıcılarına alternatif } \\
\text { terimler kullanımı ile } \\
\text { ilgili yeterli bilgi verilir } \\
\text { (TFRS 15.109). }\end{array}$ & $\begin{array}{l}\text { BOBİ FRS } \\
\text { Bölüm } 5 \text { Hasılat } \\
\text { kapsamında hasılatın } \\
\text { finansal tablolarda } \\
\text { sunumuna ilişkin } \\
\text { ayrıca bir hüküm } \\
\text { bulunmamaktadır. }\end{array}$ & $\begin{array}{l}\text { MSUGT/VUK } \\
\text { hükümlerinde hasılatın } \\
\text { finansal tablolarda } \\
\text { sunumuna ilişkin } \\
\text { ayrıca bir hüküm } \\
\text { bulunmamaktadır. }\end{array}$ & $\begin{array}{l}\text { Hasılatın finansal } \\
\text { tablolarda } \\
\text { sunumuyla } \\
\text { ilgili unsurlar } \\
\text { sadece TFRS } \\
15 \text { Standardında } \\
\text { açıklanmıştır. }\end{array}$ \\
\hline
\end{tabular}




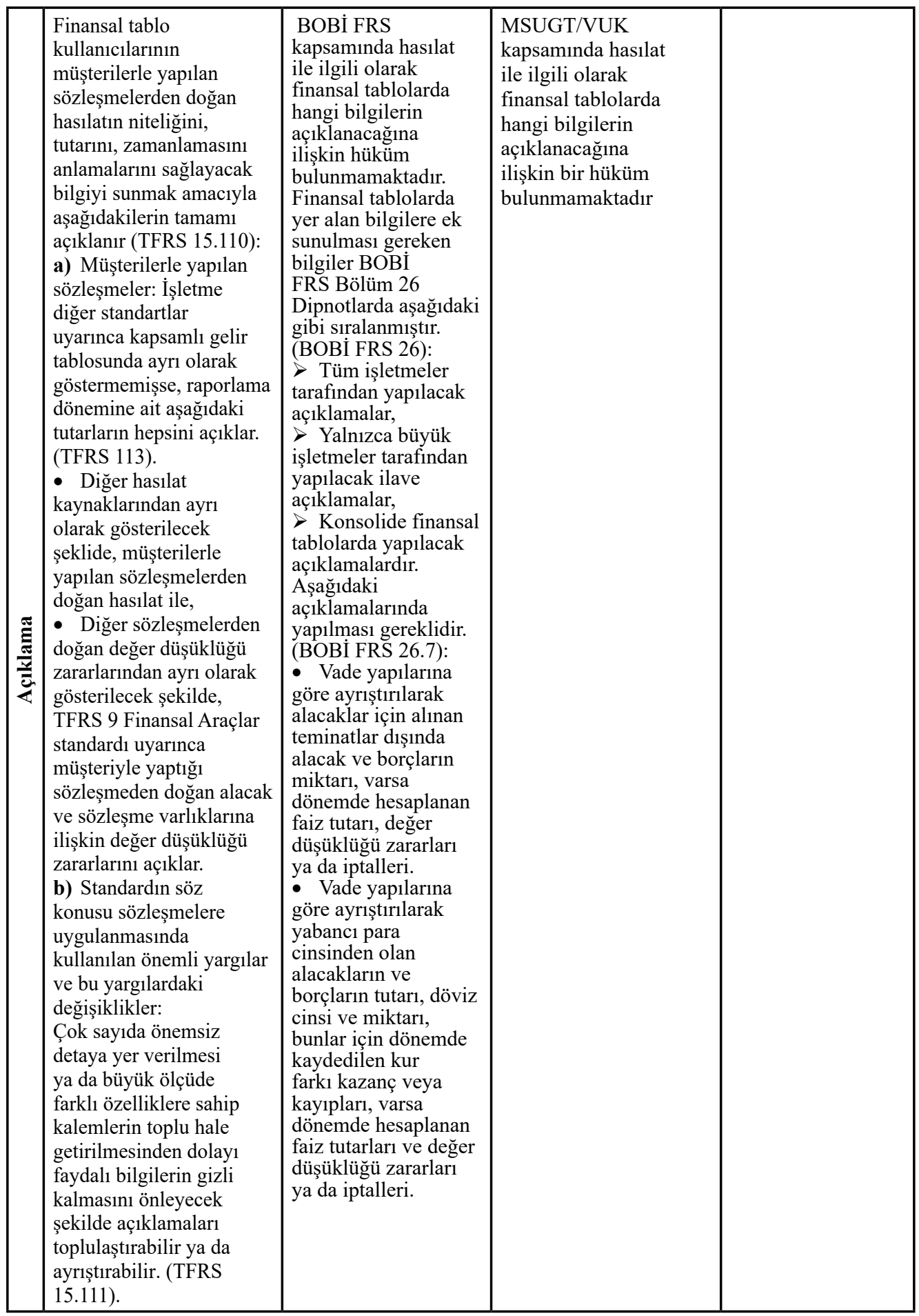




\section{UYGULAMA ÖRNEKLERİ}

\section{Uygulama 1}

X İşletmesi, 1 Ocak 201A tarihinde peşin satış fiyatı 20.000 TL olan ticari malı 2 yıl vadeli olarak $22.050 \mathrm{TL}+\% 18 \mathrm{KDV}$ 'ye satmıştır. Etkin faiz yöntemine göre hesaplanmış yıllık faiz oranı $\% 5$ 'tir.

\section{BOBİ FRS ve TFRS 15 standardına göre satış kaydının yapılması:}

1. Y1l Faizi: 20.000 TL $x 0,05=1.000 \mathrm{TL}$

2. Y11 Faizi: $21.000 \mathrm{TL} \times 0,05=1.050 \mathrm{TL}$

Toplam Vade Fark1: 2.050 TL

\begin{tabular}{|c|c|c|}
\hline $\begin{array}{l}\text { 220 ALICILAR } \\
\text { 600 YURT İÇİ SATIŞLAR } \\
\text { 3XX ERTELENMIŞ GELİRLER } \\
\text { 4XX ERTELENMIŞ GELİRLER } \\
\text { 391 HESAPLANAN KDV } \\
\text { Mal satış kaydı }\end{array}$ & 26.019 & $\begin{array}{c}20.000 \\
1.000 \\
1.050 \\
3.969\end{array}$ \\
\hline $\begin{array}{l}\text { 3XX ERTELENMISS GELIRLER } \\
\quad 642 \text { FAİ GELIRLERİ } \\
\text { Ertelenmiş gelirlerin faiz gelirlerine aktarılması }\end{array}$ & 1.000 & 1.000 \\
\hline $\begin{array}{l}\text { 4XX ERTELENMIŞ GELİRLER } \\
\text { 3XX ERTELENMIŞ GELİRLER } \\
\text { Ertelenmiş gelirlerin kısa vadeli yükümlülüklere aktarılması }\end{array}$ & 1.050 & 1.050 \\
\hline $\begin{array}{l}\text { 3XX ERTELENMISS GELIRLER } \\
\quad \text { 642 FAİ GELIRLERİ } \\
\text { Ertelenmiș gelirlerin faiz gelirlerine aktarılması }\end{array}$ & 1.050 & 1.050 \\
\hline
\end{tabular}

\section{VUK'a göre satış kaydının yapılması:}

\begin{tabular}{|l|c|c|}
\hline$\ldots \ldots \ldots \ldots \ldots \ldots \ldots \ldots \ldots$ & 26.019 & \\
120 ALICILAR & & 22.050 \\
600 YURT İÇİ SATIŞLAR & & 3.969 \\
391 HESAPLANAN KDV & & \\
Mal satış kaydı & & \\
\hline
\end{tabular}


31 Aralık 201A tarihine ait TFRS 15, BOBİ FRS ve VUK kapsamında oluşturulan gelir tablosuna ilişkin bilgilerin karşılaştırılması aşağıdaki gibidir.

\begin{tabular}{|l|c|c|c|}
\hline Gelir Tablosu & TFRS 15 & BOBİ FRS & VUK \\
\hline Hasılat (Satış Geliri) & 20.000 & 20.000 & 22.050 \\
\hline Faiz Geliri & 1.000 & 1.000 & ----- \\
\hline Kar & $\mathbf{2 1 . 0 0 0}$ & $\mathbf{2 1 . 0 0 0}$ & $\mathbf{2 2 . 0 5 0}$ \\
\hline
\end{tabular}

Satış hasılatı, işletmenin sattığı mal ya da hizmetin bedelini oluşturmaktadır; ancak vade farkı özünde işletmelerin müşterilerine açtı̆̆ 1 bir kredidir. Kredi karşıllğında elde edilen tutar ise satış hasılatı değil, faiz geliridir (Özyürek, 2012: 139). Vade farkının ortaya çıkmasına sebep olan zaman aralığının birden fazla hesap dönemine yayılması durumunda gelecek hesap dönemi, henüz finansal raporlamaya konu teşkil etmediği için bu döneme ait faiz geliri henüz tahakkuk etmediği için ertelenmesi söz konusudur. Bu nedenle ertelenmiş faiz geliri olarak adlandırılır (Ünkaya \& Dabbağoğlu, 2016: 124). TFRS 15 ve BOBİ FRS'ye göre vade farkının hasılattan ayrıştırılıp faiz geliri hesabına yansıtılması muhasebenin temel kavramlarından özün önceliği kavramına uygundur.

TFRS 15 ve BOBİ FRS'ye göre 600 Yurt İçi Satışlar hesabına sadece peşin tutar kaydedilmektedir. Vade farkı henüz tahakkuk etmediği için ertelenmiş faiz geliri hesabına kaydedilip dönem sonunda ise faiz geliri hesabına aktarılmaktadır. VUK hükümlerine göre ise senetsiz alacaklarda vade farkının ayrıştırılmasının yapılmayıp, vade farkının satış hasılatı içerisinde gösterilmesi ilgili döneme ait kârın olduğundan fazla ve yanlış raporlanmasına sebep olmaktadır. Dönemsellik kavramı gereğince elde edilen gelirin ve katlanılan giderin ne kadarının hangi döneme ait olduğunun ayrıştırılması gerekmektedir. VUK'na göre vade farkı (ayrıştırılıp ilgili dönemde gösterilmemesi) ayrıştırmasının yapılmaması muhasebenin temel kavramlarından dönemsellik kavramına aykırı olup, vade farkının faiz geliri hesabında gösterilmemesi de özün önceliği kavramına aykırıdır.

TFRS 15, BOBİ FRS Bölüm 5 ile ülkemiz vergi mevzuatı uygulaması farklılık gösterebilmektedir. Hasılatın tahakkuk ettirilmesinden kaynaklanan dönem farklılıkları, vergilerin ne zaman ve ne kadar ödenmesi gerektiğini etkilemektedir (Özyürek, 2012: 138).

\section{Uygulama 2}

ABC İşletmesi hastane ek bina yapımı için 15 Aralık 2017 tarihinde müşterisi ile sözleşme imzalamış olup bina yapımına 15 Ocak 2018 tarihinde başlanacaktır. Ek binanın 3 yıl içerisinde tamamlanması öngörülmektedir ve sözleşme tutarı 2.200.000 TL olarak belirlenmiştir. Binanın Ocak 2021 tarihine kadar teslim 
edilmesi gerekmektedir. İşletme, ek bina maliyetini 1.800.000 TL olarak tahmin etmektedir.

- İlk yıla ilişkin (31.12.2018) 540.000 TL maliyet gerçekleşmiştir.

- İkinci yılda müşteri işletme, hastane odalarından birine kurşun plaka (radyasyon yalıtımı) ve havalandırma sisteminin yapılmasını istemiştir. Yapılacak işin maliyeti 100.000 TL olup müşteri işletme tarafindan kabul edilmiştir. İkinci yılın sonunda inşaatın 1.900.000 TL'ye mal olacağ 1 tahmin edilmiştir. Bunun üzerine müşteri işletme ile görüşülmüş ve sözleşme bedeli 2.150.000 TL'ye çıkarılması kararlaştırılmıştır.

\begin{tabular}{|l|c|c|c|}
\hline & $\begin{array}{l}\text { Cari Yılda } \\
\text { Kaydedilen (TL) }\end{array}$ & $\begin{array}{l}\text { Geçmiş Yıllarda } \\
\text { Kaydedilen (TL) }\end{array}$ & $\begin{array}{l}\text { Kaydedilen } \\
\text { Toplam } \\
\text { Tutar (TL) }\end{array}$ \\
\hline 1.Yıl & & & \\
Gelir (2.000.000 x 0,30) & 600.000 & -------- & 600.000 \\
Maliyet (540.000/1800.000) & 540.000 & ------- & 540.000 \\
Kâr & $\mathbf{6 0 . 0 0 0}$ & ----- & $\mathbf{6 0 . 0 0 0}$ \\
\hline 2. Yıl & & & \\
Gelir (2.150.000 x 0,70) & 905.000 & 600.000 & 1.505 .000 \\
Maliyet (1900.000 x 0,70) & 790.000 & 540.000 & 1.330 .000 \\
Kâr & $\mathbf{1 1 5 . 0 0 0}$ & $\mathbf{6 0 . 0 0 0}$ & $\mathbf{2 1 0 . 0 0 0}$ \\
\hline 3. Yıl & & & \\
Gelir(2.150.000 x \%100) & 645.000 & 1.505 .000 & 2.150 .000 \\
Maliyet (1900.000 x \%100) & 570.000 & 1.330 .000 & 1.900 .000 \\
Kâr & $\mathbf{7 5 . 0 0 0}$ & $\mathbf{2 1 0 . 0 0 0}$ & $\mathbf{2 5 0 . 0 0 0}$ \\
\hline
\end{tabular}

BOBİ FRS Bölüm 5 ve TFRS 15 standardına göre 2018 yılı sonu itibariyle brüt satış hasılatın hesaplanması ve muhasebe kayıtları aşağıdaki gibidir:

Dönem maliyetinin toplam inşaat maliyeti içindeki oranına göre,

Tamamlanma Yüzdesi = İlgili tarihe kadar gerçekleşen maliyetler / Tahmini toplam maliyetler

$$
0,30=540.000 / 1800.000
$$

Hasılat Tutar $=$ Toplam Hasılat $\mathrm{x}$ Tamamlanma Yüzdesi

$$
=2.000 .000 \times 0.30=600.000 \mathrm{TL}
$$

2018 Yı1ı Brüt Satış Karı $=600.000-540.000=60.000$ TL 


\begin{tabular}{|c|c|c|}
\hline $\begin{array}{l}622 \text { SATILAN HIZMET MALIYETİ } \\
\text { 170 YILLARA YAYGIN İNŞAAT VE } \\
\text { ONARIM MALIYETİ } \\
\text { Maliyet kayd } 1\end{array}$ & 540.000 & 540.000 \\
\hline $\begin{array}{l}350 \text { YILLARA YAY. İNŞ. HAKEDİŞLERİ } \\
600 \text { YURTİÇI SATIŞLAR } \\
\text { Hakediş bedellerinin gelir tablosu hesabına aktarılması }\end{array}$ & 600.000 & 600.000 \\
\hline $\begin{array}{l}600 \text { YURTİÇI SATIŞLAR } \\
690 \text { DÖNEM KÂRI/ZARARI } \\
\text { Gelirlerin kâr zarar hesabına aktarımı }\end{array}$ & 600.000 & 600.000 \\
\hline $\begin{array}{l}690 \text { DÖNEM KÂRI /ZARARI } \\
622 \text { SATILAN HİMET MALIYETI } \\
\text { Giderlerin kâr zarar hesabına aktarımı }\end{array}$ & 540.000 & 540.000 \\
\hline $\begin{array}{l}690 \text { DÖNEM KÂRI/ZARARI } \\
692 \text { DÖNEM NET KÂR/ZARARI } \\
\text { Dönem kârının gelir tablosu hesabında gösterilmesi }\end{array}$ & 60.000 & 60.000 \\
\hline
\end{tabular}

BOBİ FRS Bölüm 5 ve TFRS 15 standardına göre 2019 yılı sonu itibariyle brüt satış hasılatın hesaplanması ve muhasebe kayıtları aşağıdaki gibidir:

Tamamlanma Yüzdesi = İlgili tarihe kadar gerçekleşen maliyetler/Tahmini toplam maliyetler $=1.330 .000 / 1.900 .000=0,70$

2019 y1l maliyet tutar $=1.330 .000-540.000=790.000 \mathrm{TL}$

Hasılat Tutarı $=$ Toplam hasılat $\mathrm{x}$ Tamamlanma yüzdesi

$$
=2.150 .000 \times 0.70=1.505 .000 \mathrm{TL}
$$

2019 y1l has1lat tutarı $=1.505 .000-600.000=905.000$

2019 Y11ı Brüt Satış Kârı $=905.000-790.000=115.000$ TL 


\begin{tabular}{|c|c|c|}
\hline 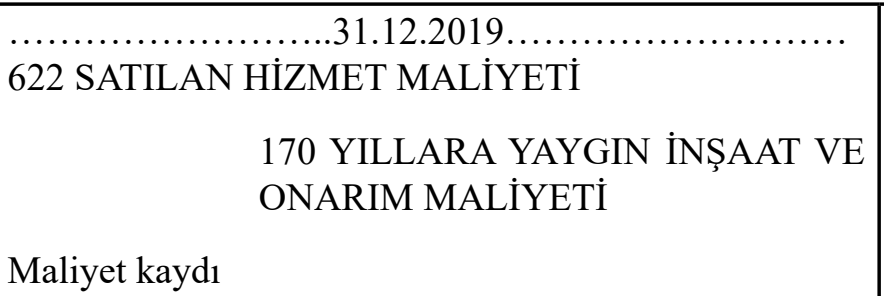 & 790.000 & 790.000 \\
\hline $\begin{array}{l}\text { 350 YILLARA YAY. İNŞ. HAKEDIŞ̧LRİ } \\
6600 \text { YURTİÇI SATIŞLAR } \\
\text { Hakediş bedellerinin gelir tablosu hesabına aktarılması }\end{array}$ & 905.000 & 905.000 \\
\hline $\begin{array}{l}600 \text { YURTIÇİ SATIŞLAR } \\
\qquad 690 \text { DÖNEM KÂRI/ZARARI } \\
\text { Gelirlerin kâr zarar hesabına aktarımı }\end{array}$ & 905.000 & 905.000 \\
\hline $\begin{array}{l}690 \text { DÖNEM KâRI /ZARARI } \\
622 \text { SATILAN HİMET MALIYETI } \\
\text { Giderlerin kâr zarar hesabına aktarımı }\end{array}$ & 790.000 & 790.000 \\
\hline $\begin{array}{l}\text { 690 DÖNEM KARI/ZARARI } \\
692 \text { DÖNEM NET KÂR/ZARARI } \\
\text { Dönem kârının gelir tablosu hesabında gösterilmesi }\end{array}$ & 115.000 & 115.000 \\
\hline
\end{tabular}

VUK'a göre hasılatın hesaplanması ve muhasebe kayıtları aşağıdaki gibidir:

\begin{tabular}{|c|c|c|}
\hline $\begin{array}{l}\text {..622 SATILAN HIZMET MALIYETI } \\
\text { VE ONARIM MALIYETI }\end{array}$ & 1.900 .000 & 1.900 .000 \\
\hline Maliyet kayd 1 & & \\
\hline $\begin{array}{l}350 \text { YILLARA YAY. İNŞ. HAKEDİŞLERİ } \\
600 \text { YURTİÇİ SATIŞLAR }\end{array}$ & 2.150 .000 & 2.150 .000 \\
\hline Hakediş bedellerinin gelir tablosu hesabına aktarılması & & \\
\hline
\end{tabular}




\begin{tabular}{|c|c|c|}
\hline $\begin{array}{c}\text { 600 YURTİÇI SATIŞLAR } \\
\text { 690 DÖNEM KÂRI/ZARARI }\end{array}$ & 2.150 .000 & \\
Gelirlerin kâr zarar hesabına aktarımı & & 2.150 .000 \\
\hline 690 DÖNEM KÂRI /ZARARI & & \\
622 SATILAN HİZMET & 1.900 .000 & \\
MALIYETİ & & 1.900 .000 \\
Giderlerin kâr zarar hesabına aktarımı & & \\
\hline
\end{tabular}

Dönem kârının gelir tablosu hesabında gösterilmesi

Yıllar itibariyle kârın TFRS 15, BOBİ FRS ve VUK kapsamında karşılaştırılması aşağıda yer almaktadır.

\begin{tabular}{|c|c|c|c|}
\hline Yıl & TFRS 15 & BOBİ FRS & VUK \\
\hline 2018 & 60.000 & 60.000 & ----- \\
\hline 2019 & 115.000 & 115.000 & ----- \\
\hline 2020 & 75.000 & 75.000 & 250.000 \\
\hline Toplam & $\mathbf{2 5 0 . 0 0 0}$ & $\mathbf{2 5 0 . 0 0 0}$ & $\mathbf{2 5 0 . 0 0 0}$ \\
\hline
\end{tabular}

TFRS 15 ve BOBİ FRS'de hasılat, işin tamamlanma düzeyine ya da edim yükümlülüğünün ilerlemesi dikkate alınarak muhasebeleştirilirken, VUK'a göre ise işlem, işin bittiği yılda kayda alınmaktadır. 2018 yılında TFRS 15 ve BOBİ FRS'na göre işin tamamlanma yüzdesi yöntemine göre hesaplanan kâr 60.000 TL olarak finansal tablolara yansitılmaktadır. VUK'a göre ise 2018 y1lında inşaat tamamlanmadığ için söz konusu inşaata yönelik herhangi bir kâr/zarar hesaplaması yapılmayacak ve finansal tablolara yansitılmayacaktır. Her bir düzenlemede 250.000 TL kâr elde edilmiş olsa da kârın yıllara dağılımı farklılık göstermektedir. TFRS 15 ve BOBİ FRS'de 2018 yılında kâr 60.000 TL olarak 2019 yılında ise 115.000 TL olarak finansal tablolarda yer almaktadır. VUK' da ise kârın tamamı 2020 yılına ait olarak gösterilmiştir. VUK'nun uygulanması durumunda, satış hasılatı tutarının yanlış tutarlarda finansal tablolara yansıtılmasına neden olmaktadır. Ayrıca bu durum, muhasebenin temel kavramlarından dönemsellik kavramına aykırıdır. Dönemsellik kavramının dikkate alındığı TFRS 15 ve BOBİ FRS işletme ilgililerine daha gerçekçi ve daha faydalı bilgiler sunmaktadır. 


\section{SONUÇ}

Uygulamalarla yapılan incelemede TFRS 15, BOBİ FRS Bölüm 5 ve VUK hükümleri arasında farkl1lıklara neden olan iki temel husus olduğu görülmüştür. Bunlardan ilki, vadeli satışlarda vade farkının ayrıştırılması ve raporlanması açısından farklı1ıklar bulunmaktadır. Hasılat bedelinin, bir yıl veya daha kısa sürede tahsil edilmesi durumunda, BOBİ FRS Bölüm 5 ve VUK hükümlerine göre vade farkı ayrıştırması yapılmazken, TFRS 15 standardında ise zorunlu tutulmamıştır. Ancak hasılat bedelinin bir yıldan daha uzun bir sürede tahsil edilmesi durumunda ise BOBİ FRS Bölüm 5 ve TFRS 15 standartlarına göre hasılat, işlemdeki vade farkı ayrıştırılmaktadır. Peşin satış fiyatı ile vadeli satış fiyatı arasındaki finansman unsuru olan vade farkı, hasılattan ayrı olarak kapsamlı gelir tablosunda "Esas Faaliyet Alacaklarına İlişkin Vade Farkı Gelirleri ve Esas Faaliyetlerle İlgili Kur Farkı Kazançları" hesabında kayda alınmaktadır. VUK hükümlerine göre ise senetsiz alacaklarda süreye bakılmaksızın vade farkı ayrıştırması yapılmamaktadır. Vade farkının ayrıştııılmayıp, hasılat tutarı içerisinde kayda alınması, ilgili döneme ait kârın olduğundan fazla ve yanlış raporlanmasına sebep olmaktadır. Ayrıca vade farkı ayrıştırmasının yapılmaması gelecek yıla ait olan faiz gelirinin ilgili dönemin finansal tablolarında gösterilmemesine neden olmaktadır. Muhasebenin temel kavramlarından biri olan dönemsellik kavramı; hasılatın, kârın aynı döneme ait maliyetlerle, zararla karşılaştırılarak muhasebeleştirilmesini ifade etmektedir. Dönemsellik kavramı gereğince elde edilen gelirin ve aynı dönemde katlanılan giderin ne kadarının hangi döneme ait olduğunun ayrıştııılması gerekmektedir. Vade farkının ilgili dönemin finansal tablolarında gösterilmemesi dönemsellik kavramına aykırıdır. Ayrıca finansman unsuru olan vade farkının ilgili hesapta gösterilmemesi muhasebenin temel kavramlarından özün önceliği kavramına da aykırıdır.

İkinci önemli farklılık ise BOBİ FRS Bölüm 5 ve TFRS 15 Standartlarında hizmet sunumu ya da inşa sözleşmesine ilişkin işlem, işin tamamlanma düzeyine ya da edim yükümlülüğünün ilerlemesi dikkate alınarak muhasebeleştirilir. Böylelikle ilgili hasılat tutarı raporlama dönemi sonu itibariyle söz konusu işlem ya da faaliyetin tamamlanma düzeyi dikkate alınarak kar ya da zarara yansitılır. VUK'a göre ise işlem, işin bittiği yılda kayda alınmaktadır. VUK'nun uygulanması durumunda, hasılat tutarının yanlış tutarlarda finansal tablolara yansıtılması söz konusu olup, muhasebenin temel kavramlarından dönemsellik kavramına aykırıdır.

TFRS 15 müşteriyle yapılan sözleşmeye dayalı bir standart olup, BOBİ FRS'ye göre daha ayrıntılı bir standarttır. Özellikle çoklu gelir unsuruna sahip işletmeler için önemlidir. Tek bir işlem adı altında yapılan birden fazla mal ve hizmet 
satışının her biri için edim yükümlülükleri tanımlanmakta ve işlem bedelleri belirlenmektedir. İşlem bedeli her bir edim yükümlülüklerine dağıtılmaktadır. Finansal tabloların doğruluğu, anlaşılabilir ve karşılaştırılabilir olması açısından önemlidir.

Hasılatın TFRS 15 ve BOBİ FRS kapsamında muhasebeleştirilmesi işletmeyle ilgilenen kişi ve kuruluşlara daha doğru ve güvenilir bilgi verilmesini sağlamaktadır.

\section{KAYNAKÇA}

Akdoğan, N. Maliyet Muhasebesi Uygulamaları. Gazi Kitabevi, Ankara, 2015.

Aktaş, R., Varol, I.D. Yeni Hasılat Standardı UFRS 15'e Göre Hasılatın Muhasebeleştirilmesi: Çok Unsurlu Sözleşmeler ve Sözleşme Değişiklikleri. Muhasebe ve Finansman Dergisi, (73): 28-50, 2017.

Ataman, B., Cavlak, H. TFRS 15 Müşteri Sözleşmelerinden Hasılat: Temel Illkelerin Incelenmesi ve Bir Uygulama. Marmara Üniversitesi İktisadi ve İdari Bilimler Dergisi, 39(2): 403-430, 2017.

Ataman, B., Cavlak, H. Büyük ve Orta Boy Işsletmeler için Finansal Raporlama Standard (BOBI FRS) ile Tam Set Türkiye Muhasebe ve Türkiye Finansal Raporlama Standartlarının (TMS/TFRS) Karşılaştırılması. Finans Ekonomi ve Sosyal Araştırmalar Dergisi, 2(3): 153-168, 2017.

Calayoğlu, İ., Yılmaz, R. TFRS-15'e Göre Yazılım Sektöründeki Sözleşmelerin Hasilatınin Hesaplanmast ve Taninmast. PESA International Journal of Social Studies, 2(2): 18-42, 2016.

Ciesielski, J.T., Weirich, T. R. Revenue Recognition: How It Will Impact Three Key Sectors. The Journal of Corporate Accounting \& Finance, 26(3): 31-39. doi:10.1002/jcaf.22037, 2015.

Demirkol, Ö.F. TFRS 15 Müşteri Sözleşmelerinden Hasılat Standardl: 5 Aşamalı Model. AVRASYA Uluslararası Araştırmalar Dergisi, 6(15): 415-434, 2018.

Doğan, A. Büyük ve Orta Boy İşletmeler İçin Finansal Raporlama Standardı ile VUK/MSUGT Karşılaş̧tırması. Muhasebe ve Finansman Dergisi, (80): 115-132, 2018.

Gençoğlu, Ü.G. Temel Konularda BOBI FRS ve TMS/TFRS Karşılaştırması. Muhasebe ve Finansman Dergisi, (76): 1-23, 2017. 
Gökçen, G., Öztürk, E., Güleç, Ö. F. BOBİ FRS ve TFRS'nin Finansal Raporlara Etkileri Açsından Karşılaştırılması. Finans Ekonomi ve Sosyal Araştırmalar Dergisi, 3(2): 437-457, 2018.

Keskin, A.İ., Dinçer, B. UFRS 15-Müşteri Sözleşmelerinden Elde Edilen Hasılat Standardinin Incelenmesi ve Telekomünikasyon Sektörüne İlişkin Bir Uygulama. Maliye ve Finans Yazıları, 1(103), 219-246, 2015.

Kılll, M., Işılk, Y. Yıllara Yaygın İnşaat ve Onarım İşlerinin TFRS 15 Müşteri Sözleşmelerinden Hasılat Standardı ve BOBI FRS Kapsaminda İncelenmesi. Anemon Muş Alparslan Üniversitesi Sosyal Bilimler Dergisi, 6(6): 1093-1104, 2018 .

Mert, H., Ece, B. TMS 18 Hasılat ve UFRS 15 Müssteri Sözleşmelerinden Hasılat Standartlarının Faktoring İşletmeleri Açısından Değerlendirilmesi. Muhasebe ve Denetime Bakış Dergisi, 17(52): 35-56, 2017.

Özyürek, H. TMS 18'e Göre Hasılatın Muhasebeleştirilmesi. Yönetim ve Organizasyon Bilimleri Dergisi, 4(1): 131-141, 2012.

Rutledge, R.W., Karim, K.E., Kim, T. The FASB's and IASB's New Revenue Recognition Standard: What Will Be the Effects on Earnings Quality, Defferred Taxes, Management Compensation, and on Indwtry-Specific Reporting?. The Journal of Corporate Accounting \& Finance, 27(6): 43-48, 2016. doi:10.1002/ jcaf.22188.

Saban, M., Gürkan, S., Vargün, H. TFRS 15 Müşteri Sözleşmelerinden Hasılat Standardl: Inşaat Sözleşmeleri Üzerine Bir Uygulama. Muhasebe ve Vergi Uygulamalart Dergisi, 12(1): 43-64, 2019.

Sabuncu, B. Büyük ve Orta Boy Işletmeler için Finansal Raporlama Standardı ve TekdüzenMuhasebeSistemiAçısındanHasılatınÖlçümveMuhasebeleş̧irilmesinin Incelenmesi. Muhasebe ve Bilim Dünyası Dergisi, 20(4): 738-760, 2018.

Selvi, Y., Yılmaz, F., Sarıoğlu, K. Kredili Satışların Muhasebeleştirilmesi ve Raporlanmasının UFRS ve VUK Açısından Karşılaştırılması. Mali Çözüm Dergisi, ISMMMO Yayın Organı, (80): 25-42, 2007.

Sevilengül, O. Genel Muhasebe. Gazi Kitabevi, Ankara, 2016.

Şavlı, T. UFRS 15 Kapsamında Açıklama ve Örneklerle Hasılatın Raporlanması, ISSMMMO Yayinları, Istanbul, 2016.

Şen, I. K., Özbirecikli, M. BOBİ FRS'nin Muhasebe Uygulamalarına Getirdiği Değişiklikler: BOBI FRS, TMS/TFRS, ve Mevcut Muhasebe Sistemi Çerçevesinde Bir Inceleme. Muhasebe ve Vergi Uygulamaları Dergisi, 462-484, 2018. 
Thornton, G. IFRS News Special Edition on Revenue. http://www.gtrus.com/doc/ public/gti/gti_ifrs_news_15.pdf, 2014.

Ünkaya, G., Dabbağoğlu, K. Yerel Finansal Raporlama Çerçevesi Taslağında Önerilen Satış Geliri ve Ticari Alacak Muhasebesi Üzerine Bir Eleştiri. Marmara Üniversitesi Öneri Dergisi, 12(4): 121-136, 2016.

Yeaton, K. A New World of Revenue Recognition: Revenue from Contracts with Customers. The CPA Journal; New York, 85(7): 50-54, 2015.

Yıkılmaz, S., Deran, A., Erdudu, I. Hasılat Yaratan İslemlerin Muhasebeleştirilme Illkelerinin Türk Vergi Mevzuatı ve Türkiye Muhasebe Standartları Kapsamında Incelenmesi: Muhasebe Meslek Mensupları Üzerine Bir Araştırma. Ömer Halisdemir Üniversitesi IIBF Dergisi, 9(4): 143-164, 2016.

KGK. TFRS 15 Müşteri Sözleşmelerinden Hasılat, TMS/TFRS Tam Seti, http:// www.kgk.gov.tr (Erişim tarihi: 06 Ocak 2019).

KGK. Bölüm 5 Hasılat, BOBİ FRS, http://www.kgk.gov.tr (Erişim tarihi: 06 Ocak 2019). 



\title{
YÜKSEKÖĞRETIMDE SOSYAL SORUMLULUK PROJELERİ; ÖĞRETMEN GÖRÜŞLERI ÜZERİNE BİR ARAŞTIRMA
}

\author{
Dr. Öğr. Üyesi Hicran Özlem ILGIN \\ Çanakkale Onsekiz Mart Üniversitesi, Türkiye \\ hicranilgin@comu.edu.tr \\ Orcid: 0000-0002-0549-0710
}

\section{ÖZ}

Bu çalışma, Namık Kemal Üniversitesi Marmara Ereğlisi Meslek Yüksekokulu öğrencileri tarafından 2015-2016 akademik yılı bahar döneminde kurulan ve koordinatörlüğü tarafımdan gerçekleştirilen MEMYO Sosyal Dayanışma ve Yardımlaşma Kulübünün yardım çalışmaları sonucunda ulaştığı okulların öğretmenlerinin yapılan çalışmalara ilişkin düşüncelerini kayıt altına almaktadır. Kulüp 2015-2016 akademik yılı bahar döneminde kurulmuş olan ve 2019 yılında halen faaliyet gösteren, Türkiye' de ihtiyaç sahibi öğrencilerin bulunduğu okullara yardım malzemesi toplayarak gönderen özgün bir sosyal sorumluluk projesi örneği olarak çalışmalarına devam etmektedir. Kulübün 3 yıllık süre zarfında 150 okul ve 4.000'in üzerinde öğrenciye yardım gönderdiği kayıt altındadır. Araştırmanın amacı, yükseköğretim öğrencilerinin sosyal sorumluluk bilincinin geliştirilmesi amacıyla kurulan kulübün çalışmaları sonucunda yardım gönderilen okullardaki öğretmenlerin projeye bakış açıları, öğrencilerinin ve velilerinin projeye ilişkin tepkileri ve bu çalışmaların yardım gönderilen öğrencilerde gelecekte olası etkilerinin öğretmen görüşlerine dayalı olarak değerlendirilmesidir. Bu bağlamda daha önce yardım gönderilen okullardan 10 öğretmen gönüllülük esasıyla seçilerek araştırma örneklemine alınmıştır. Öğretmenlerin farklı şehirlerde görev yapıyor olması nedeniyle her biri ile çevrimiçi görüşmeler gerçekleştirilerek hazırlanan sorular her bir öğretmene uygulanmıştır. Görüşme sonuçları frekans tabloları ile nicel bir biçimde sunulurken, öğretmenlerin söylemleri de aynı zamanda tabloların alt kısımlarında nitel olarak değerlendirilmiştir. Buna göre MEMYO Sosyal Dayanışma ve Yardımlaşma Kulübü çalışmalarının yardım gönderilen okul öğrencileri ve ilişkili çevrelerinde sosyal sorumluluk farkındalığı ve milli birlik bilinci gelişimi noktasında olumlu yönde role sahip olduğu görülmektedir.

Anahtar Kelimeler: Sosyal Sorumluluk, Yükseköğretim, Öğrenci Kulüpleri, Öğretmen Görüşleri

Geliş Tarihi: 23.05.2019, Kabul Tarihi: 15.08.2019, DOI NO: 10.17932/IAU.IAUD.m.13091352.2019.4/44.379-398 Araştırma Makalesi-Bu makale Turnitin programıla kontrol edilmiştir.

Copyright (C) Istanbul Aydin Üniversitesi 


\title{
SOCIAL RESPONSIBILITY PROJECTS IN HIGHER EDUCATION: A REASEARCH ON THEACHERS VIEWS
}

\begin{abstract}
Current study records the thoughts of the teachers of the contacted schools within the scope of the aid activities of MEMYO Social Solidarity and Assistance Club which was established by the students of Namı Kemal University, Marmaraereğlisi Vocational School during the academic year of 2015-2016. Continuing its activities today in 2019 , the Club presents a unique example of social responsibility project by collecting aid-materials and delivering them to the schools where there are students in need. It is officially recorded that the club has reached over 4,000 students in 150 schools in a 3-year period. The aim of the study is to evaluate the teachers' opinions about the project and the possible impacts of the students and their parents on the project based on the opinions of the teachers. In this context, 10 teachers from previous schools were selected on a voluntary basis. Since the teachers were working in different cities, online interviews were conducted with each individual. While the interview results are presented in a quantitative manner with frequency tables, the teachers' discourses are also evaluated qualitatively in the lower part of the tables. As a result, it is seen that the activities of MEMYO Social Solidarity and Assistance Club has a positive role in the awareness of social responsibility and development of national unity among the school students and related circles.
\end{abstract}

Keywords: Social Responsibility, Higher Education, Student's Clubs, Teachers Views

\section{GİRIŞ}

Dünyadaki ivme ile birlikte Türkiye'de de sosyal sorumluluk çalışmaları artmaktadır. Halkla ilişkilerin çift yönlü simetrik modeli ile çağdaş halkla ilişkiler anlayışııın toplumsal sorumluluk üzerine kurulu olmasının hedeflendiği günümüzde, sosyal sorumluluk projeleri tüm kurum ve kuruluşlarca değerlendirilmektedir. Hedef kitlelerin sempatisini ve anlayışını kazanmak amacıyla gerçekleştirilen bu çalışmaların aynı zamanda etkinlikleri incelendiğinde kalite sorunlarıyla karşılaşıldığı da görülmektedir. Yapılan bu çalışmalar, toplumsal sosyal sorumluluk farkındalı̆̆ının artmasında azımsanmayacak bir niteliğe sahiptir. Diğer yandan özellikle kurumların uyguladığı sosyal sorumluluk faaliyetlerine ilişkin sahada projelerin kapsadığı çevrelerin bu bağlamdaki değerlendirmeleri de ayrı bir çalışma alanı oluşturmaktadır. 
Yükseköğretim kurumlarındakiöğrencilerin mesleki eğitimlerine ilişkin akademik gelişimler elde ederken aynı zamanda toplumsal sosyal sorumluluk bilincini de elde etmeleri, en az akademik gelişim kadar önem taşımaktadır. Bu bağlamda bu çalışmada Marmara Ereğlisi Meslek Yüksekokulu öğrencileriyle uygulanan ve sürekliliği dördüncü yılına girmesiyle gerçekleşen Sosyal Dayanışma ve Yardımlaşma Kulübü ve kulübün yardım gönderdiği okullardaki öğretmenlerin görüşleri kayıt altına alınmaktadır. Sürdürülebilir bir sosyal sorumluluk kavramı için eğitim yaşamları boyunca öğrencileri projeler ile desteklemek ve bu projelerin yansımalarını diğer bir eğitim kanadı olan ilk, orta ve lise eğitmenlerinden almayı amaçlayan bu çalışmanın diğer yükseköğretim kurumlarına örnek teşkil etmesi amaçlanmaktadır.

\section{SOSYAL SORUMLULUK VE ÜNIVERSITELERDE SOSYAL SORUMLULUK}

İşletmenin kendi çıkarları dışında toplumun varlığını kabul etmesi, temel görevleri dışında toplumsal sorunlarla da ilgilenmesi, atacağı adımların doğuracağı sonuçları önceden düşünmesi, sorumlu davranışın temelini oluşturmaktadır. Halkla ilişkilerin temel görevlerinden birinsin kurum imajını yükseltmek olduğu düşünülürse, sosyal sorumluluk ve halkla ilişkiler arasındaki ilişki netleşecektir (Peltekoğlu 2012: 133). Sosyal sorumluluk kavramı, işletme faaliyetlerinin toplumun refahını dikkate alarak yürütülmesi ilkesi üzerine kurulmuştur. Başka bir ifadeyle sosyal sorumluluk, işletmelerin kâr elde etme yükümlülüklerinin yan sıra toplumdaki kişi ve kurumlara karşı da yükümlü ve cevap verme zorunluluğu olarak da ifade edilebilir (Sabuncuoğlu 2001: 73).Türkiye'de sosyal sorumluluk kavramı tarihine bakıldığında, kurumların sosyal sorumluluk uygulamalarına Osmanlı Devleti döneminde de rastlanmaktadır. Ahilik Teşkilatı, Lonca Teşkilat ve Vakıfların faaliyetleri bu kavram kapsamında ele alınabilir. Vakıf geleneğinin günümüzde de sürdüğü görülmektedir. Kurumsal sosyal sorumluluk kavramının gelişmeye ve kabul görmeye başlamasından önceki dönemlerde de var oldukları görülen geniş ölçekli kurumlara ait vakıflar, bu anlayışın devamı niteliğindedir. 1969'da kurulan Vehbi Koç Vakfı, 1974'te kurulan Hacı Ömer Sabancı Vakfı, 1978 'te kurulan Dr. Nejat F. Eczacıbaşı Vakfı, Türkiye'de sayılan ilk sosyal sorumluluk kuruluşlarındandır. Günümüzde ise bu vakıflar kurumsal sosyal sorumluluk uygulamalarının bir parçası ya da devamı olarak görülmektedir. Türkiye'de kurumların sosyal sorumluluk uygulamalarına 2000'li yıllardan sonra etkin ve yaygin bir biçimde yer verdiklerini görülmektedir (http://www. sosyalsorumluluk.org/kurumsal-sosyal-sorumlulugun-turkiyede-gelisimi/). Temelde Anadolu toplumunda yardımlaşmayı bir yaşam biçimi halinde olduğunu görmek çok da güç değildir. Diğer yandan Türkiye'de kurumsal sosyal sorumluluk faaliyetlerinin daha çok sivil toplum kuruluşu ve özel sektör arasındaki sponsorluk ve hayırseverlik etkinlikleri olarak algılanmakta olduğu 
görülmektedir. Bu çerçevede sosyal sorumluluğun halkla ilişkiler ve pazarlama ile karıştırıldığı söylenebilir (Göcenoğlu vd 2005: 72-79).

Sosyal sorumluluk bilincinin yerleşmesi ve gelişmesi için toplumsal desteğe ve eğitime ihtiyaç vardır (Hotamışlı vd 2010: 298). Eğitim örgütleri belirli alanlarda öğrencilere bilgi ve beceri kazandırmasının yanında, sosyal sorumluluğun gerekleri olan çalışma, işbirliği yapma, paylaşmaya açık olma ve ihtiyacı olanlara yardım etme gibi davranışları da öğrencilere kazandırmalıdır (Töremen 2011: 276). Manchester Üniversitesi'nin sosyal sorumluluk tanımında; "Sosyal sorumluluk ögretim, araştırma ve halka açık etkinlikleri ve etkinlikler aracılığıyla toplulukların sosyal ve ekonomik refahında fark yaratma şeklini tanımlamaktır" (http://www.manchester.ac.uk/discover/social-responsibility/). Meslek edindirme çabaları ile ön plana çıkan üniversitelerin öğrencilerine mesleklerine ilişkin temel bilgileri vermenin yanında, içinde yaşadıkları topluma, edindikleri bilgi ve birikim doğrultusunda ne tür katkılar yapabilecekleri ve/veya yapmaları gerektiğini öğretmeleri gerektiği söylenebilir (Saran vd., 2011: 3745). Bu bağlamda öğrencilerde sosyal sorumluluk bilincinin geliştirilmesi, üniversitelerin diğer birimlerinde olduğu gibi meslek yüksekokullarında da önem arz etmektedir. Bugün yükseköğretimde sosyal sorumluluk bilincinin geliştirilmesi üzerine çalışan kurumlar için Brennan Weiss; bazı üniversitelerin, kendilerini, 77 ülkedeki 363 üniversitenin küresel Talloires Ağı üyeleri gibi, sivil ve toplumsal hizmet veya "sosyal yardım" alanlarında 'meşgul' kurumlar olarak gördüklerini belirtmektedir. Dünyanın her yerindeki üniversiteler, sosyal sorumluluklarını araştırma ve öğretim görevleri de dahil olmak üzere görev bildirgelerine entegre ederek, yükseköğretimin finansmanından sorumlu olan topluma geri verildiğinde daha iyi sonuçlar elde edildiğini ve edileceğini belirtmektedir.

(http://www.universityworldnews.com/article.php?story=20160811095808959).

Vallaeys (2013), sosyal sorumluluk faaliyetlerinde üniversitelerin bilmesi gereken hususları şu şekilde sıralamıştır. Vallaeys'e göre sosyal sorumluluk:

- Kurumların eylem ve davranışlarının toplumda yaratmış oldukları etkilerden sorumlu olma durumudur.

- Sürdürülebilir olmayan olumsuz etkileri ortadan kaldırmak ve sürdürülebilir kalkınma biçimlerini teşvik ederek toplumu sürdürülebilir kılmaya çalışan bir yönetim uygulaması gerektirir.

- Yasanın ötesinde veya dışında değildir. Yasal zorunluluklarla koordine çalışır.

- Teşhis edilen olumsuz etkiler üzerinde hareket etmek isteyen paydaşlar arasında koordinasyon gerektirir. Bu noktadan hareketle üniversitelerde geliştirilen sosyal sorumluluk projelerinin toplumsal ve yasal düzeyde oluşabilecek olumlu ve olumsuz etkileri ortaya koymaktadır. 
Türkiye'de eğitim kurumları eksenli gerçekleşen sosyal sorumluluk projeleri incelendiğinde:

- Mektup Kardeşliği Projesi,

- Kitap Toplama Kampanyası, "Okuyan Türkiye İçin” Kitap Bankosu,

- Bir El de Sen Uzat Anadolu’ya! "Bir Çocuk Bir Umut Projesi,

- Sağlığın Anahtarı Bisiklet Pedalları Projesi,

- Kitap Kütüphane Otomasyonu Projesi,

- Kırmızı Işıkta Kalp Durmasın, Sen Dur!,

- Çocuk Yüreklerine Siz de Dokunun Projeleri yapılan sosyal sorumluluk projelerinin sadece bir kısmını oluşturmaktadır (http://www.sosyalsorumluluk. org/sos/egitim/page/2/).

Türkiye'de üniversite öğrencilerinin sosyal sorumluluk süreçlerine katılımı, üniversite içinde ve üniversite dışında bulunan çeşitli örgütlenmeler ve yapılar aracılığıyla gerçekleşmektedir. Üniversite dışı yapılar arasında sivil toplum örgütleri, yurttaş oluşumlarının yürüttüğü çalışmalar ve kurumsal sosyal sorumluluk projeleri yer almaktadır. Üniversite bünyesindeki yapılar ise Öğrenci Topluluklar1/Kulüpleri, Öğrenci Konseyi, Toplumsal Duyarlılık Projeleri ve Topluma Hizmet Uygulamaları gibi dersler ve üniversite bünyesinde uygulanan çeşitli projelerden oluşmaktadır (Tog, 2013: 25).

Üniversite öğrencilerinde toplumsal duyarlılık ve farkındalık, işbirliği, dayanışma, etkili iletişim ve öz değerlendirme becerilerini destekleme, toplumsal sorumluluk bilinci ve özgüven oluşturma belirlenen hedeflerin başında gelmektedir. $\mathrm{Bu}$ kapsamda kurum bazında üniversitelerin, özelde üniversite öğrencilerinin sosyal sorumluluk projelerinde yer almaları çok yönlü fayda sağlamaktadır. Sosyal sorumluluk projeleri üniversitelerin asli görevini yerine getirmelerinde ve üniversite öğrencilerinin topluma katkı sağlayacak projelerde görev almalarına katkı sağlamaktadır. Bu bağlamda toplumsal sorunlar ile yüzleşen ve onlar üzerinde düşünme, tartı̧̧ma olanakları bulan üniversite öğrencilerinin toplumsal sorunlara karşı tutum ve davranışları da daha bilinçli olarak şekillenmektedir (Owen, 2000: 639).

Öğrenci Toplulukları, Öğrenci Konseyi, sınırları Yüksek Öğretim Kurumu Yönetmeliği ile belirlenen toplumsal fayda yününde faaliyetlerin de gerçekleştirilebileceği kurullar veya topluluklar olarak görülmektedir. Toplumsal Hizmet Projeleri, Toplumsal Duyarlılık Projeleri, Seçmeli Toplumsal Sorumluluk Dersleri, Üniversite Projeleri uygulamaları ise öğrencilerin bir ya da iki dönem boyunca seçmeli olarak alabilecekleri ve uygulamaya yönelik olarak belirlenen sayılı dersleri kapsamaktadır (Tog 2013: 4). Bahsi geçen bu kurullar ve dersler 
birer sosyal sorumluluk faaliyeti olarak üniversitelerde yer almaktadır. $\mathrm{Bu}$ bağlamda üniversite öğrencilerinin sosyal sorumluluk bilincinin geliştirilmesi yönünde çalışmalar, göreceli olarak -diğer bir deyişle- üniversitelere göre farkl1lık arz ederek gerçekleştirilmektedir.

\section{MEMYO SOSYAL DAYANIŞMA VE YARDIMLAŞMA KULÜBÜNE İLIŞKIN}

Türkiye'de yükseköğretimde meslek yüksekokulları geniş ve önemli bir yer tutmaktadır. Öğrencilerin mesleki eğitimlerini tamamlarken, aynı zamanda toplumsal ortak yaşama hazırlanması ve yaşamsal farkındalık kazanması için topluluklar -bir diğer deyişle- öğrenci kulüpleri eğitim hayatında değerlendirilmesi gereken bireysel kazanımlar için uygun bir uygulama alanı sağlamaktadır. Kısa bir tanımlama ile öğrencilerin ders dışı zamanlarında belirli bir hedef doğrultusunda eğitim, sağlık, spor, sosyal, bilim ve kültür faaliyetlerini "Öğrenci Kulübü Yönergesi”ne göre planlı ve organize şekilde gerçekleştirmek amacıyla bir araya gelerek oluşturdukları gruba "Öğrenci Kulübü” denmektedir (https://ybu.edu.tr/ sks/contents/files).

Marmara Ereğlisi Sosyal Dayanışmave Yardımlaşma Kulübü,Aralık2015 tarihinde gönüllü bir öğrenci tarafından bir öneri ile ilk faaliyetine başlamıştır. Öğrenci "www.kardesokullari.com" sitesinde Bitlis Güzelsu İlköğretimokulu'ndaki 32 öğrenci için talep edilen kırtasiye malzemesinin bir kampanya ile tedarik edilerek Bitlis'e gönderilmesini sınıfta önermiştir. Önerinin gerçekleştiği dersin öğretim elemanı bu tarihten itibaren kulüp çalışmalarında danışman görevi görmüştür. Gönüllü öğrenciler talep edilen malzemelerin bir listesini yaparak kampanyaya katılmak isteyen öğrencilere talep listesinde tamamlanamayan, eksik kalan malzeme isim ve rakamlarını bildirerek tedarik yöntemini kendileri oluşturmuştur. Kampanyanın başlatılmasını talep eden öğrenci, yönetimin iznini alarak yüksekokulun giriş alanında bir masa ve sandalye yerleştirerek gelen malzemeleri masada sergileme yöntemi ile kampanyaya katılımcı öğrenci sayısını bir hafta içinde hızlı bir şekilde yükselterek gereken kırtasiye malzemelerini ve fazlasını aynı hafta içinde tamamlamıştır.

Kulübün resmi olmayan ve organik bir biçimde kurallara veya yönetmeliklere bağlı kalmadan oluşan organizasyon şeması aşağıdaki şekilde belirtilen biçimdedir. Her bir halkanın birbiri ile etkileşimde olduğu ve fikir alışverişlerinin gerçekleştiği bu organizasyon şemasındaki her bir birim ile kulüp danışmanı -diğer bir deyişle- danışman öğretim elemanı çevresel bir birim olarak şemanın dışında yer almaktadır. Bu organizasyon şemasına ilişkin belirtilmesi gereken bir diğer husus, bu organizasyon biçiminin başlangıçtan itibaren aynı sistematikle işlerliğine devam ediyor olmasıdır. Bu bağlamda yazılı olmamasına karşın 
çalışmaların düzenli bir biçimde bu organizasyon ile hareket etmesi, kulübün bir diğer artı değeri olarak kayıt altına alınmıştır. Kulüp üyeleri topladıkları malzemeleri ihtiyaç listelerine uygun olarak bir araya getirdikten sonra, isim isim öğrencilere özel olarak paketlemektedir. Paketlerin üzerine her bir öğrencinin isimleri yazılarak gönderilen ihtiyaç kalemi -her ne ise- kişiye özel hale getirilmektedir. Kulüp üyeleri bu paketleri "hediye" olarak isimlendirmektedir.

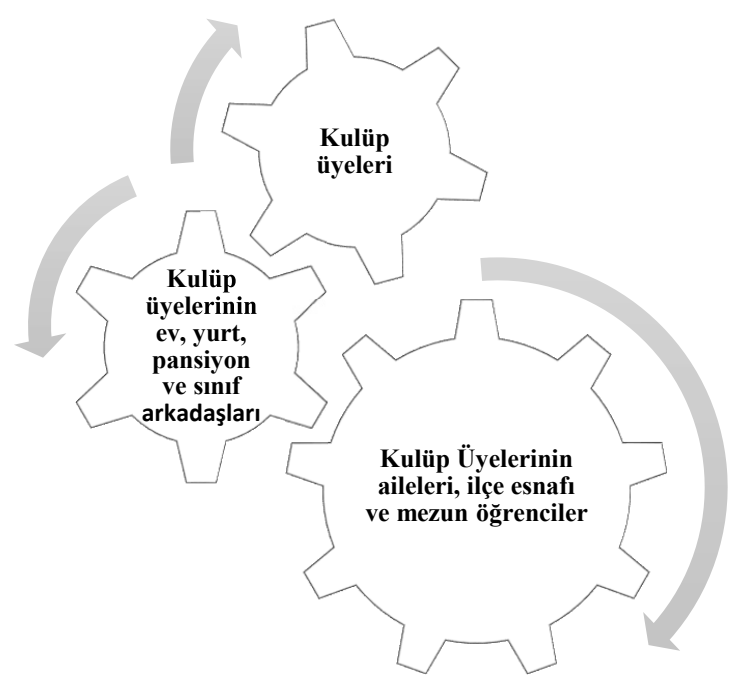

Şekil 1: MEMYO Sosyal dayanışma ve yardımlaşma kulübü organizasyon şemas1

İlk kampanyanın bir hafta içinde tamamlanarak toplanması, gereken malzemenin toplanmış olmasının verdiği sonuç ile öğrenciler tarafından yeni okul önerileri gelmeye başlamış, bu bağlamda kampanya süreklilikleri kulübün henüz oluştuğu dönemde pratik bir biçimde bir "kültür" haline dönüşmüştür. Öğrenciler dönemsel olarak iki okul için aynı zamanda çalışır hale gelmişlerdir. Diğer yandan kulübün yaptığı çalışmaların yerel ve ulusal basında yer alması, öğrencilerin çalışmalarına hız vermelerine ve çalışmalar sırasında teşvik olmalarına neden olmuştur. Kulübün kuruluş amacı, öğrencilerin ders dışı zamanlarında sosyal sorumluluk faaliyetlerine katılmalarını, ekip çalışmasını deneyimlemelerini ve başlangıçtan sona bir proje nasıl yürütülür öğrenmelerini sağlamaktır. Bu notadan hareketle kurulan kulüp 05.04.2019 tarihine gelindiğinde 150 okul, 4.000 üzerinde öğrenciye ulaşmayı başarmıştır. $\mathrm{Bu}$ araştırma çalışmasının yapıldığı dönemde de kulüp aktif çalışmalarına kuruluş dönemi bulunan öğrenciler mezun olmasına karşın, yeni katılan öğrencilerle ile kendini geliştirerek devam etmiştir. Kulübün aktif 10, mezun 5 öğrenci olmak üzere toplam olarak 15 üyesi bulunmaktadır. Kulüp çalışmalarına önderlik eden danışman hocaları, kampanyaların kayıt altına alınması ve koordinasyon noktasında roller üstlenmektedir. 


\section{ARAŞTIRMANIN YÖNTEMI}

Araştırmanın yöntemi derinlemesine görüşmedir. Daha önceden hazırlanan 12 soruluk föy katılımcılara uygulanarak cevaplar ses kaydına alınmıştır. Alınan ses kaydı çerçevesinde her bir soru kendi içinde analiz edilerek sonuçlar önce tablolara aktarılmış her bir tablonun altında öğretmen görüşleri detaylı bir şekilde verilmiştir. Araştırma, daha önce kulüp ile bağlantıya geçerek ihtiyaç sahibi öğrencilerine yardım gönderilen okulların öğretmenlerinden gönüllülük esasıyla belirlenen 10 öğretmen ile gerçekleştirilmiştir. Öğretmenler Muş, Şanlı Urfa, Adıyaman, Mardin, Siirt, Hakkâri, Ağrı şehirlerinde görev yapmaktadırlar. Yaşları 24-32 arasında değişmektedir. Diğer yandan öğretmenler Kayseri, Mardin, Denizli, Konya, Kütahya, Niğde, Erzurum, Niğde, Şanlı Urfa, Ağr1 ve Hakkâri nüfuslarına kayıtlıdırlar.

Çizelge1: Görüşmelerin gerçekleştirildiği öğretmenlerin demografik tanımları

\begin{tabular}{|l|l|l|l|}
\hline \multicolumn{1}{|c|}{$\begin{array}{c}\text { KATILIMCININ } \\
\text { KODU }\end{array}$} & \multicolumn{1}{|c|}{$\begin{array}{c}\text { NÜFUSA BAĞLI } \\
\text { OLDUĞU ŞEHIR }\end{array}$} & $\begin{array}{l}\text { GÖREV YAPTIĞI } \\
\text { ŞEHIR }\end{array}$ \\
\hline K1 & 26 & Kayseri & Muş \\
\hline K2 & 26 & Mardin & Şanlıurfa \\
\hline K3 & 24 & Denizli & Adıyaman \\
\hline K4 & 25 & Konya & Van \\
\hline K5 & 27 & Kütahya & Mardin \\
\hline K6 & 25 & Niğde & Siirt \\
\hline K7 & 27 & Erzurum & Muş \\
\hline K8 & 27 & Niğde & Şanlıurfa \\
\hline K9 & 26 & Şanlıurfa & Ağr1 \\
\hline K10 & 32 & Ankara & Hakkâri \\
\hline
\end{tabular}

Yukarıdaki tablonun detayları bölümün giriş kısmında açıklanmıştır.

MEMYO Sosyal Dayanışma ve Yardımlaşma Kulübünün çalışmaları sonrası yardım gönderdiği okullardaki öğretmenlerden kampanya sonrası görüşleri almak araştırmanın amacıdır. Bu bağlamda öğrencilerin, velilerin ve öğretmenlerin görüşlerinin detaylı olarak incelenerek kayıt altına alınması hedeflenmiştir.

\section{ARAŞTIRMANIN BULGULARI}

Derinlemesine görüşme yöntemi ile gönüllük esasıyla seçilen 10 öğretmen ile yapılan görüşme sonuçları aşağıdaki tablolarda frekanslar ile verilmiş ve her bir tablo hemen altlarında açıklanmıştır. Tabloların üst kısmında katılımcılara 
sorulan sorular görülmektedir. Katılımcıların kod sıralamaları yukarıda örneklem ve evrenin açıklandığı bölümde bulunmaktadır.

Çizelge 2: Daha önce bir sosyal sorumluluk projesinde çalıştınız mı?

\begin{tabular}{|l|c|c|}
\hline $\begin{array}{l}\text { SORU 1 Daha önce bir sosyal sorumluluk projesinde } \\
\text { çalıştınız mı? }\end{array}$ & Frekans & Yüzde (\%) \\
\hline Evet & 5 & $\% 50$ \\
\hline Hayır & 5 & $\% 50$ \\
\hline
\end{tabular}

Görüşmelerin gerçekleştirildiği öğretmenlerin 5'i daha önce herhangi bir sosyal sorumluluk projesinde yer almadığını belirtmiştir. Daha önce bir projede yer aldığını belirten öğretmenlerin ifadelerinden bazıları şu şekildedir.

K1 kodlu katılımc1; "Üniversitede okurken yer almıştım. Mezunu olduğum Sinop Üniversitesi’nin eski mezunlarının görev yaptığ köy okullarl için kırtasiye malzemesi toplayıp öğrencilere ulaştırmıştık.” ifadesini dile getirmiştir.

K5 kodlu katılımcı: "Fidan dikimi ve Kızılay için kan bağışında görev aldım." şeklide proje katımlı olduğunu ifade etmiştir.

Çizelge 3: Sosyal Dayanışma ve Yardımlaşma Kulübü çalışmalarından nasıl haberdar oldunuz

\begin{tabular}{|l|c|c|}
\hline $\begin{array}{l}\text { SORU 2 MEMYO Sosyal Dayanışma ve Yardımlaşma } \\
\text { Kulübü çalışmalarından nasıl haberdar oldunuz? }\end{array}$ & Frekans & Yüzde (\%) \\
\hline Sosyal medyadan & 7 & $\% 70$ \\
\hline Bir arkadaşım aracılığıyla & 3 & $\% 30$ \\
\hline
\end{tabular}

Katılımcı öğretmenler kulübün çalışmalarına ilişkin bilgiye ulaşma yolu olarak sosyal medya ve bir tanıdık aracılığıyla kategorilerinde cevap vermiştir. Katılımcıların cevapları detaylandırıldığında aşağıdaki veriler sıralanabilir.

K3 kodlu katılımc1: "Tanıdı̆̆ım bir meslektaşım bahsetti. Onun okuluna yardım gönderildiğini anlatınca, 'Ben de, biz de istesek yardım ederler mi' diye sordum. Sonra bir telefon ile kulüp üyesi bir ögrenciyle irtibata geçtim. İhtiyaç listemizi yolladıktan bir buçuk hafta sonra tüm ihtiyaçlarımız gönderildi." yanıtını vermiştir. 
K2 kodlu kat1lımc1: "kardesokullari.com sitesine ben bir mesaj birakmıştım, bana oradan ulaştınız. Bir öğrenciniz bana mesaj göndererek ihtiyaçlarımızın karşılanıp karşılanmadiğını sordu, ben de karşılanmadı̆̆ını söyleyince ihtiyaç listemizi bizden istedi ve ihtiyaçlarımızı tek tek paketleyerek bize yolladılar." biçiminde tecrübesini dile getirmiştir.

K10 kodlu katılımc1: 'Instagram'da 'köy okullarına yardım' etiketi ile buldum. Gönderileri paylaşan kişiye mesaj gönderdim, hemen cevap verdiler. İhtiyaçlarımızı ögrenerek yolladılar." sözleriyle kulübe ulaşma tecrübesini dile getirmiştir. Bu cevaplar kulüp faaliyetlerinin yaygınlaşması noktasında sosyal medya uygulamalarının önemini ortaya koymaktadır.

Çizelge 4: MEMYO Sosyal Dayanışma ve Yardımlaşma Kulübü, öğrencilerinizin hangi ihtiyaçlarına cevap verdi

\begin{tabular}{|l|c|c|}
\hline $\begin{array}{l}\text { SORU 3 MEMYO Sosyal Dayanışma ve Yardımlaşma } \\
\text { Kulübü, öğrencilerinizin hangi ihtiyaçlarına cevap verdi? }\end{array}$ & Frekans & Yüzde (\%) \\
\hline Kırtasiye & 1 & $\% 10$ \\
\hline Bot & 5 & $\% 50$ \\
\hline Kırtasiye, bot & 2 & $\% 20$ \\
\hline Oyuncak & 1 & $\% 10$ \\
\hline Mont & 1 & $\% 10$ \\
\hline
\end{tabular}

Kulüp ihtiyaç sahibi okulların belirttikleri listelere uygun çalışarak malzeme toplamasının sonucu olarak bot, kırtasiye, oyuncak, mont gibi farklı ihtiyaçlara cevap vermiştir. Bu bağlamda öğretmenlerin yanıtları aşağıdaki gibidir.

K2 kodlu katılımc1: "Sadece bot ihtiyacı vardı öğrencilerimin... Ama kulüp kırtasiye malzemesi de gönderdi. Her bir paket çocukların ismine özel hazırlanmıştı. Aslında ihtiyaç karşılamaktan daha çok, o hediye paketlerine sevindi çocuklarım ... " biçiminde tecrübesini dile getirmiştir.

Çizelge 5: Kulüp üyelerinin hazırladıkları paketler size ulaştığında siz neler hissettiniz

\begin{tabular}{|l|c|c|}
\hline $\begin{array}{l}\text { Soru 4 Kulüp üyelerinin hazırladıkları paketler size } \\
\text { ulaştığında siz neler hissettiniz? }\end{array}$ & Frekans & Yüzde (\%) \\
\hline Mutlu oldum. & 7 & $\% 70$ \\
\hline Gurur duydum & 3 & $\% 30$ \\
\hline
\end{tabular}


Öğretmenlere kulüp üyelerinin yolladıkları paketler kendilerine ulaştığında ne hissettikleri sorulmuş ve öğretmenlerden genel olarak mutlu oldum ve gurur duydum cevabı alınmıştır. Cevapların detayları aşağıda yer almaktadır.

K7 kodlu katılımcı: "Özenle hazırlanmış paketlerdi. Çocukların açarkenki heyecanı görülmeye değerdi. Ben de onlar kadar mutlu oldum. Böyle insanlar bizlere umut oluyor. Iş̧imize daha büyük bir tutkuyla bağlanmamızı să̆llyor." şeklinde tecrübesini ifade etmiştir.

K9 kodlu katılımcı: "En az çocuklar kadar mutlu olmuşumdur. Ülkemizde muhtaca yardım bilincinin yaşıyor olması özellikle de bu kampanyayı üniversite ögrencilerinin yürütmesi çok gurur ve onur verici." sözleriyle duygularını ifade etmiştir.

K2 kodlu kat1lımc1: "Özenle hazırlanmış paketleri görünce hâlâ bu kadar ince düşünceli insanların olduğunu bilmek huzur ve gurur verdi." sözleriyle tecrübesini dile getirmiştir.

K10 kodlu katılımc1: "Göreve başlamadan önce böyle yardımların gerçekten olabileceğine inanmıyordum. Böyle yardımların sadece reklam amaçl yapıldiğını dahi düşünüyordum. Ama bize umut olan öğrencilerin var olduğunu görmek ögrencilerimle birlikte beni çok mutlu etti. " sözleriyle kendini ifade etmiştir.

K6 kodlu katılımc1: "Çok sevindim bu kadar çabuk gelmesi ve hediye paketlerinin isim isim koyulması beni çok şaşırttı. Gerçekten benim ögrencilerim için hazırlanmışt. Bu kadar vakit ve emek harcanması gelen malzemelerin maddi değerinin çok ötesindeydi. Koliyi açtı̆̆ım zaman hissettiklerimi size anlatmam gerçekten mümkün değil inanın..." sözleriyle cevap vermiştir.

Çizelge 6: Hazırlanan paketleri öğrencilerinize dağıttığınızda öğrencilerinizin genel duygu durumunu nasıl ifade edersiniz?

\begin{tabular}{|l|c|c|}
\hline $\begin{array}{l}\text { SORU 5 Hazırlanan paketleri öğrencilerinize } \\
\text { dağıttı̆̆ınızda öğrencilerinizin genel duygu durumunu } \\
\text { nasıl ifade edersiniz? }\end{array}$ & Frekans & Yüzde (\%) \\
\hline Şaşırmış & 2 & $\% 20$ \\
\hline Mutlu & 7 & $\% 70$ \\
\hline Şaşkın ve mutlu & 1 & $\% 10$ \\
\hline
\end{tabular}


Öğretmenlere gelen hediye paketleri dağıtıldıktan sonra öğrencilerin duygu durumu sorulmuştur. Öğretmenler; mutlu, şaşkın ifadeleriyle öğrencilerinin duygularını ifade etmişlerdir.

K7 kodlu katılımc1; "Paketler geldiğinde heyecan doruktaydl. Oldukça sabırsızlandılar. İsimlerinin üzerine yapıştırılan gülen yüzleri alınlarına yapıştırdılar. Montlarına sarlldılar. Bir an önce eve gidip annelerine göstermek istedikleri söylediler." sözleriyle öğrencilerinin duygu durumunu ifade etmiştir.

K6 kodlu katılımcı: "Kutuyu görür görmez heyecanlandılar. Önce çok şaşırdılar paketlerini açtıklarında ise çok mutlu oldular. Hemen denediler." sözleriyle öğrencilerinin duygularını ifade etmiştir.

K1 kodlu kat1lımc1; "Her bir öğrencimin üzerinde isimleri yazan paketlerle buluştuğu an mutlulukları gözlerinden okunuyordu. Kendileriniçok özel hissettikleri belliydi. Çoğu ilk defa hediye paketi görüyordu. Önce paketlerle ne yapacaklarını bile bilemediler. Paket kâğıtlarına zarar vermekten korktular. Sonra paketleri açmalarını söyleyince çığlık çı̆̆lı̆̆a heyecanla paketleri açtılar. Mutlulukları tarif edilemez bir durumdu..." sözleriyle öğrencilerinin duygu durumunu ifade etmiştir.

Çizelge 7: Öğrencileriniz paketlerin Tekirdağ'dan geldiğini öğrendiğinde neler dedi?

\begin{tabular}{|l|c|c|}
\hline $\begin{array}{l}\text { SORU 6 Öğrencileriniz paketlerin Tekirdağ'dan } \\
\text { geldiğini öğrendiğinde neler dedi? }\end{array}$ & Frekans & Yüzde (\%) \\
\hline Tekirdağ'ın nerede olduğunu öğrendiler. & 7 & $\% 70$ \\
\hline Tekirdağ'ın uzaklığına hayret ettiler. & 3 & $\% 30$ \\
\hline
\end{tabular}

Öğretmenlere paketlerin Tekirdağ Namık Kemal Üniversitesi’ndeki öğrenciler tarafından gönderildiği söylendiğinde öğrencilerin ne dediği sorulmuştur. Öğretmenler Tekirdağ’ın bulundukları ile uzaklığını merak ettiklerini uzaklığın öğrencilerini hayrete düşürdüğünü ifade ettiler.

K1 kodlu katılımc1: "1. sinıf ögrencisi olmalarından dolayı o kadar masumlardı ki; isimlerini nereden bilip paketlerin üzerine yazdı̆̆ınızı merak ettiler daha çok. Tekirdă̆'ın başka bir şehir olduğunu belki 2. sınıf öğrencisi olsalar daha iyi anlayabilirlerdi." biçiminde düşüncelerini ifade etmiştir.

K7 kodlu katılımc1: "Haritadan Tekirdağ'ı bularak İstanbul, Ankara, Adiyaman gibi bir il olduğundan bahsettim. Sadece birkaç şehir bilen ögrencilerimin biranda dünyaları genişledi." sözleriyle durumu ifade etmiştir. 
K2 kodlu katılımc1 öğrencilerinin neler dediğine ilişkin olarak: "Öğretmenim taa oradan nasll gönderdiler? Bizi nereden taniyorlar? Bizim bunlara ihtiyacımız olduğunu nereden bildiler? Sizin arkadaşlarınız mı bize yardım edenler gibi soruların cevaplarını merak ettiler daha çok... Tekirdăg'dan geldiğini söylediğimde uzaklı onları hayrete düşürdü." ifadelerini kullanmıştır.

K8 kodlu katılımc1: "Tekirdağ adını ilk defa duydular; böyle bir ilden haberdar değillerdi. Ama şimdi hepsi haritadan Tekirdağ'ın yerini hemen gösterebiliyor. Artık hepsi Tekirdağ'ı sizinle tanıyor ve biliyor." sözleriyle öğrencilerinin verdiği tepkiyi dile getirmiştir.

Çizelge 8: Size bu yardımlara ilişkin olumlu ya da olumsuz görüş bildiren veliniz oldu mu? Öğrenci velilerinin tepkileri nasıl oldu?

\begin{tabular}{|l|c|c|}
\hline $\begin{array}{l}\text { SORU 7 Size bu yardımlara ilişkin olumlu ya da } \\
\text { olumsuz görüş bildiren veliniz oldu mu? Öğrenci } \\
\text { velilerinin tepkileri nasıl oldu? }\end{array}$ & Frekans & Yüzde (\%) \\
\hline Olumlu tepkiler aldım. & 8 & $\% 80$ \\
\hline Hiç bir dönüt almadım. & 2 & $\% 20$ \\
\hline
\end{tabular}

Kulüp çalışmaları çerçevesinde yardım gönderilen öğrencilerin velilerinin tutumuna ilişkin sorulan soruda öğretmenlerin önemli bir bölümü olumlu tepkiler aldıklarını ifade etmişlerdir.

K1 kodlu katılımc1: "Arayarak ve okula gelerek teşekkür eden veliler de oldu; bu yardımların nereden geldigini sormayanlar da..." sözleriyle durumu ifade etmiştir.

K7 kodlu katılımc1: "Bazı velilerim birebir arayarak teşekkür ettiler. Ertesi gün teşekkür için köy peyniri, tereyağı getiren dahi oldu... Sanırım bu kampanyadan en kârlı ben çıktım. Teşekkürler MEMYO. ” sözleriyle soruyu cevaplamıştır.

K3 kodlu katılımc1 velilerinin tepkilerini; "Velililerimizin maddi profilleri düşük olduğu için çocuklarının karşılayamadığı bir ihtiyacını giderildiği için teşekkürlerini ilettiler. Sonuçta gönderilen malzemeleri biz burada kasabadan dahi satın alamayız. Şehre olan uzaklığımız da düşünüldüğünde veliler açsısından bu yardımların önemi oldukça yüksek..." sözleriyle açıklamıştır. 
Çizelge 9: Sizce yapılan bu yardım çalışmaları öğrencilerinizin "Milli Birlik Bilinci" gelişimine katkı sağlar mı?

\begin{tabular}{|l|c|c|}
\hline $\begin{array}{l}\text { SORU 8 Sizce yapılan bu yardım çalışmaları } \\
\text { öğrencilerinizin "Milli Birlik Bilinci” gelişimine katk1 } \\
\text { sağlar mı? }\end{array}$ & Frekans & Yüzde (\%) \\
\hline Evet sağlar. & 8 & $\% 80$ \\
\hline Şimdi değil, ama ileride sağlar. & 2 & $\% 20$ \\
\hline
\end{tabular}

Öğrencilerin milli birlik bilincini geliştirip geliştirmeyeceğine dair öğretmenlerin inançları sorulduğunda öğretmenlerin tamamının bu yapılan sosyal sorumluluk çalışmalarının milli birlik bilincini oluşturacağı ve güçlendireceği cevabı alınmıştır.

K2 kodlu katılımc1: "Kesinlikle sağlar. Benim çocuklarım sürekli onlara yardım gönderen ăgabeyleri ve ablalart için dua ediyor. Birilerinin onların okuması için yardım ettiğinin farkındalar; bu nedenle birbirlerini görmeseler de aynı ülkenin vatandaşı olmanın ne demek olduğunu hissettiler bence.." sözleriyle cevap vermiştir.

K5 kodlu katılımc1: "Benim öğrencilerim bunu tam olarak anlayabilecek yaşta değiller; fakat ileride mutlaka bunu hatırlayacaklar. Bu da eminim onlarda milli birlik bilinci için bir tohum olacak..." sözleriyle durumu ifade etmiştir.

K8 kodlu katılımc1: "Elbette, aynı anda mutlu olabilmeyi, paylaşmayı ve yardımlaşmayl ögrendiler. Hepsinin bir bütün olduğunu hissettirdiğini düşünüyorum. Sonuçta Adlyaman-Tekirdăg arası neredeyse $1.300 \mathrm{~km} \ldots \mathrm{Bu}$ mesafe hem Türkiye'nin büyüklüğ̈̈nü onlara hissettirdi hem de duygu olarak aslında ne kadar yakın olduğumuzu oralardaki insanlarla... Öğrencilerim bu duyguyu kesinlikle hissettiler." cevabını vermiştir.

K1 kodlu katılımc1: "Paketleri onlara dağıttıktan sonra onlara, bizlere bu yardımları yapan insanların aslında bize çok uzak olduğunu, ama bu mesafelere rağmen bizim ihtiyaç çağrımıza duyarsız kalmadığınızı anlattım. Millet olmanın, aynı toplumda yaşamanın gereklerini, yardımlaşmanın önemini konuştuk hep birlikte. Bu da ögrencilerimin milli birlik gelişimlerine mutlaka etki etti elbette..." biçiminde cevap vermiştir. 
K3 kodlu katılımc1: "Arada kilometrelerce mesafe olmasina karşın doğudaki kardeşlerine yardım elini uzatan siz değerli eğitmenlerin ve kardeşlerimin başlattlğ bu tarz sosyal sorumluluk projeleri, elbette milli birlik bilincinin gelişimine katkr sağlayacaktır. Keşke üniversitede okurken benim de böyle projelerde çalışma firsatım olsaydı. Bu çalışmalar Anadolu'yu birbirine bağlar." sözleriyle yanıt vermiş̧ir.

Çizelge 10: Sizce bu çalışmalar öğrencilerinizin "Sosyal Sorumluluk Bilinci" gelişimine etki eder mi?

\begin{tabular}{|l|c|c|}
\hline $\begin{array}{l}\text { SORU 9 Sizce bu çalışmalar öğrencilerinizin "Sosyal } \\
\text { Sorumluluk Bilinci” gelişimine etki eder mi? }\end{array}$ & Frekans & Yüzde (\%) \\
\hline Evet. & 10 & $\% 100$ \\
\hline Hayır. & 0 & $\% 0$ \\
\hline
\end{tabular}

Bir diğer soru ise sosyal sorumluluk bilincini etkileyip etkilemeyeceği yönünde sorulmuş, öğretmenlerin tamamı öğrencilerinin sosyal sorumluluk bilincinin bu çalışmalar ile artırılabileceğini belirtmiştir.

K1 kodlu katılımcı: "Ben öğretmenleri olarak onlara ilerde aynı şekilde onların da ihtiyaç sahiplerine bu şekilde destek olmalarl gerektiğini vurguladım. Şu an nasıl tanımadikları insanların desteğiyle eksiklerini giderdilerse, ilerde kendilerinin de ihtiyacı olan çocuklara yardım edeceklerini söylediler." biçiminde cevap vermiştir.

K3 kodlu katılımc1: "Öğrencilerimiz kendilerine yapılan bu desteklere karşı duyarsı kalmayacaktır. Illeride şartlar oluştuğunda ögrencilerimin de bu tarz sosyal sorumluluk projelerinde görev alacağını düşünüyorum." sözleriyle düşüncelerini ifade etmiştir.

K9 kodlu kat1lımc1: "Kesinlikle etki eder. Çocuk böyle projeler sayesinde karşısındakini, tanımadiğı birisi de olsa ve yardıma muhtaçsa yardımcı olmayı, elinden geleni yapmay kendisine vazife saylyor. Bu nedenle ögrrencilere örnek olmak en iyi ögretme yolu. Bunu unutmaları mümkün değil." sözleriyle cevap vermiştir.

K2 kodlu katılımcı: "Onlar büyüyünce biz de başkalarına yardım edelim demeye başladılar şimdiden... Hatta paketlerden biri fazla çıktı koliden, bana, 'Öğretmenim biz de bunu başka köye gönderelim mi?' diye sordular. Benim çocuklarımda sosyal sorumluluk bilinci şimdiden oluştu bile diyebilirim." yanıtını vermiştir. 
Çizelge 11: Paket size ulaştığında veya daha sonrasında yürütülen bu çalışmaya ilişkin unutamayacağınız bir anınız oldu mu? Kısaca bahseder misiniz?

\begin{tabular}{|l|c|c|}
\hline $\begin{array}{l}\text { SORU 10 Paket size ulaştı̆̆ında veya daha sonrasında } \\
\text { yürütülen bu çalışmaya ilişkin unutamayacağınız bir } \\
\text { anınız oldu mu? Kısaca bahseder misiniz? }\end{array}$ & Frekans & Yüzde (\%) \\
\hline Evet. & 5 & $\% 50$ \\
\hline Hayır. & 5 & $\% 50$ \\
\hline
\end{tabular}

Öğretmenlerin bu çalışma ile unutamadığı bir anıları varsa anlatmaları istenmiştir. Bu noktada beş öğretmen yaşadığı anıyı paylaşmıştır. Bunlardan üç tanesi aşağıda verilmiştir.

K2 kodlu katılımc1 unutamadığ 1 anısının olduğunu belirtmiş ve şu şekilde anlatmıştır: "Illkyll paketler geldi, ben onunla kalır sanmıştım. Ama İkinci yll ben herhangi bir talepte bulunmadan okulun ihtiyacının olup olmadiğı soruldu. $O$ an çok duygulanmıştım."

K3 kodlu katılımc1: "Paketler isme özel hazırlandı̆ğndan bir öğrencimin kendi paketine sarllip bu paket benim, üzerinde ismim yazlyor demesi beni çok etkilemişti. Illk defa hediye paketi görüyordu. Renkli kap kâğıtları ve kendi adının yazılı olduğu bir etiket... Bunu nasıl unuturum." şeklinde anısını dile getirmiştir.

K6 kodlu katılımc1: "Kutuyu açtığımda renkli paketlerin olduğunu ve herkese ayrı isim yazılı olduğunu görmek beni çok mutlu etti; bunu hiç unutmam. Bir de botlarını çok beğenen bir kız öğrencim, 'Öğretmenim evde küçük kardeşim de bunu çok sever, ona da verir misiniz bundan; o şimdi ağlar' demesi de beni çok duygulandırmıştı." diyerek anısını paylaşmıştır.

Çizelge 12: Sizce üniversite öğrencilerinin başlattığı bu çalışmalar ülkemizde bölgesel ve etnik ayrımcılıkların ortadan kalkması üzerine olumlu bir etki taşır mi? Neden?

\begin{tabular}{|l|c|c|}
\hline $\begin{array}{l}\text { SORU 11 Sizce üniversite öğrencilerinin başlattığ1 } \\
\text { bu çalışmalar ülkemizde bölgesel ve etnik } \\
\text { ayrımc1lkların ortadan kalkması üzerine olumlu bir } \\
\text { etki taşır mı? Neden? }\end{array}$ & Frekans & Yüzde (\%) \\
\hline Evet. & 8 & $\% 80$ \\
\hline Hayır. & 2 & $\% 20$ \\
\hline
\end{tabular}


Bir diğer soru ise sosyal sorumluluk projesinin bölgesel ve etnik ayrımcılığın ortadan kalkmasında olumlu etki taşıyı taşımayacağı yönünde sorulmuştur. Öğretmenlerin önemli çoğunluğu olumlu yönde etki sağlayacağı yönünde cevap vermiştir.

K7 kodlu katılımc1: "Evet. İnsanların nerede yaşadığı, nasıl göründüğü önemsenmeden yardımlaşıla-bileceği, birbirlerinin mutluluklarına ortak olabileceğini görmeleri sağlar. Mutluluk, paylaşma; bunlar ortak paydada buluşturur. Bunu da gençlerin yaptı̆̆ını bilmek etkiyi de çok daha artırır bence..." sözleriyle fikrini dile getirmiştir.

K10 kodlu katılımc1: "Keşke öyle olsa... Ama ayrımcilıkları ortadan kaldırmak için siyasilerin çalışması gerek; ögrenciler bu konuda kelebek etkisi yaratır ancak..." biçiminde eleştirel bakış açısını dile getirmiştir.

K3 kodlu kat1lımc1: "Dil, din, ırk ayrımı gözetmeksizin milli bir şuurla hareket edilerek gerçekleştirilen sosyal sorumluluk projeleri, bu bölgelerde yaşayan insanların var olan ön yargılarını da ortadan kaldırlacaktır. Ben kesinlikle faydalı olduğunu düşünüyorum. ” sözleriyle fikrini dile getirmiştir.

K2 kodlu kat1lımc1: "Bu konuda bir şey diyemeyeceğim. Çünkü çocukken zaten bu etnik ayrımı yapan yok. Sorun büyüyünce başlıyor. Keşke hep şu anki gibi masum kalksalar; ama maalesef büyüdükçe çevrenin etkisiyle düşünceleri değişiyor." sözleriyle fikrini dile getirmiştir.

Çizelge 13: Sizce üniversite öğrencilerinin başlattığı bu proje ile sizin ögrencilerinizin de üniversiteli olduklarında sosyal sorumluluk projelerine katılmasına etki eder mi? Neden?

\begin{tabular}{|l|c|c|}
\hline $\begin{array}{l}\text { SORU 12 Sizce üniversite öğrencilerinin başlattı̆̆ } \\
\text { bu proje ile sizin öğrencilerinizin de üniversiteli } \\
\text { olduklarında sosyal sorumluluk projelerine katılmasına } \\
\text { etki eder mi? Neden? }\end{array}$ & Frekans & Yüzde (\%) \\
\hline Evet. & 8 & $\% 80$ \\
\hline Umarım. & 2 & $\% 20$ \\
\hline
\end{tabular}

Başlatılan bu sosyal sorumluluk projesiyle yardım alan öğrencilerin ileride sosyal sorumluluk projelerinde yer alıp almayacağ 1 konusunda görüşleri istenen öğretmenlerin önemli bir çoğunluğu öğrencilerinin sosyal sorumluluk projelerini katılacağını düşünmektedir. 
K9 kodlu katılımc1: "Edeceğini düşünüyorum. Çocuk bunu unutmayacak ve, 'Zamanında bize yardım etmişlerdi. Şu anda yardıma muhtaç, benim çocukluğumda olduğum gibi birçok çocuk vardır' diye düşünerek benim de bunu yapmam gerekiyor diyecektir." sözleriyle fikrini dile getirmiştir.

K10 kodlu katılımc1: "Evet. Bu bilince çok önceden ulaşmış olacaktır. Kendi mutluluğunu hatırlaması bile bu projelere katılmak istemesinde büyük etken olacaktır." sözleriyle görüşünü ifade etmiştir.

K4 kodlu katılımc1: "Biz elbette pozitif düşünmek istiyoruz. Çünkü emek veriyoruz. Umarım etkili oluyordur, umarım etkili olacaktır.” sözleriyle cevap vermiştir.

K1 kodlu katılımc1: "Edeceğini düşünüyorum, edeceğine inanıyorum. Çünkü ilkokul yıllarımızın hayatımızda ne kadar büyük bir yeri ve etkisi olduğunu biliyorum. Üzerinden 20 sene geçmiş olmasına rağmen hâlâ 1. sınıfa başladı̆̆ günü unutmamış bir sını öğretmeni olarak; öğrencilerimin isimlerine özel gelen bu yardım paketlerini aldıkları ve o malzemeleri özenle kullandıkları o zamanları seneler sonra hatırlayacakların biliyorum. Elimden geldiğince merhametli, duyarl, paylaşımcı ögrenciler yetiştirmek için mücadele veriyorum ve seneler sonra onların da aynı hassasiyetle insanların yardımına elinden geldiğince koşan bireyler olmalarını diliyorum." biçiminde görüşlerini ifade etmiştir.

\section{SONUÇ}

Mesleki eğitimlerini tamamlamak üzere yükseköğretim kurumlarını tercih eden öğrencilerin toplumsal sosyal sorumluluk kavramlarının geliştirilmesi amacıyla kurulan bir kulübün çalışmaları, bu araştırmanın içeriğidir. Yapılan çalışmada, öğrencilerin üç yılı aşkın süre zarfında yardım gönderdiği okullarda görev yapan öğretmenlerle görüşmeler sağlanmış ve yapılan proje çalışmasının yansımaları ölçümlenmeye ve kayıt altına alınmaya çalışılmıştır. Bu bağlamda öğretmenlere kampanya sonucunda okullarına yardım malzemeleri ulaştıktan sonra yaşadıkları, öğrencilerin tepkileri, velilerin izlenimleri ve kendi görüşlerinin özellikle sosyal sorumluluk bilinci ve milli birlik bilinci gelişimi noktasında neler olduğu sorulmuş ve yanıtlar alınmıştır.

Öğretmenlere kulüp üyelerinin yolladıkları paketler kendilerine ulaştığında ne hissettiklerisorulmuşveöğretmenlerdengenel olarakmutluoldumvegururduydum cevabı alınmıştır. Öğretmenler, öğrencilerin duygu durumunu ise mutlu, şaşkın ifadeleriyle dile getirmişlerdir. Öğrencilere paketlerin Tekirdağ' dan gönderildiği söylendiğinde, mesafelere öğrencilerin hayret ettiği ifadesi kayıt altına alınmıştır. Velilerin önemli bir çoğunluğunun olumlu tepki verdiği belirtilmiştir. Diğer 
yandan öğretmenler bu çalışmalar ile kendi öğrencilerinin milli birlik ve sosyal sorumluluk bilinci kavramlarının olumlu yönde etkileneceğini düşündüklerini belirtmişlerdir. Aynı zamanda bölgesel ve etnik ayrımcılığın ortadan kalkmasına neden olabileceği de öğretmenlerin önemli çoğunluğu tarafından desteklenmiştir. Öğretmenlerin önemli bir çoğunluğu, öğrencilerinin ilerideki yaşamlarından bu projeden etkilenerek sosyal sorumluluk projelerine katılacağını düşünmektedir.

Toplumsal sosyal sorumluluk kavramının temel eğitim aşamaları içinde yer almasına ilişkin çalışmalar, farklı proje örnekleriyle karşımıza çıkmaktadır. Bugün doğa, kadına şiddet, tarihi koruma, hayvan haklarını savunma gibi sıralanacak birçok konu üzerinde sosyal sorumluluk çalışmaları, sivil toplum kuruluşları tarafından yürütülmektedir. Toplum Gönüllüleri Vakfı'nın yayınladığı raporlarda da sıklıkla karşımıza çıkan gönüllülük esasının sosyal sorumluluk kavramıyla yakından ilişkisi vardır. Gönüllülüğün artması, ancak farkındalık oluşturulmasıyla sağlanacaktır. Bu noktada sosyal sorumluluk üzerine geliştirilen her nevi projeler, özellikle eğitim-öğretim dönemleri içinde, eğitimin her basamağında olmalıdır. Bu çalışmada bahsi geçen proje, örnek bir proje örneği olarak tarafımdan gerçekleştirilen akademik çalışmalarda yer almıştır. Amacı meslek yüksekokulu öğrencilerini takım çalışması, proje yönetimi gibi alanlarda geliştirmeyi amaçlayan proje, zaman içinde toplumdan geri dönüşler almaya başlamış; bu geri dönüşler ise bu akademik çalışmanın konusunu oluşturmuştur. Yapılan proje çalışması yansımaları farklı şehirlerde görev yapan öğretmenlerin söylemleri kayıt altına alınarak detaylandırılmıştır. Görülen sonuç, projenin sosyal sorumluluk farkındalığının ve milli birlik bilincinin gelişimi noktasında rolü olduğudur.

Sosyal sorumluluk projeleri bugün eğitimin her basamağında yer alması gereken, ders müfredatlarında, öğrenci kulüpleri kapsamında daha yoğun bir şekilde ele alınması gereken bir nitelik taşımaktadır. Toplumsal sosyal sorumluluk kavramı, yaşamın her döneminde yer almalı, bu bağlamda tüm eğitim kurumlarında desteklenmelidir. MEMYO Sosyal Dayanışma ve Yardımlaşma Kulübünün başlatmış olduğu çalışmalar ile dört binin üzerinde öğrenci yardım faaliyetleri çerçevesinde desteklenmiş, bu bağlamda sosyal sorumluluk ve milli birlik bilinci gelişimleri desteklenmiştir. Üniversite öğrencilerinin ders dışı zamanlarını etkin bir biçimde kullanmalarını sağlayan proje, aynı zamanda sahadan olumlu yansımalar almaktadır. Bu bağlamda çift yönlü bir kazanım içinde olan bu tip projelerin yükseköğretim kurumlarında yaygınlaştırılması için çalışmaların artırılması gerekmektedir. Hem toplumsal milli birlik gelişimi hem de sosyal sorumluluk bilinci gelişimi için gerekli bu adımların atılması ivedilik taşımaktadır. 


\section{KAYNAKÇA}

Balta, P.F. Halkla İlişkiler Nedir? Beta, İstanbul, 2012.

Sabuncuoğlu, Z. İşletmelerde Halkla İlişkiler. Aktüel Yayınları, Bursa, 2004.

http://www.sosyalsorumluluk.org/kurumsal-sosyal-sorumlulugun-turkiyedegelisimi/ Erişim tarihi: 08.01.2019.

Göcenoğlu, C., Girgin, Z.K. Kurumsal Yönetişimin Türkiye'deki Kurumsal Sosyal Sorumluluk Uygulamalarına Olan Etkileri. IV. Orta Anadolu işletmecilik Kongresi, TOBB Ekonomi ve Teknoloji Üniversitesi, ss: 72-79, Ankara, 2005.

Hotamışl, M., Çă̆, A., Menteşe, A. ve Yörük, E. Kurumsal Sosyal Sorumluluk Bilinci: Afyon Kocatepe Üniversitesinde Karşılaştırmalı Bir Araştırma, Elektronik Sosyal Bilimler Dergisi, 9(34): 280-299. 2010. www.esosder.org

Töremen, F. Öğretmen Adaylarının Sorumluluk Eğitimi, Kuram ve Uygulamada Eğitim Bilimleri, 11: 263-277, 2011.

http://www.manchester.ac.uk/discover/social-responsibility/ Erişim tarihi 31.12.2018.

Saran, M., Coşkun, G., InalZorel, F. ve Aksoy, Z. Üniversitelerde Sosyal Sorumluluk Bilincinin Geliştirilmesi: Ege Üniversitesi Topluma Hizmet Uygulamaları Dersi Üzerine Bir Araştırma, Yaşar Üniversitesi Dergisi. 22(6): 3732-3747. 2011.

http://www.universityworldnews.com/article.php? story $=20160811095808959$ Erişim tarihi 31.01.2019.

Vallaeys, Francois Defining social responsibility: A matter of philosophical urgency for university. Global university network for innovation. from http:// www.guninetwork.org/resources/he-articles/definingsocial-responsibility-amatter-of-urgency-for-philosophy-and-universities, 2013.

http://www.sosyalsorumluluk.org/sos/egitim/page/2/Erişim tarihi 08.01.2019.

Üniversitelerde Sosyal Sorumluluk ve Sosyal Girişimcilik Pilot Projesi [Rapor], Toplum Gönüllüleri Vakfi, Proje Raporu, İstanbul, 2013.

Owen, Diana Service Learning and Political Socialization [Dergi]. American Political Science Association. 33 (3): 639-640, 2000.

https://ybu.edu.tr/sks/contents/files Erişim tarihi 04.05.2018. 


\title{
TEKNOLOJI VE SIBBER GÜVENLİK: DİJITAL TOPLUMUN GELECEĞİ
}

\author{
İrfan ATASOY \\ İstanbul Kültür Üniversitesi, Türkiye \\ info@irfanatasoy.comt.tr \\ https://orcid.org/0000-0002-1429-2126 \\ Doç. Dr. Okan ORMANLI \\ İstanbul Kültür Üniversitesi, Türkiye \\ o.ormanli@iku.edu.tr \\ https://orcid.org/0000-0001-7812-7755
}

\section{ÖZ}

Teknoloji bağlamında tecrübe edilen her alan, farklı deneyimleri de beraberinde getirmektedir. Özellikle Web 2.0 ile birlikte ortaya çıkan en birincil problem, teknolojik tabanlı güvenlik açıkları ve 1-0'lardan oluşan ve geride bıraktığımız dijital izlerdir. $\mathrm{Bu}$ da insanları dijital gelecekte birçok sorun ile karşı karşıya bırakmaktadır. A $\breve{g}$ toplumunda sosyal bir komün içerisinde bilgi alışverişi yapilmaktadir. Sunulan sosyal medya tabanlı onlarca program ve uygulama gerçekten bedava mıdır, yoksa insanlar sosyal ağların birer dijital emekçisi midir soruları gündemi işgal etmektedir. Bu hizmetler karşılığında hiç şüphesiz onlarca veri, çeşitli veri tabanlarında algoritmalar marifetiyle özel hayatlara uzanacak boyutta analiz edilip tekrar onların lehine dönebilmektedir. Teknoloji ile birlikte artık dur durak bilmeyen dijitalleşme bütün hızıyla geleceğe doğru evrilmektedir. İnsanların tercihleri, özel hayatları, saplantıları, zayıf ve güçlü yanları; dijital bir "depo" veya bir “verihane" içerisinde A'dan Z'ye tutulmaktadır. Bu makalede, dijital toplumun geleceğinde bireyin karşılaşacağ 1 zorluklar, teknolojik gelişmelerin ortaya çıkardığı açıklar, karşı karşıya kalınacak problemler ve siber güvenlik meselesi eleştirel bir yaklaşımla nitel bir yöntemle ele alınacaktır.

Anahtar Kelimeler: Teknoloji, Dijital Toplum, Siber Güvenlik, Dijitalleşme, Sosyal Medya 


\title{
TECHNOLOGY AND CYBER SECURITY THE FUTURE OF DIGITAL SOCIETY
}

\begin{abstract}
Each area experienced in the context of technology brings different experiences. The main problem with the introduction of Web 2.0 is the technology-based security vulnerabilities and our digital traces comprising of 1-0s. This causes us to face many problems in the digital future. We exchange information in a social community within a network society. Are all the social media-based programs and applications offered for us really free? Or are we all digital labourers of social networks? In exchange of the services offered to us, huge amount of data, undoubtedly, are analzyed by algorithms in various databases and return back to us even to our private lives. Our digitalization story which is no longer stopping with technology is evolving towards the future with all speed. Our real life story, our preferences, our private life, our obsessions, our weaknesses and strength, namely everything from $\mathrm{A}$ to $\mathrm{Z}$ are recorded in a digital "Data House". In this article, The challenges the individuals face in the future of digital society, the deficits created by technological developments, the helplessness we will face and the issue of cyber security will be handled with a critical approach.
\end{abstract}

Keywords: Technology, Digital Society, Cyber Security, Digitalization, Social Media

\section{GİRIŞ}

Teknoloji, devamlı ilerleyen ve sürekli gelişen bir olgu olması sebebiyle hayatın geniş alanlarına nüfuz etmektedir. Burada genel itibariyle şu sorular sorulabilir. Teknolojik gelişmeler iyi midir yoksa kötü müdür? Teknolojinin, insanların kullanımına dâhil olduğu, ancak bireylerin idaresinde gelişmeyebilen kontrolsüz bir alanda ortaya çıkıp kontrol dışında gelişim gösteren bir araç olma ihtimali yüksektir.

Theodore John Kaczynski'nin (Unabomber) "Sanayi Toplumu ve Geleceği”" (Kaczynski, 2013) adlı manifestosunda ortaya koyduğu bazı fikirler doğru olabilir mi? Kaczynski'nin bu manifestosu teknoloji ve endüstriye dayalı sisteme karşı kaleme alınmış ve ABD' deki gazetelerde yayımlanmak zorunda kalınmıştır. Sanayi toplumunun ve gelişen teknolojinin sonuçları yirmi sene önceki öngörüler ile okunup yirmi birinci yüzyılın ilk çeyreğine endekslenebilir. Theodore John Kaczynski'nin çeşitli bombalı eylemleri kanunlar çerçevesinde kabul edilemez bir durum olarak ortaya konmuştur. Ancak manifestoda belirtilen fikirler bazı çıkarımlar yapılmasını da gerektirmektedir. Kaczynski'nin manifestosunda belirtmiş olduğu önemli alıntılar da bu çalışmanın sonunda yer alacaktır. 
Çalışmada dijital toplumun geleceği üstte belirtilen yaklaşımlarla birlikte, teknoloji ve siber güvenlik bağlamında irdelenecektir.

\section{DİJITAL İZLER VE ALGORITMA}

Toplumun yaygın olarak kullandığı yeni medya ve sosyal medya araçları "Google, Twitter, Facebook, Instagram ve LinkedIn" benzeri uygulamalar olarak ifade edilebilir. Bahsi geçen bu araçların kullanımları da ücretsiz olarak sunulmaktadır. Dolayısıyla bu uygulamaları ücretsiz bir şekilde sunan şirketler de içeriklerinden yayınladıkları reklamlar aracılığıyla kazanç elde etmektedir. Bu araçları kullanan kişilerin takipçileri, uygulama içerisinde yapılan aramaları, beğenileri, yorumları, paylaşımları ve çeşitli içerik hareketleri de reklam oluşturulma aşamasında önem kazanmaktadır. Bu eğilimlere göre reklam içerikleri düzenlenip kullanıcıların reklamlara muhatap olmaları sağlanmaktadır. Bu noktada "güvenlik, hesap ayarları, gizlilik" gibi önemli aşamalar da değer kazanmaktadır. Bu durumu araştırmacı fenomen bir Twitter kullanıcısı olan ayrıca bilim, teknoloji, evren, uzay, fizik yasaları, gezegen sistemleri ve daha birçok konuda bilgiler aktaran “@lagaribey”in 3-4 Kasım 2018 tarihlerinde yapmış olduğu ve 32 maddede belirtilen flood tweet paylaşımlarında da görebilmek mümkündür.

“@lagaribey” Twitter kullanıcısı ortaya çıkan çeşitli durumları aşağıdaki tweet paylaşımlarında şu şekilde özetlemektedir:

"Adam, mağazadan klzına gönderilen broşürler ve hediye kuponlartyla adeta deliye dönmüştü. Zira gelen şeyler hamilelikle ilgiliydi. Oysa kızı daha liseye gidiyordu. Değil hamile olmast, măgazanın bu ürünleriyle ilgilenmesi bile imkânsızdı. Soluğu doğruca mă̆azada aldı. Mă̆aza müdürünü bulup, "Kızımı hamileliğe mi teşvik ediyorsunuz, o daha liseye gidiyor, neyi amaçlyyorsunuz siz" diye bağırdı ve ortalı̆̆ birbirine katarak evine döndü. Fakat birkaç gün sonra aynı müdürü arayıp, "Kızım hamileymiş, size bir özür borçluyum” demek zorunda kalmıştı. Peki, ama mă̆aza, kızın sadece kendisinin bildiği bu mahrem bilgiye nasıl ulaşmıştı? Bu sorunun cevabı çoğu kişi tarafindan bilinmeyen, ancak büyük bir sektör haline gelmiş olan 'gözetleme ekonomisi'nde yatıyor. Biz buna dijital izler diyelim. Parmak izi gibi. Mağaza, müşteri profillerini çıkarmak için özel analizler yapıyordu. Bu analizlerden biri de hamilelik tahmin algoritmasiydl. Algoritma, hamile kadınların, özellikle hamileliğin ikinci üç ayından itibaren magnezyum ve çinko içerikli vitamin ürünlerini aldığını, kokusuz losyonlar tercih ettiğini belirlemişti. Bu bilgileri kredi kartı bilgileriyle eşleştiren algoritma, bir kadının hamile olup olmadı̆̆ın yüksek bir oranla belirleyebiliyordu. Kızın hamile olduğunu da bu şekilde belirlemişti. ABD'deki Target isimli bu mağaza 2013 'de hacklendi ve 110 milyon müşterisinin verisi çalındl." (https://twitter. com/lagaribey/status/1058818478101159938). 
Bir başka örnekte ise “@lagaribey” Twitter kullanıcısı şunları ifade etmektedir:

"Kapısına bırakılan satış broşüründeki notu gören Mike'ın canı oldukça sıkılmışt, çünkü üzerinde "Mike Seay, kızı trafik kazasinda öldü” yazıyordu. Kızı gerçekten de geçen yıl geçirdiği bir trafik kazası sonucu genç yaşta hayatını kaybetmişti. Ancak firma bunu nasıl bilebilirdi? Oysa ofis malzemeleri satan o firmaya sadece bir defa gitmiş ve yazıcısı için kă̆ıt almıştı. Firmayı arayıp şikâyet ettiğinde, yetkili durumu inkâr etti. Fakat olay medyaya taşınınca, firma; "Bizden kaynaklanmayan bir sebeple oluşan bu hatadan dolayı özür dileriz" demekle yetindi." (https://twitter.com/lagaribey/status/1058818478101159938).

“@lagaribey” ortaya çıkan geniş çaplı veri ve bilgi hırsızlığında büyük ölçekli uluslararası şirketlerin de büyük payı olduğunu belirtmektedir. Bir başka paylaşımı ise şu şekildedir:

"Acxiom, Epsilon, RapLeaf, Flurry, BlueKai. Bunlar çoğu kişinin adını duymadı̆̆ şirketlerdir. Yüz milyarlarca dolarlı gözetleme sektörünün arkasındaki veri simsarlığı da ortaya koymaktadır. Bu şirketlerin amacı verileri toplamak, analiz etmek ve reklamcılara ya da pazarlamacılara satmaktır. Bir kişiye ait ulaşabildikleri ne kadar veri varsa hepsine ulaşmayı kendilerine amaç edinmişlerdir. Bu verileri, kişilerin online aktivitelerinden bankalara, kredi kartı hareketlerinden kullandıkları mobil operatörlere veya üye olduklarl yerlere kadar pek çokyerden toplayabilmektedirler. Mesela bu firmalardan Acxiom'un arşivinde, bütün dünyadan 700 milyondan fazla kişinin bilgisi mevcut ve her kişiye 13 haneli bir kod atanmıs durumda. Bu kodlar, her biri farklı bir profil içeren 70 kümeden birine atanıyor ve kişi o profille tanımlanıyor. Misal, 56 no'lu kümedekiler; "3035 yaş aralı̆̆ında, üniversite mezunu, boşanmış, 1 ya da 2 çocuğu olan, orta düzey geliri olan, kirada oturan erkekler" gibi. Firma bu bilgileri olduğu gibi satabiliyor ya da kategoriyi daha da daraltmak için başka bir firmaya verebiliyor. Bu durumda diğer firma, aldiğı bilgilere ek olarak; "kamuda çalışanlar", "babast sağ olanlar", "şu lokasyonda oturanlar" ya da "alkole düşün olanlar" gibi daha da detaya inebiliyor. Bazı firmalarsa bu kümelerle ilgili çok daha derin detaylara ve özel bilgilere inebiliyor. Örneğin "kanser hastası olanlar", "HIV virüsü taşlyanlar", "X ameliyatı olanlar" ya da "cinsel saldırtya uğrayanlar" gibi. Büyük veri simsarlarından MEDBASE200 isimli şirket, bu bilgileri çok ucuz bir fiyata (ortalama 1.000 kişi için 79 dolar) isteyen ilaç firmalarına satıyor." (https://twitter.com/lagaribey/status/1058818478101159938).

Yukarıda belirtilen bu paylaşımlardan hareketle "gözetim toplumu" dolayısıyla "panoptikon" olgusuna değinmek gerekmektedir. Fransız düşünür Michel Foucault, insanların yönetilmesi ve yönlendirilmesi hususunda gözetim ve 
gözetim aygıtlarının çağdaş kurumlarda kolaylıkla kullanıldığını ifade etmektedir. Foucault, "Ĕger bilgiye erişimi belirli sayıda insanla sinırlı tutmak isterseniz, bu şekilde bilgiyi ürkütücü bir şekle sokarsınız" demektedir. Foucault ayrıca İngiliz filozof Jeremy Bentham'ın tasarladığ hapishane modelinden hareketle fikirlerini oluşturmuş ve temellendirmiştir. Foucault'nun "panoptikon" diye tanımladığı tasarıya göre az sayıda gardiyandan oluşan bir denetim evi ile çok sayıda mahkum izlenebilmektedir (https://www.wannart.com).

"Panoptikon" olgusuyla ortaya çıan bu durum 4 Aralık 2011 tarihinde yayınlanmaya başlayan İngiliz televizyon dizisi "Black Mirror" ile değerlendirilebilir veya düşünsel olarak eşlenebilir. Bu durumu bir örnekle açılamak gerekir ise Çin'de yaşanan yoğun bir "gözetim toplumu" konuyu kavramak açısından önemli olabilir. Başka bir ifadeyle bir "Black Mirror" distopyası olarak Çin devleti örnek olarak verilebilir. Çin, bu açıdan bakıldığında "dijital toplum" için önemli bir örnek teşkil etmektedir. Çin devleti, gelişmiş yüz tanıma teknolojileri, yapay zekâ tabanlı veri analiz sistemleri ile bir milyar beş yüz bine yakın vatandaşını takip etmektedir. Yine bir örnekle açıklamak gerekirse Çin vatandaşları toplumsal kıstaslara göre kredilendirilmekte ve dolayısıyla düşük kredi puanlı vatandaşlarını ulaşım, barınma, çalışma ve çeşitli temel insan haklarından yoksun bırakan bir "sosyal kredilendirme sistemi"ni uygulamaktadır (http://www.ozgurkurtulus.com.tr). Bu açıdan bakıldığında Çin'de bir "gözetim toplumu hayatı" yaşandığı söylenebilir. Öte yandan gözetlemeyle ilintili olarak ortaya çıan bu durumlar ilk kez 21 Ekim 2016'da yayınlanan "Black Mirror" dizisinin "Nosedive" (Dibe Vuruş) bölümünü hatırlatmaktadır. (https://www. pazarlamasyon.com)

Yukarıda verilen örneklere bakıldığı zaman bedava sunulan çoğu hizmetin arka planında kullanıcıların bilgilerinin, eğilimlerinin, tutumlarının ve internet teknolojileri aracılığıyla yaptıkları aramalarının hizmet sunan şirketler tarafından üçüncü şahıslara sunulduğu görülmektedir. Michihiro Matsumoto'nun 1988 yılında yayımlanan The Unspoken Wayitabında da geçen bir Japon atasözü de "Tada yori takai mono wa nai", "Hiçbir şey bedava verilenden daha pahalı değildir" demektedir (http://www.notableandquotable.blogspot.com). Bu Japon atasözü günümüz internet teknolojilerine ve yaşanılan dijital toplumun içeriğine de uygun düşmektedir.

Örnek vermek gerekirse, “@lagaribey” adlı Twitter kullanıcısının ifade ettiği "veri simsarlarl"nın toplamış olduğu verilerin önemli bir kısmı "bedava" diye düşünülüp akıllı telefon veya tabletlere kurulan uygulamalardan oluşmaktadır. Dolayısıyla bu ve benzeri programlar kişisel araçlara indirilirken bilinmeyen veya bakılmayan izinleri de beraberinde getirmekte ve kullanıcının kendi isteğiyle 
ne yapılacağını bilmediği bilgilerini hizmeti sunan şirketlere kendi rızasıyla vermiş olduğu görülmektedir. Yine “@lagaribey” adlı Twitter hesabının zincir tweetlerine bakıldığında bu durumla karşılaşılmakta ve yukarıda öne sürülen savlar da desteklenmektedir. “@lagaribey” Twitter hesabının paylaşımlarından hareketle aşağıdaki örnek, yukarıda belirtilen bu durumu da ortaya koymaktadır:

“Örneğin Angry Birds, Candy Crush, Fruit Ninja gibi ücretsiz popüler oyunlar neden sizden lokasyona ve temel bilgilere erişim izni ister? Mutlaka başınıza gelmiştir. İndirdiğiniz bir uygulama, içeriğinden bağımsız garip izinler ister. Siz de indirmek için bunlara onay verirsiniz. Milyonlarca kişinin oynadığı bu oyunlarl yazan firmalar nasil para kazaniyor sanıyorsunuz? Borsadan mı? Marka değerinden mi? Mükemmel girişimcilik hikâyelerinden mi? Ya da şöyle diyelim; neden Google, yıllarca üzerinde çalıştı̆̆ onlarca uygulamayı hiç para almadan herkese bedava dağıttyor? Peki ya Twitter, Facebook, Instagram, Snapchat ve diğer uygulamalar?"

Diğer yandan Facebook sosyal ağı birçok şirketin popüler uygulamalarını da satın almıştır (https://www.onedio.com). Burada şu soru sorulabilir, "Facebook şirketi bu uygulamaları bir kâr amacıyla mı satın almaktadır, yoksa bünyesinde bulunan verilerin çokluğu dolayısıyla mı bu satın almaları gerçekleştirmektedir?"

Bu örnekten hareketle akıllı telefonlardaki parmak izi okuma, yüz tanıma ve sesli komut teknolojileri de bahsi geçen datalar ile eşleştirilip kişiye özel daha tutarlı veriler oluşturulabilir. Örneğin Apple firması bir dönem cihazlarında parmak izi okuyucusunu kaldırıp Face ID'ye geçmiştir. Sonrasında ise yeni cihazlarında tekrar Touch ID özelliğini ana ekranda kullanmaya uygun şekle getirdiğini açıklamıştır (http://www.milliyet.com.tr). Dolayısıyla güvenlik açısından bakıldığında da bu ve benzeri büyük ölçekli şirketler cihazları ve uygulamaları sayesinde hem parmak izi hem de yüz (suret) bilgilerini toplanmaya devam etmektedirler.

Buraya kadar aktarılan ve sunulan bilgiler dijitalleşen toplum hayatına eklemlenen süreçler silsilesinden ileri gelmektedir. İnternete bağlı olan her cihaz izlenebilmekte ve bütün hareketler takip edilebilmektedir. Ortaya çıkan bu durumu “@lagaribey” Twitter hesabı şu şekilde ifade etmektedir:

"Facebook kullanmiyorum, kapattım ya da gizlilik ayarlarımı en üst düzeye getirdim diyerek kendinizi rahatlatan bir açılama yapabilirsiniz, fakat bilmediğiniz bir şey var. Facebook, hesabinız olmasa bile reklam ortaklar sayesinde sizi izleyebiliyor. Girdiğiniz bir sitede, Facebook'un o meşhur "beğen" tuşunun olması yeterli. Hesabınızın olup olmaması, o tuşa basıp basmamanı önemli değil. Kayıt altındasınız. Hatta o sitede "beğen" butonu da olmayabilir. 
Veri simsarları vasıtasıyla neler yaptığınızı yine takip ediyorlar. Facebook, yaklaşık 10 beğeni veya paylaşımdan sonra sizi çevrenizdeki insanlardan daha iyi taniyabiliyor. Sadece Facebook değil elbette. Tüm internet bu şekilde işliyor. Örneğin bir ay önce bir uçak bileti sorguladınız. Aradan çok fazla zaman geçmeden internette herhangi bir haber sitesine girdiniz. Haber okurken bir ay evvel sorgulama yaptı̆̆ınız seferler reklam kutucuğunda yer alır. Bu bir tesadüften ibaret değildir.

Diğer yandan benzer şekilde Google 'ın Gmail 'ini de kullanmiyorum diyebilirsiniz, ancak yine bir şey fark etmiyor. Ĕger Gmail hesabı olan birine mail attlysanız, bu Google'ın sizin hesabınızı mercek altına alması için yeterli. Çünkü Gmail lisans anlaşmasina göre Google'ın buna hakkl var. Google hem kendi ürünleri (Gmail, Google Docs, Google Drive, Haritalar) hem satın aldiğ firmalar (Youtube gibi) hem de veri simsarlarl vasitaslyla bizi bizden daha iyi taniyor. Google'ın CEO'su vaktinde şöyle demişti: 'Ş̧ an nerede olduğunuzu ve az çok ne düşündüğ̈nüzü biliyoruz.'

Google ve Facebook, bu sektörün en büyük oyuncularl, fakat bizi gözetleyerek verilerimizi alan, analiz ederek ya da etmeyerek satan Twitter, Linkedln, Pinterest, Snapchat ve Foursquare gibi irili ufakl binlerce firma daha var. Bu firmalara, "konum" bilgisine erişmek için izin vermek bile çok şey ifade ediyor. Çünkü konum bilgisi sayesinde sadece bugün nerede olduğunuzu bilmiyorlar, bir ay önce nerede olduğunuzu da biliyorlar, daha da önemlisi yarın nerede olacağınızı da kestirebiliyor, hatta yüzde 99 oranla bunu biliyorlar.”

Princeton Üniversitesi'nin yürüttüğü bir araştırma da yukarıda aktarılan bu durumu ortaya koymaktadır. Araştırma 400'den fazla popüler internet sitesinin kullanıcılarının web sitelerinde yaptıkları tıklamaları, fare hareketlerini ve sayfaları kaydırma davranışlarını gözlemleyebildiğini ve çevrim içi hareketlerini takip edebildiğini öne sürmektedir (https://www.internethaber.com).

Akıllı telefonların mikrofon izni verilmeden çalışmayan çoğu uygulaması da ortam dinlemelerine açık olabilmektedir. Öne sürülen bazı savlarda da reklam veren şirketlerin ortam dinlemesine endeksli reklam stratejileri yürüttüğü savunulmaktadır ve konuşulan herhangi bir şeyin kısa mesaj (SMS) veya uygulamalar içerisinde iletiler aracılığıyla telefonlara iletilmesi de uzun süre tartışılan konuların başında yer almıştır (https://www.bbc.com). Mikrofon izni verildikten sonra telefonun tuş kilidi kapalı olsa da dinleme yapılabilmektedir (https://www.medium.com). Bu aktarımlardan hareketle, "Bizler sanal dünyanın (dijital toplumun) gerçek ürünleriyiz” düşüncesi de ortaya çıkabilmektedir. 
Teknoloji ile birlikte her an gelişen ve değişen, durmaksızın yeniden örülen dijitalleşme serüveni bütün hızıyla geleceğe doğru evrimle sürecinde ilerlemektedir. Sanal dünyanın ötesinde bireylerin gerçek yaşam hikâyeleri, tercihleri, özel hayatları, saplantıları, zayıf ve güçlü yanları dijital bir "verihane", bir başka ifadeyle "dijital depo" içerisinde baştan sona tutulmaktadır. Tarihçi ve yazar Yuval Noah Harari de, "Bilgiye sahip olanın dünyayı da yönetebileceğini" söylemektedir (https://www.marketingturkiye.com.tr). Geleceğin dijital dünyasında dijital verilerin neredeyse tamamına sahip olabilen devletler veya bağımsız çeşitli uluslararası ölçekteki şirketler "dijital imparatorluklar"1 da meydana getirebilirler. 21. yüzyıl (dijitalleşme ve piyasa) ekonomisini tekstil, araçlar ve silahların değil; bedenler, beyinler ve zihinlerin oluşturabileceği düşünülmektedir. Dolayısıyla Harari'nin deyimiyle ortaya yeni bir ideoloji de çıkmaktadır. Bu ideolojiye "Dataizm" denilmektedir (https://www.dunyahalleri. com).

"Dataizm", bir inanç sisteminden farklı olarak evrenin bilgi akışından meydana gelmektedir. Yeryüzünde meydana gelen tüm olayların ve gelişmelerin bilgiler ışığında çözümlenebilir olduğunu ifade eden kapsayıcı bir teoridir. Dataizm, ilerleyen süreçlerde bilginin veya bilgiye sahip olanın en büyük güç haline geleceğini, bilgiyi elinde bulunduran tarafların diğerlerinden daha fazla etkiye sahip olacağını ve bilgiye ulaşmanın bir güç göstergesi olduğunu ifade eden bir yaklaşım olarak da ortaya çıkmaktadır (https://www.tozlumikrofon.com).

Günümüzde dünyanın en büyük ülkelerini sosyal ağlar ve internet kullanıcıları oluşturmaktadır denilebilir. 2018 yılı 2 . çeyrek araştırma verilerine göre dünyadaki internet ve sosyal medya kullanımı istatistikleri de bunu göstermektedir. "We Are Social 2018" raporuna göre "Dünya İnternet, Sosyal Medya ve Mobil Kullanicı İstatistikleri" aşağıdaki gibidir:

- Dünya nüfusunun \%54 'ünü oluşturan 4.08 milyar kişi “İnternet Kullanıcısı”(2017'de bu oran 3.81 milyar kişi ile \%51'di).

- Dünya nüfusunun \%43'ünü oluşturan 3.29 milyar kişi "Sosyal Medya Kullanicısı"-(2017'de bu oran 3.02 milyar kişi ile \%37'ydi).

- Dünyanüfusunun\%66'sinioluşturan 5.06milyarkişi “MobilKullanıcısı”(2017'de bu oran 5.05 milyar kişi ile \%66'ydl).

- Dünya nüfusunun \%41'ini oluşturan 3.08 milyar kişi “Mobil Sosyal Medya Kullanicısı"-(2017'de bu oran 2.78 milyar kişi ile \%34'tü). (https://www. brandingturkiye.com).

$\mathrm{Bu}$ veriler doğrultusunda dijital bir toplumun dijital bir bilince sahip olması, dolayısıyla siber güvenlik alanlarında çeşitli okumalar ve araştırmalar yapması, kullandığı araçlar ve bilinçli bir kullanıcı için önemli bir gereklilik olarak 
düşünülebilir. Theodore John Kaczynski'nin (Unabomber) "Sanayi Toplumu ve Geleceği" adlı manifestosunda ortaya koyduğu bazı fikirler 21. yüzyılın teknolojik gelişimine ve dijital toplumun geleceğine dönük önemli bilgiler içermektedir. Yukarıda da belirtildiği üzere bu kısımda Theodore J. Kaczynski’nin şiddete dayalı eylemleri onaylanmamaktadır. Bu açıdan Kaczynski'nin manifestosunda ortaya koyduğu fikirler bağlamında bazı çıkarımlar yapılmaktadır:

"Kişiler, seçkinler (teknolojiyi elinde tutanlar) ile genel halk (teknolojik olarak gücün dayatıldı̆̆ı) arasındaki çatı̧̧ma dışındaki diğer toplumsal çatışmaları teşvik etmeden önce iki kez düşünmelidirler. Bir kere, diğer çatışmalar ilgiyi önemli çatışmalardan (güçlü seçkinlerle sıradan halk arasındaki, teknoloji ile doğa arasındaki) saptırır; diğer taraftan da diğer çatışmalar teknolojikleşmeyi teşvik eder; çünkü iki taraf da, rakibine karşı avantajlı olmak için teknolojik gü̧ kullanmak ister. Bu, ülkeler arsındaki rekabetlerde açıkça görülür.

Genel olarak, "modern insanın” doğaüstündeki muazzam gücü bireyler ya da küçük gruplar tarafindan değil, büyük kuruluşlar tarafindan kullanılmaktadır. Ortalama modern BIREY teknolojiden bir dereceye kadar yararlanabilir. Ancak sistemin denetimi ve kontrolü altında ve ancak dar sinırlar içinde bu hak ona verilir (Her şey için izin gereklidir ve bu izin beraberinde kural ve düzenlemeleri getirir). Birey sadece sistemin ona vermeyi uygun gördügü bazı teknolojik güçlere sahiptir. Doğaüstündeki KişiSEL gücü önemsizdir.

Bugün, teknolojik açıdan ilerlemiş topraklarda, insanlar coğrafi, dini ve politik farkllliklara rağmen birbirlerine çok benzer hayat sürerler. Chicago'daki Hristiyan bir banka memurunun, Tokyo'daki Budist bir banka memurunun ve Moskova'daki komünist bir banka memurunun hayatlarl birbirlerine, binlerce yll önce yaşamış basit bir adamın hayatından çok daha benzerdir. Bu benzerlikler, ortak teknolojinin sonucudur.

Teknoloji, insanları dönüşü olmayan bir yola sokmuştur. Gelişen teknoloji ve endüstriyel toplumun insanliğa; ekonomik, çevresel, sosyal ve psikolojik olarak problemler getirdi. Aşırı toplumsallaşma, insanlığın bireye yaptı̆̆ en büyük zulümdür. Gelecekte toplumsal sistemler, insanlarn ihtiyaçlarına göre düzenlenmeyecek, bunun yerine insanlar sistemin ihtiyaçlarına uydurulacaktır. Ĕglence, modern insana önemli bir kaçış aracı sağlar. İnsan televizyona, videoya vs. gömülmüş̧ken, stresi, endişeyi, hayal kırlklığını ve tatminsizliğini unutabilir..." (Kaczynski, 2013).

Diğer yandan teknoloji konusunda eleştirel bir tutum ortaya koyan Martin Heidegger, herkesin teknolojiye esir ve mahkum olduğunu ifade etmektedir. 
$\mathrm{Bu}$ durumun asıl sebebinin ise teknoloji ile gerçekçi bir ilişkinin bilinmiyor oluşuna bağlamaktadır. Heidegger'e göre teknoloji ile teknolojinin özü aynı şeyi ifade etmemektedir. Heidegger ayrıca modern teknolojide saklı olan gücün insanın var olanla ilişkisini belirlediğini, fakat teknolojik ilerlemenin gittikçe daha da hızlanacağını ve hiçbir şekilde durdurulamayacağını, dolayısıyla insanın varoluşununun bütün alanlarına ulaştıkça daha sıkı biçimde teknolojinin güçleriyle kuşatılacağını savunmaktadır (Aydoğan 2017: 79-165).

\section{SONUÇ}

Teknoloji ve dijitalleşme günlük hayata entegre olup yaygınlaştıkça, getirdiği avantajlara karşılık birçok sorunu da beraberinde getirmektedir. Web 2.0 ile birlikte ortaya çıkan en birincil problemlerden biri de teknolojik tabanlı güvenlik açıklarıdır. Ayrıca 0-1'lerden oluşan ve bilmeden veya bilerek geride bırakılan dijital izler de bu konuya dahil edilebilir. Bütün bunlar kullanıcıları dijital gelecekte birçok sorun ile karşı karşıya bırakmaktadır. Daha önce de vurgulandığı üzere, a ̆ toplumunda birbirimize çevrimiçi ortamlarda bilgi alışverişi yapılmaktadır. $\mathrm{Bu}$ bağlamda dijital dünyanın dijital emekçisi olan kullanıcılar bedava sunulan bu uygulamaların birer gönüllü mavi yakalı konumundadırlar.

İnsan ve dünya teknoloji ile beraber yeni bir boyutta ve yeni bir evrende devaml surette yeniden şekillenmektedir. Yukarıdaki kısımlarda da belirtildiği üzere bu konularla ilintili olarak bilinç düzeyi uyanık ve yüksek dijitalleşen dünyanın bilinçli bireyleri meydana getirilebilir. Dijital bilinç, kodlama eğitimleri, algoritma bilgileri ve başlangıç seviyesinde siber güvenlik konuları ile teknolojinin her safhasından alıntılar yapılarak bu safhalardan geçilmesi önemli bir aşama olmaktadır. Dolayısıyla bilinç düzeyi artan bireylerin ve toplumların gelişen ve oluşan yeni şartlara da hızlıca adapte olabilmeleri sağlanabilir.

\section{KAYNAKÇA}

Goodman, Marc. Geleceğin Suçları, Dijital Dünyanın Karanlık Yüzü, İstanbul: Timaş Yayınlarl, 2016.

Heidegger, Martin. Heidegger: Teknoloji ve İnsanlığın Geleceği, (der. çev. Ahmet Aydoğan), Istanbul: Say Yayınları, 2017.

Kaczynski, Theodore John. Sanayi Toplumu ve Geleceği, The Unabomber Manifesto: Industrial Society and Its Future, Istanbul: Çeviren, Kolektif Kaos Yayınlarl, İstanbul, 2013.

Schneier, Bruce. Data and Goliath, The Hidden Battles to Collect Your Data and Control Your World, New York: W. W. Norton \& Company, 2015.

Scott, James, (2017), Dragnet Surveillance Nation: How Data Brokers Sold Out America, California: CreateSpace Independent Publishing Platform, 2017. 


\section{INTERNET KAYNAKLARI}

https://www.bbc.com/turkce/haberler/2016/03/160302_casus_akilli_telefon

https://www.brandingturkiye.com/dunyadaki-en-populer-sosyal-aglar/

https://www.dunyahalleri.com/21-yuzyil-ekonomisinin-ana-urunleri-tekstilarac-ve-silahlar-degil-bedenler-beyinler-ve-zihinler-olacak/

https://www.internethaber.com/internet-ortaminda-fare-hareketleri-bileizleniyor-1826123h.htm

https://www.marketingturkiye.com.tr/haberler/sapiensin-yazari-harari-veriyesahip-olan-insanligin-kaderini-belirleyecek/

https://medium.com/@halidox/ortam-dinlemesiyle-gelen-reklamlarla63ec0832e1

http://www.milliyet.com.tr/iphone-da-parmak-izi-okuyucu-geri-applehaber-2867417/

http://www.notableandquotable.blogspot.com/2011/01/japanese-wisdom-onhidden-danger-of.html

https://onedio.com/haber/hizli-yukselis-karlilik-ve-skandallar-facebook-unyakin-tarihine-bakis-866041

http://www.ozgurkurtulus.com.tr/yil-2018-gozetim-toplumu-yuklendi/

https://www.pazarlamasyon.com/cinin-distopik-sosyal-kredi-sistemi-kismenhayata-gecti/

https://www.tozlumikrofon.com/dataizm-nedir/

https://twitter.com/lagaribey

https://www.wannart.com/denetim-altinda-tutulan-insan-ve-panoptikon-teorisi/ 



\section{İSTANBUL AYDIN ÜNIVERSITESİ DERGİSI Yazar Kılavuzu}

Aşağıda belirtilen yayın ilkeleri ve yazım kurallarına uygun olarak hazırlanmış, yazılar, e-posta (iaud@aydin.edu.tr) yoluyla aşağıdaki adreslere gönderilebilir. Ön inceleme ve hakem değerlendirmesi doğrultusunda geliştirilmek ve/veya düzeltilmek üzere yazarlarına geri gönderilen yazılar, gerekli düzeltmeler yapılarak en geç, bir ay içinde tekrar dergiye ulaştırılır. Yapılan ön incelemede yazım kurallarına uyulmadığı tespit edilen makaleler düzeltilmesi için yazarına iade edilir ve yayım programına alınmaz.

\section{Yayın İlkeleri}

İstanbul Aydın Üniversitesi Dergisi (İAÜD); medya çalışmaları, iktisat ve işletme çalışmaları, ekonomi, mimarlık, iletişim çalışmaları, reklamcılık, halkla ilişkiler, sosyal bilimler, sağlık iletişimi, sosyoloji, eğitim bilimleri, insan kaynakları yönetimi, televizyon ve sinema, hukuk, Türk dili ve edebiyatı, iç mimarlık, maliye, sosyal politika ve çalışma ilişkileri, grafik tasarımı, siyaset bilimi ve uluslararası ilişkiler, davranış bilimleri, tarih, sanat tarihi, arkeoloji, uzaktan eğitim, yabancı diller ve edebiyatları, dil bilim ve bunun gibi sosyal bilimlerdeki ilgili alanlarında bilimsel eserleri yayınlar.

İstanbul Aydın Üniversitesi Dergisi senede 4 defa yayınlanan hakemli bir dergidir. Orijinal teorik ve/veya deneysel çalışma ve sabit referans değerleri ile ilgili öğretici açıklamanın bulunduğu makaleler kabul edilir.

İstanbul Aydın Üniversitesi Dergisi yayın kurulu, uluslararası uzmanların değerlendirmesiyle makalelerin kabul edilmesi veya edilmemesinde yetkilidir.

\section{GENEL KURALLAR}

1. Dergide yayımlanan yazı ve makalelerde kullanılacak dil Türkçe ve İngilizcedir.

2. Çalışmayı destekleyen bir kurum varsa, makale başlığının son kelimesi üzerine (*) konularak, aynı sayfada dipnot olarak destek veren kurum bilgileri belirtilmelidir.

3. Gönderilen yazılar kaynakça ve ekler dahil $\mathbf{1 2 . 0 0 0}$ kelimeyi aşmamalıdır.

4. Makaleler APA referans sistemine (APA 6.0) göre düzenlenmelidir. Lütfen metin içinde verilen referansların kaynakçada olmasına özen gösteriniz.

\section{Yazım Kuralları}

\section{- Sayfa Düzeni}

Üst $3,5 \mathrm{~cm}$, alt $2,5 \mathrm{~cm}$, sol kenar $2,5 \mathrm{~cm}$, sağ $2 \mathrm{~cm}$ boşluk bırakılacak şekilde tüm metin alanı $170 \mathrm{~mm}$ X $240 \mathrm{~mm}$ şeklinde olmalıdır. 


\section{- $\quad$ Yazı Türü}

Times New Roman yazı karakteri kullanılmalıdır. Türkçe “Öz” İngilizce "Abstract" bölümleri 11 punto, ana metin 11 punto, yararlanılan kaynaklar bölümü ise 1 punto olmalı; metin, Türkçe-İngilizce özet ve yararlanılan kaynaklar iki yöne yaslı olarak hizalanmalıdır. Metin tek satır aralığı kullanılarak yazılmalı, paragraflar arası 1 satır boşluk bırakılmalıdır.

\section{- Başlıklar}

Makale ana başlık ve alt başliklardan oluşacak şekilde düzenlenmelidir.

\section{- $\quad$ Ana Başlık}

Times New Roman karakterinde, büyük harfler kullanılarak, kalın, 14 punto şeklinde Microsoft Word formatında olmalıdır. Yazar ismi, kısaltmaları, yazar ORCID numarası ve e-posta adresleri başlıktan sonra iki satır boşluk bırakacak şekilde yazılmalı ve yazar ismi küçük, soyadı büyük olacak şekilde 11 punto yazı karakterinde yazılmalıdır.

\section{- $\quad \ddot{O} z$}

300 kelimeyi geçmemeli ve "ÖZ" kalın, 11 punto olmalı, özet metni 11 punto olarak tüm metin Times New Roman yazı stilinde iki yana yaslı ve tek paragraf şeklinde Microsoft Word formatında yazılmalıdır. Anahtar kelimeler italik, kalın yazı tipinde ve 11 punto olmalıdır. Makaleye uygun en az üç en fazla beş anahtar kelimenin ilk harfleri büyük diğer harfleri küçük olacak şekilde yazılmalıdır. “ÖZ”de makalenin konusu, araştırma yöntemi ve sonucuyla ilgili kısa bilgiler verilmelidir.

\section{- $\quad$ Abstract}

Abstract ana başlık türkçe anahtar kelimelerden sonra iki satır boşluk bırakılarak yazılmalıdır. Times New Roman karakterinde, büyük harfler kullanılarak, kalın, 11 punto, iki yana yaslı ve tek paragraf şeklinde Microsoft Word formatında olmalıdır. 600 kelimeyi geçmemeli ve "ABSTRACT" kalın, 11 punto olmalı; tüm metin Times New Roman yazı stilinde Microsoft Word formatında yazılmalıdır. Abstract'taki anahtar kelimeler (keywords) italik, kalın yazı tipinde ve 11 punto olmalıdır. Makaleye uygun en az üç en fazla beş anahtar kelimenin(keywords) ilk harfleri büyük diğer harfleri küçük olacak şekilde yazılmalıdır. "ABSTRACT”ta makalenin konusu, araştırma yöntemi ve sonucuyla ilgili kısa bilgiler verilmelidir.

\section{- Bölümler}

Makalenin içeriğine göre oluşturulan bölüm alt başlıkları (GİRIŞ, KAVRAMSAL ÇERÇEVE, LITTERATÜR TARAMASI, ARAŞTIRMA METODOLOJISİ, BULGULAR, SONUÇ, ...gibi) hepsi büyük harf olacak biçimde, 11 punto ve kalın (bold) olmalıdır ve numaralandırma kullanılmadan yazılmalıdır. 
- $\quad$ Ana Metin

Alt başlıklar 11 punto, kalın ve büyük harf kullanılarak yazılmalı ve metin kısmı 11 punto, Times New roman yazı stilinde Microsoft Word formatında olmalidir. Makaleler tek sütun, iki yana yaslı olacak şekilde ve paragraf aralarında tek aralık olacak şekilde yazılmalıdır. İlk bölümün alt başlığı anahtar kelimelerden sonra bir satır boşluk bırakarak başlamalı ve bunu takip eden metin paragraflarında boşluk olmamalıdır. Makale Uzunluğu şekiller ve figürler ile birlikte 20 sayfayı geçmemelidir.

\section{- Tablo, Şekil, Grafik ve Resimler}

Metinde kullanılan tablo, şekil, grafik ve resimler yazar(lar) tarafindan özgün olarak oluşturulmamış ise "kaynak" gösterilerek metin içinde kullanılabilir. Tablo, şekil, grafik ve resimler metin kısmına uyacak şekilde yerleştirilmeli ve başlıkları 11 punto ve ortalanarak yazılmalıdır. Metin içinde kullanılan tablo ve grafikler Tablo 1., Tablo 2./ Grafik 1., Grafik 2. ... vb gibi siralanmalıdır. Tablo numaraları ve başlıklar tablodan önce olacak şekilde yazılmalıdır. Şekil, grafik ve resimlerin numaraları ve başlıkları kendinden(şekil, grafik ve resim) sonra altta olacak şekilde Şekil 1., Şekil 2./ Resim 1., Resim 2. ... vb gibi sıralanarak yazılmalıdır. Tablo, şekil, grafik ve resim başlıklarında kullanılan kelimelerin ilk harfleri büyük diğerleri küçük olacak şekilde oluşturulmalıdır.

\section{- Sonuç}

Başlık kalın, 11 punto, büyük harflerle ve metin kısmı da 11 punto Times New Roman yazı stilinde Microsoft Word formatında yazılmalıdır.

\section{- Makale içi referans gösterimi}

Makale içinde referans gösterimi APA (en son sürüm) kurallarına uygun olacak şekilde düzenlenmelidir.

APA referans kuralları için bakınız: https://www.citefast.com/styleguide. php?style $=$ APA\&sec $=$ form

Tek yazarl1 kaynaklara referans: (Atılgan, 2015: 28), (At1lgan, 2015: 28-32)

İki yazarlı kaynaklara referans: (Atılgan \& Demir, 2015: 28), (At1lgan \& Demir, 2015: 28-32)

Beş yazarlı kaynaklara ilk kez referans yapıldığında: (Atılgan, Demir, Çelik, Savaş \& Y1ldırım, 2015: 28)

Beş yazarlı kaynaklara ikinci kez veya daha fazla kez referans yapıldığında: (At1lgan vd., 2015: 28)

Beşten fazla yazarlı kaynaklara ilk kez referans yapıldığında: ( Atılgan, Demir, Çelik, Savaş, Yıldırım....Işık, 2015: 28) 
Beşten fazla yazarlı kaynaklara ikinci kez veya daha fazla kez referans yapıldığında: (Atılgan vd., 2015: 28)

İnternetten referans yapıldığında: (Mills, 2012)

\section{- Kaynakça}

Makalede yararlanılan kaynaklar APA (en son sürüm) kurallarına uygun olacak şekilde düzenlenmelidir. APA kaynak gösterimi için bakınız:

https://www.citefast.com/styleguide.php?style=APA\&sec $=$ form

Kaynakça başlığı 11 punto, kalın; kaynaklar ise aşağıda gösterilen biçimde alfabetik, numarasız yazılmalıdır. Ayrıca eser ismi(referans alınan kaynak) italik olmalıdır.

\section{Tek yazarlı kitap}

Tuncer, D. (1992). Dağıtım Kanalları Sistemi. Ankara: Gazi Yayınları.

\section{İki yazarlı kitap}

Turgut, M. F. \& Y. Baykul. (1992). Ölçekleme Teknikleri. Ankara: ÖSYM Yayınları.

\section{Editörlü kitap}

Theberge, J. (Ed.). (1968). Economics of Trade and Development. New York: John Wiley.

\section{Çeviri kitap}

Morgan, L.H. (2015). Eski Toplum. (Oskay,Ü. Çev.), İstanbul: İnkılap Yayınevi.

\section{Kitap bölümü}

Ünlüer, A.O. (1988). Boş Zamanı Değerlendirme Açısından Kitle İletişim Araçlarının Ülkemizde Durumu. Demiray, U. (Ed.). Kitle İletişim Araçları ve Boş Zaman.(ss.71-113). Eskişehir: Anadolu Üniversitesi Eğitim Teknolojisi ve Yaygın Eğitim Vakfi.

\section{Basılı dergi}

Engin, B. H. (2016). Markalaşma Kavramı Çerçevesinde Marka Ederi. Öneri Dergisi. 12 (46): 277-294.

\section{Elektronik dergi}

Yengin, D. \& Algül, A. (2018). Küreselleşme Bağlamında Sanal Gerçeklik Kullanım1. Turkish Online Journal of Design, Art and Communication-TOJDAC. 10 (2): 155-126. doi: 10.7456/10902100. 


\section{Basılı Gazete}

Kumcu. E. (2006, 11 Aralık). Büyüme yavaşlama sinyali veriyor. Hürriyet Gazetesi. s.9.

\section{Elektronik Gazete}

Mills, S. (2012, 16 Ekim). How Twitter is winning the 2012 US election. The Guardian. https://www.theguardian.com/commentisfree/2012/oct/16/twitterwinning-2012-us-election (Erişim tarihi: 10 Temmuz 2018).

\section{Tez}

Algül, N. (2006). Sanat Tarihinde Mahmut Akok. Marmara Üniversitesi Türkiyat Araştırmaları Enstitüsü Türk Sanatı Anabilim Dalı Yayınlanmamış Doktora Tezi, İstanbul.

\section{Web sayfası}

Yavuz, E. (2018, 7 Kasım). Zaman ve İnsan Üzerine. https://dusunbil.com/ zaman-ve-insan-uzerine. adresinden alındı. (Erişim tarihi: 10 Temmuz 2018).

\section{Rapor}

Taymaz, E. (2018). Dijital Teknolojiler ve Ekonomik Büyüme Raporu. (TÜSIAD-T/2018,10-600).

\section{Elektronik Rapor}

Taymaz, E. (2018). Dijital Teknolojiler ve Ekonomik Büyüme Raporu. (TÜSIAD-T/2018,10-600). https://www.tusiad.org/tr/yayinlar/raporlar/ item/10130-dijital-teknolojiler-ve-ekonomik-buyume-raporu. (Erişim tarihi: 10 Temmuz 2018).

\section{İletişim Bilgileri: \\ ISTANBUL AYDIN ÜNIVERSITESİ DERGISİ Yayın Koordinatörlüğü, Doç. Dr. Deniz YENĞíN}

- Makaleler elektronik ortamda İstanbul Aydın Üniversitesi Dergisi'nin aşağıdaki e-posta adresine gönderilmelidir.

- İstanbul Aydın Üniversitesi, İletişim Fakültesi, Beşyol Mahallesi, İnönü Caddesi, No: 38

Sefaköy, Küçükçekmece/İstanbul

Tel: (212) 4441428

Web: http://iaud.aydin.edu.tr

E-mail: denizyengin@aydin.edu.tr 


\section{JOURNAL OF ISTANBUL AYDIN UNIVERSITY}

\section{Author's Guide}

Author's may send their articles which are prepared in accordance with the below stated publishing and editorial principles, together with the "article presentation form" via e-mail to the provided addresses.

Providing the permissions of the authors (the main author or the rightful publishing house) is obligatory for the translated texts and articles as well.

The articles which are sent to their authors for further improvement and/or proofreading following the preliminary reviews and referee evaluations, should be edited accordingly and delivered back to the journal in one month at the latest.

On the other hand, the articles which are found to be conflicting with this guideline, will be returned to their authors for further proofreading and will not be issued.

\section{Publishing Principles}

Istanbul Aydin University Journal (IAUD) publishes works from a wide range of fields including but not limited to food and food technologies, architecture, interior architecture, industry and industrial optimization, textile and textile applications, electronics, image processing, information theory, electronic systems, power electronics, control theory, embedded systems, robotics, modeling, system design, multidisciplinary engineering, computer engineering, optical engineering, materials science, semi-material, heat and mass transfer; kinematic, dynamic, thermodynamic energy and its applications, renewable energy, environmental effects, structural analysis, fluid dynamics as well as history, art history, archeology, Turkish language and literature, educational sciences, distance education, communication sciences, graphic design, politics and international relations, law, behavioral sciences, dentistry, economics, business administration, finance, social policy and work relations, fine arts, foreign languages and literature, linguistics.

IAUD is a peer-reviewed journal which is published four times a year. Accepted articles are those which contain original theoretical and/or experimental studies as well as educational explanations related to fixed reference values.

IAUD Editorial Board is authorized to decide whether or not to accept articles through international peer-reviews. 


\section{General Rules}

1. The language of the articles is Turkish and English

2. If there is an institution that supports the study, the last word of the article title should be placed on $\left(^{*}\right)$ and the information on the same page as the footnote should be given.

3. Manuscripts should not exceed 12.000 words including bibliography and annexes.

4. Articles should be organized according to the APA reference system. Please make sure that the references in the text are in the references

\section{Writing Rules}

\section{- Page Layout}

Margins: up 3,5; down 2,5; left 2,5; right $2 \mathrm{~cm}$ with $170 \mathrm{~mm} \mathrm{X} 240 \mathrm{~mm}$ over all text space.

\section{- Type of Font}

Times New Roman style should be used. Turkish Abstract English Abstract should be in $11 \mathrm{pt}$, main text should be $10 \mathrm{pt}$. Text, Turkish-English abstract and the sources used should be justify. Text should be written using single line spacing, 1 line spacing between paragraphs should be left.

\section{- Headlines}

The manuscript should be composed of main headings and sub-headings.

\section{- Main Title}

Times New Roman character, using capital letters, bold and must be in Microsoft Word format in 14-pt format. Author name, abbreviations, author ORCID number and e-mail addresses should be written with two lines of space after the title and the name of the author should be written in $11 \mathrm{pt}$ font size.

\section{- Abstract (ÖZ)}

The text should be written in 11-pt font in Times New Roman font style and in a single paragraph in Microsoft Word format. Must not exceed 300 words and should be bold, $11 \mathrm{pt}$. Keywords should be in italic, bold type and $11 \mathrm{pt}$. At least three, maximum five key words should be written with the first letter and the other letters with small letters. In abstract (ÖZ), subject of the article, research method and result should be given. 


\section{- Abstract}

Abstract title should be written with two lines of space after Turkish keywords. Times New Roman should be in bold, 11 pt, justified, and in single word Microsoft Word format using capital letters. Should not exceed 600 words and abstract should be bold, 11 pt. and all text should be written in Microsoft Word format in Times New Roman style. Keywords in abstract should be in italic, bold type and $11 \mathrm{pt}$. At least three, maximum five key words should be written with the first letter and the other letters with small letters. In abstract, subject of the article, research method and result should be given.

\section{- Sections}

Section subtitles (INTRODUCTION, CONCEPTUAL FRAME, LITERATURE SCANNING, RESEARCH METHODOLOGY, FINDINGS, CONCLUSION, etc), which are formed according to the content of the article, should be all uppercase, $11 \mathrm{pt}$ and bold, and they should be typed without numbering.

\section{- Main Text}

Subtitles should be written in $11 \mathrm{pt}$, bold and capital letters and the text should be in 11 pt., Times New Roman style in Microsoft Word format. Articles should be written in a single column, justified, and in a single space between paragraphs. The subtitle of the first section should start with a line space after the keywords and there should be no spaces in the following paragraphs. Article length must not exceed 20 pages with shapes and figures

\section{- Tables, Figures, Graphics and Pictures}

If the tables, figures, graphics and pictures used in the text are not originally created by the author (s), they can be used in the text by showing "source". Tables, figures, graphics and pictures should be placed to fit the text and the headings should be written in 11 font size and centered. Tables and graphs used in the text should be listed as Table 1., Table 2. / Chart 1., Chart 2. etc. and so on. Table numbers and titles should be written before the table. Figures, graphics and pictures of the numbers and the headers (figure, graphic and picture) then the bottom of the Figure 1., Figure 2. / Picture 1., Picture 2. etc. should be written as ordered. The first letters of the words used in the tables, figures, graphics and image titles should be initials large and the others are small.

\section{- Conclusion}

- The title should be written in bold, $11 \mathrm{pt}$, capital letters and text in $11 \mathrm{pt}$. Times New Roman style in Microsoft Word format. 


\section{- In-article Reference Representation}

Reference within the article should be arranged in accordance with the APA rules.

See the APA reference guidelines: https://www.citefast.com/styleguide. php? style $=$ APA\&sec $=$ form

Reference to single authored sources: (At1lgan, 2015: 28), (At1lgan, 2015: 28-32)

Reference to sources with two authors: (Atılgan \& Demir, 2015: 28), (Atılgan \& Demir, 2015: 28-32)

When reference is made to sources with five authors for the first time: (At1lgan, Demir, Çelik, Savaş \& Yıldırım, 2015: 28)

When reference is made to sources with five authors for a second time or more: (At1lgan vd., 2015: 28)

When references to resources with more than five authors are made for the first time: (Atılgan, Demir, Çelik, Savaş, Yıldırım.....Işık, 2015: 28)

Reference to sources with more than five authors for the second time or more times: (Atılgan vd., 2015: 28)

When reference is made from the Internet: (Mills, 2012)

\section{- Bibliography}

Reference within the article should be arranged in accordance with the APA rules.

See the APA reference guidelines: https://www.citefast.com/styleguide. php? style $=$ APA\&sec $=$ form

\section{Single Author Book}

Tuncer, D. (1992). Dă̆ıtım Kanalları Sistemi. Ankara: Gazi Yayınları.

\section{Two Authors Book}

Turgut, M. F. \& Y. Baykul. (1992). Ölçekleme Teknikleri. Ankara: ÖSYM Yayınlar1.,

\section{Edited Book}

Theberge, J. (Ed.). (1968). Economics of Trade and Development. New York: John Wiley.

\section{Translation Book}

Morgan, L.H. (2015). Eski Toplum. (Oskay,Ü. Çev.), İstanbul: İnkılap Yayınevi. 


\section{Part of Book}

Ünlüer, A.O. (1988). Boş Zamanı Değerlendirme Açısından Kitle İletişim Araçlarının Ülkemizde Durumu. Demiray, U. (Ed.). Kitle İletişim Araçları ve Boş Zaman.(ss.71-113). Eskişehir: Anadolu Üniversitesi Eğitim Teknolojisi ve Yaygın Eğitim Vakfi.

\section{Published Magazine}

Engin, B. H. (2016). Markalaşma Kavramı Çerçevesinde Marka Ederi. Öneri Dergisi. 12 (46): 277-294.

\section{Electronic Magazine}

Yengin, D. \& Algül, A. (2018). Küreselleşme Bağlamında Sanal Gerçeklik Kullanımı. Turkish Online Journal of Design, Art and Communication-TOJDAC. 10 (2): 155-126. doi: 10.7456/10902100.

\section{Published Journal}

Kumcu. E. (2006, 11 Aralık). Büyüme yavaşlama sinyali veriyor. Hürriyet Gazetesi. s.9.

\section{Electronic Journal}

Mills, S. (2012, 16 Ekim). How Twitter is winning the 2012 US election. The Guardian. https:/www.theguardian.com/commentisfree/2012/oct/16/twitterwinning-2012-us-election (Erişim tarihi: 10 Temmuz 2018).

\section{Dissertation}

Algül, N. (2006). Sanat Tarihinde Mahmut Akok. Marmara Üniversitesi Türkiyat Araştırmaları Enstitüsü Türk Sanatı Anabilim Dalı Yayınlanmamış Doktora Tezi, İstanbul.

\section{Web Page}

Yavuz, E. (2018, 7 Kasım). Zaman ve İnsan Üzerine. https://dusunbil.com/ zaman-ve-insan-uzerine. adresinden alındı. (Erişim tarihi: 10 Temmuz 2018).

\section{Report}

Taymaz, E. (2018). Dijital Teknolojiler ve Ekonomik Büyüme Raporu. (TÜSİAD-T/2018,10-600). 


\section{Electronic Report}

Taymaz, E. (2018). Dijital Teknolojiler ve Ekonomik Büyüme Raporu. (TÜSIAD-T/2018,10-600). https:/www.tusiad.org/tr/yayinlar/raporlar/ item/10130-dijital-teknolojiler-ve-ekonomik-buyume-raporu. (Erişim tarihi: 10 Temmuz 2018).

\section{Contact Information: \\ Journal of İstanbul Aydın University \\ Editorial Board, Doç. Dr. Deniz YENĞíN}

- The articles should be sent to the below e-mail address.

İstanbul Aydın University, Faculty of Communication

Beşyol Mahallesi, İnönü Caddesi, No: 38

Sefaköy, Küçükçekmece/İstanbul

Tel: (212) 4441428

Web: http://iaud.aydin.edu.tr

E-mail: denizyengin@aydin.edu.tr 

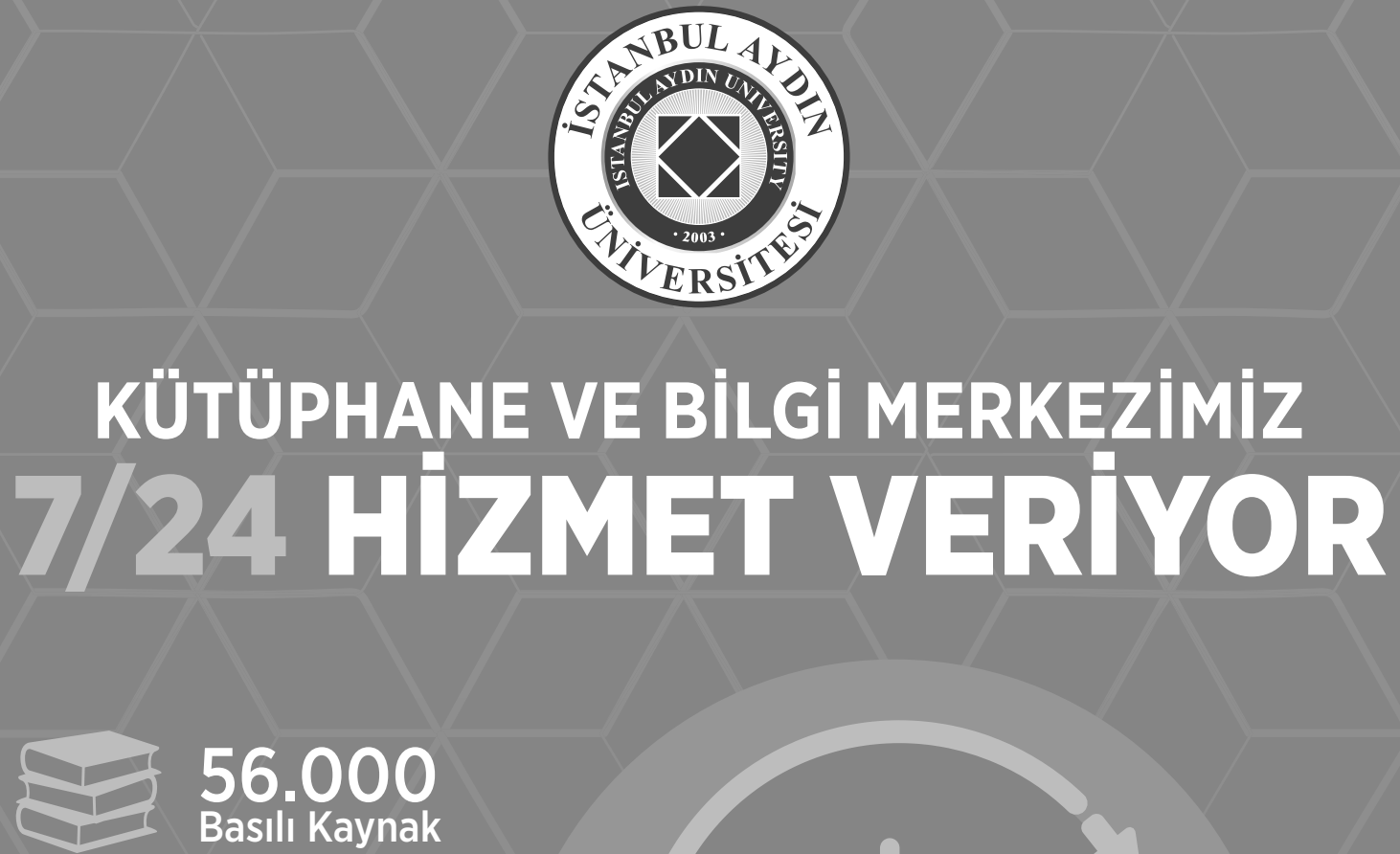

56.000

Basılı Kaynak

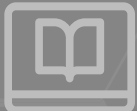

1.000 .000

E-Kaynak

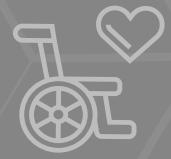

Engelsiz Kütüphane
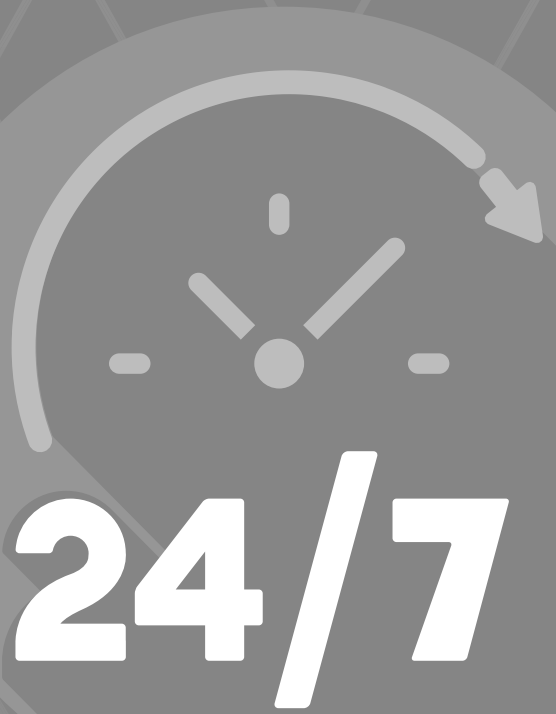

s.d) Uygulamalar

Kütüphane 7/24/365 gün hep açık

75.000 aylık kullanıcı

- Mimarlık ve Mühendislik Fakültesi için çizim salonları

Kafeterya 